\title{
قراءة في الهندسة العامة للدستور المغربي الجديد (II. )
}

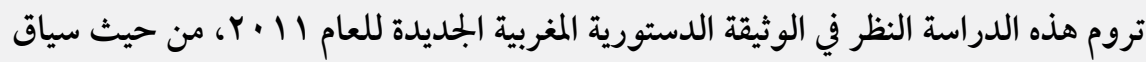

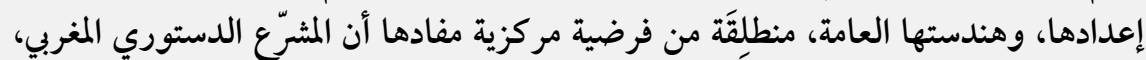

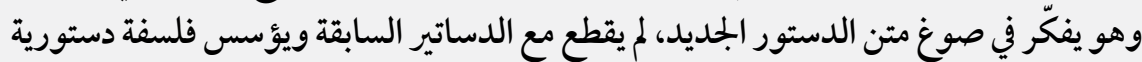

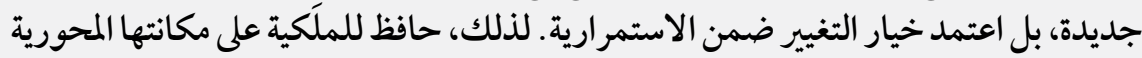

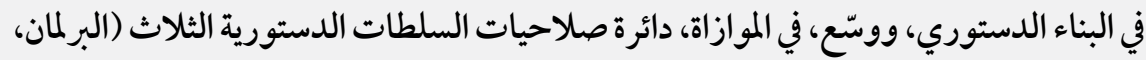

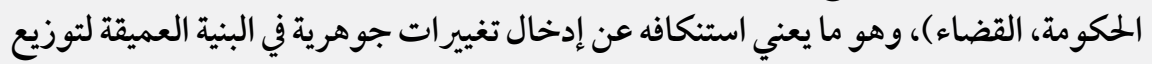

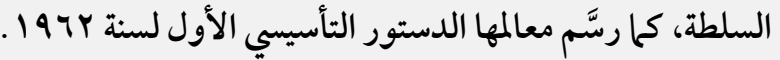

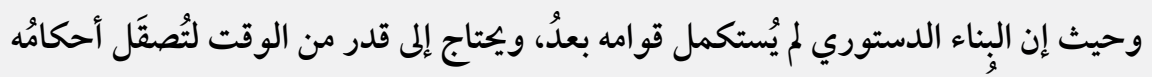

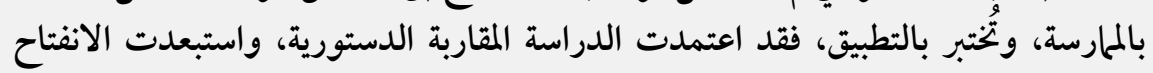

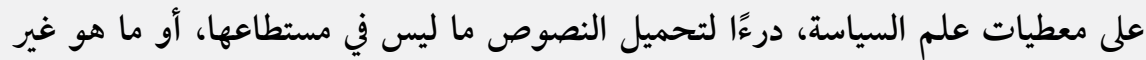
مطلوب منها.

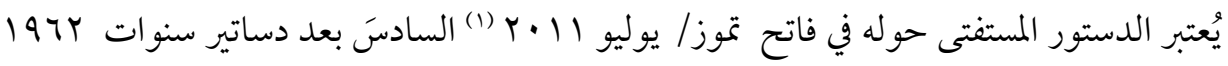

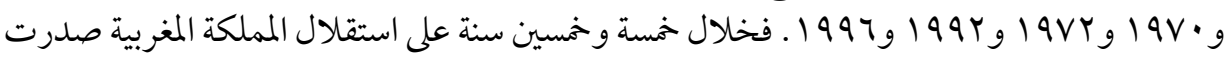
ست وثائق دستورية، أي بمعدل دستور و احد على رأس كل تسع سنوات، وهو متوسط له دلالته من الناحيتين

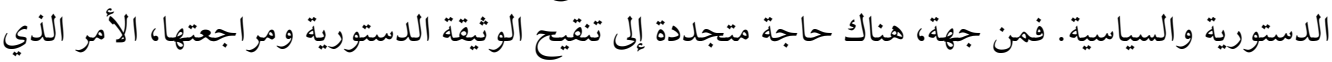

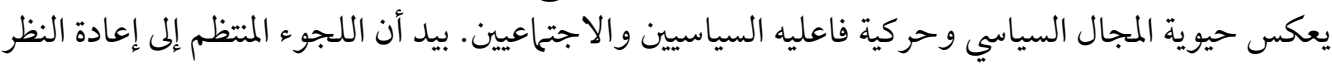

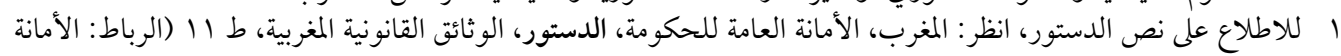




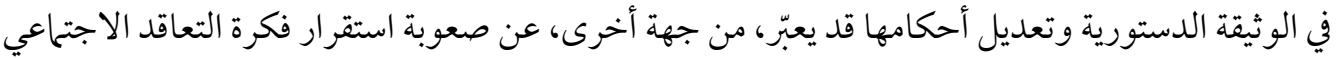

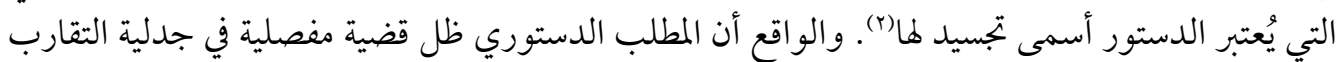

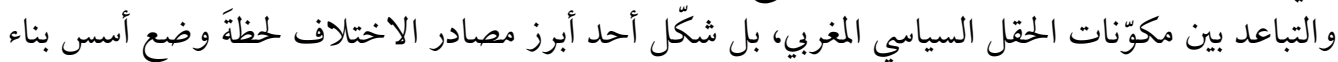

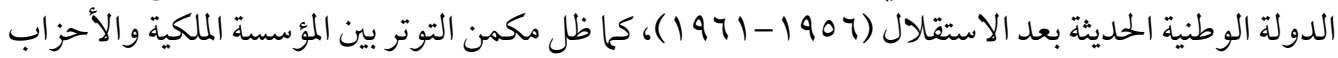

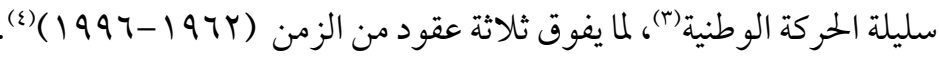

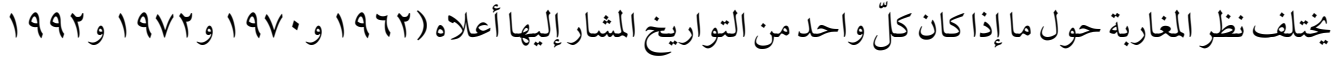

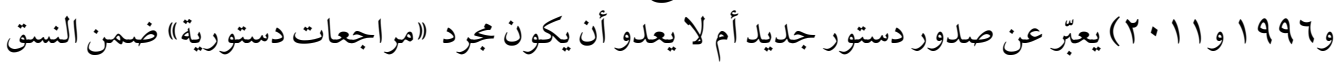

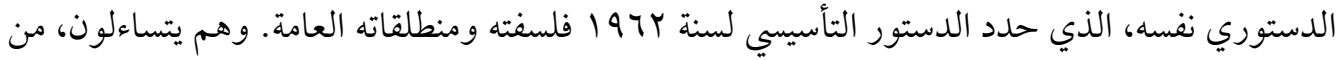

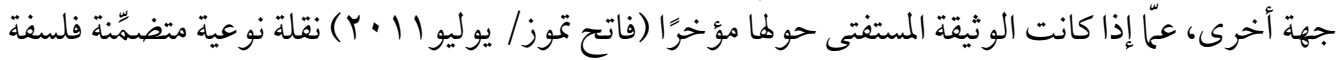

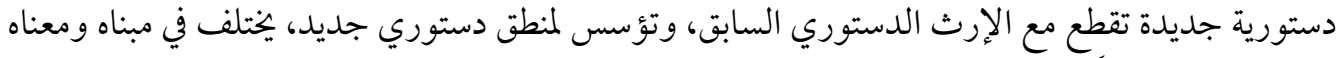

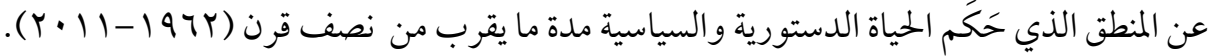
تنطلق الورقة من أن المغرب شهد دستورين اثنين، هما: الدستور التأسيسي لسنة بأب 97 ا، و والوثيقة المو افَق عليها

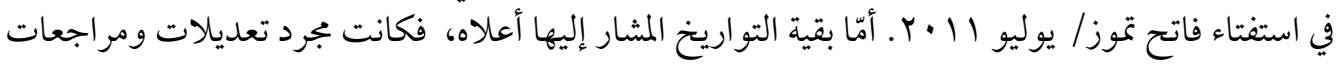

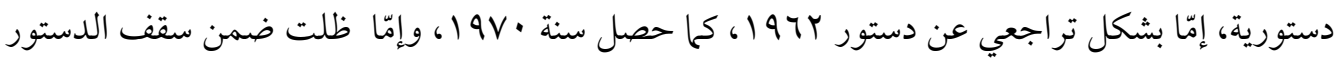

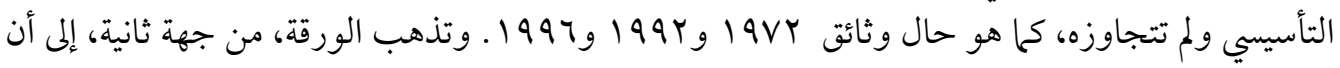

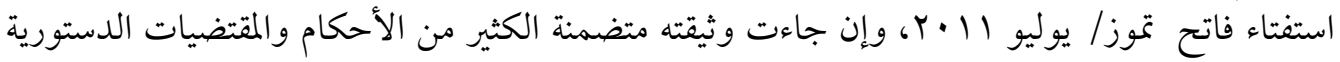

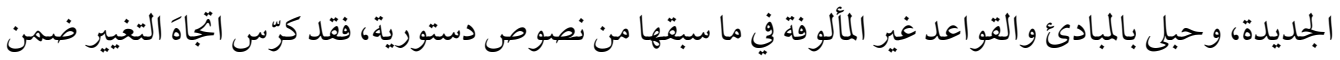

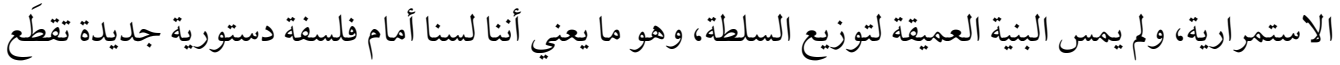

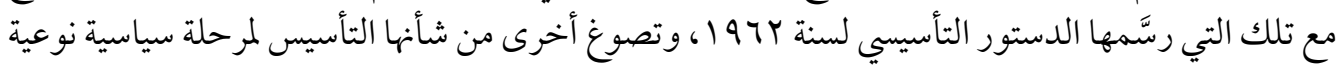

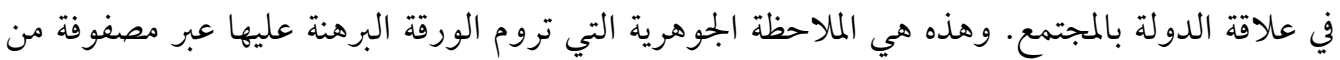

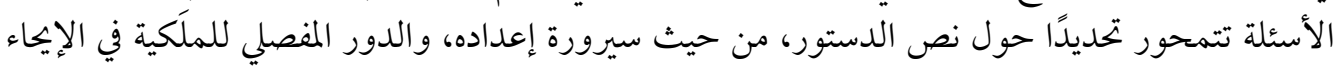
بفلسفته ورسم خريطة طريق صوغه، وذلك قبل الانتقال إلى التدقيق في قسمات هندسته العامة. تُنبّه الدراسة القارئ الكريم إلى أن مقصدها الأساس يروم تحليل مفاصل البناء الدستوري في الوثيقة الدستورية

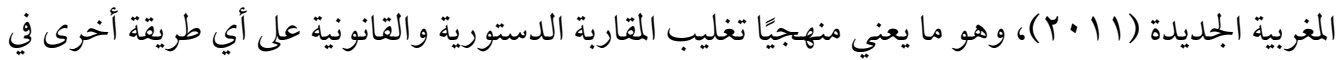

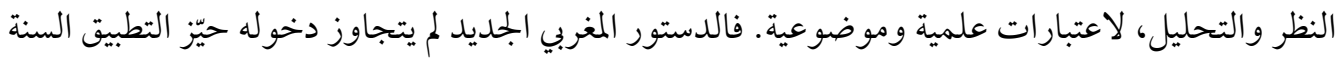

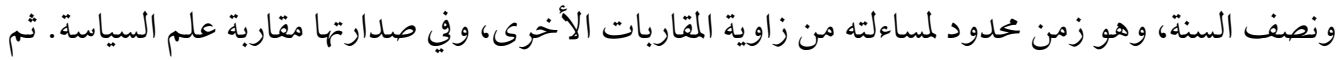

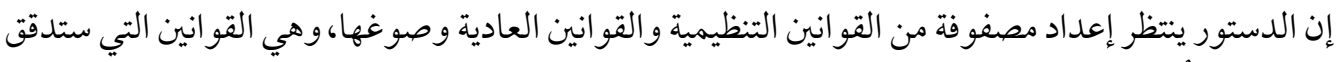

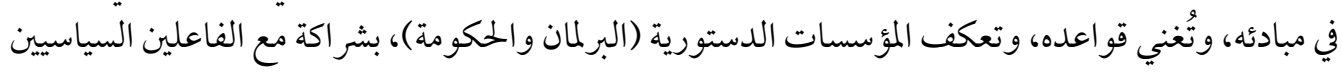

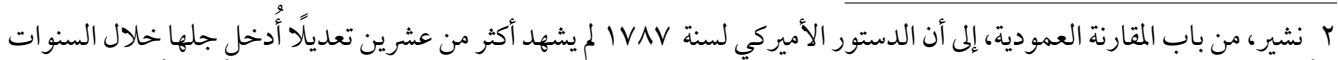

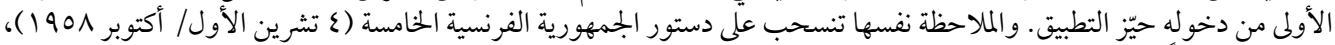

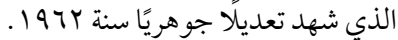

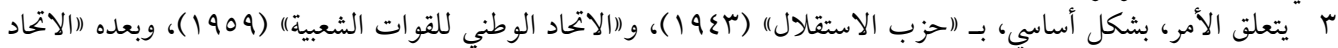

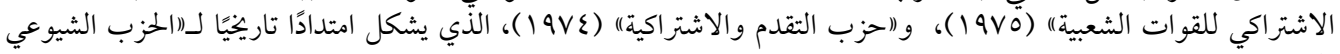

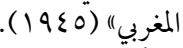

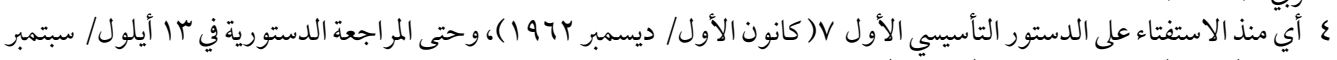
(997 1997، التي حظيت بها يشبه إجماع الشعبّ المغربي. 
والاجتماعيين (أحزاب ونقابات وجمعيات) على إنجازه، لاسيا أن الفصل السادس و الثمانين من الدستور ألزم

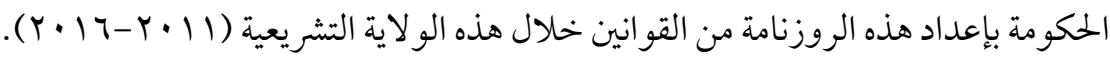

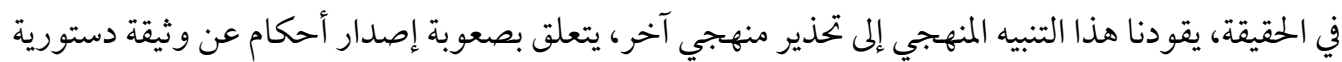

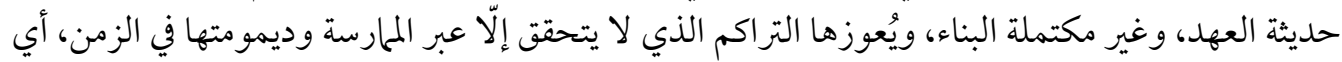

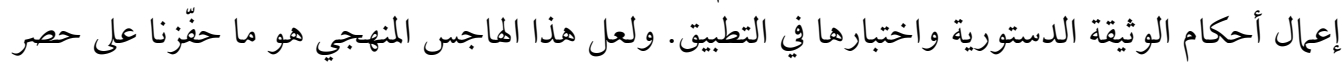

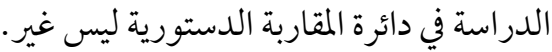

\section{الملَكية والإصلاح الدستوري}

لم يكن واضحًا حتى لحظة إعلان الخطاب الملكي في 9 آذار / مارس / 1 • ب أن المغرب مقبل على إعداد دستور جديد، وإنْ ظل مطلب الإصلاح الدستوري والسياسي يتردد في خطب الأحس الحزاب السياسية، تارة بشكل

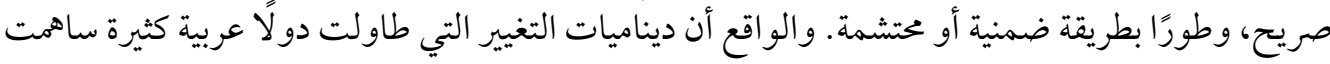

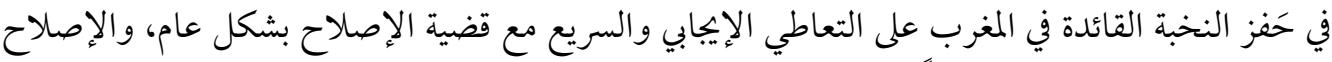

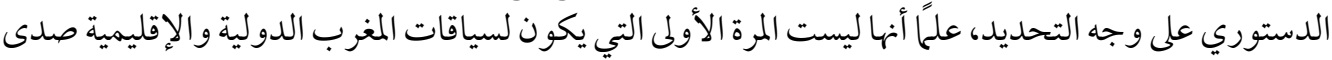

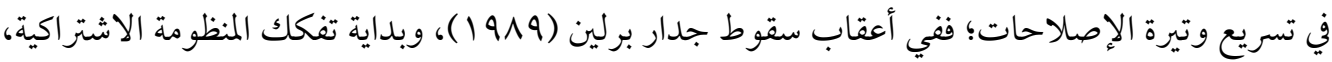

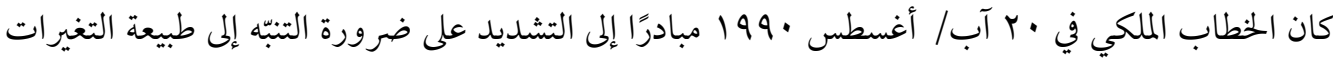

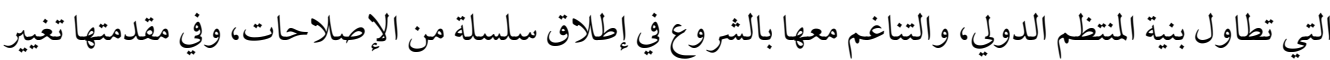

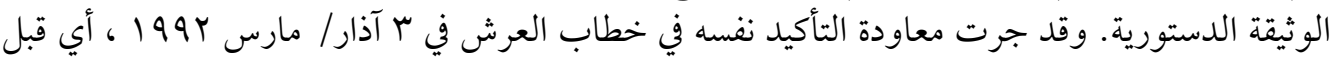

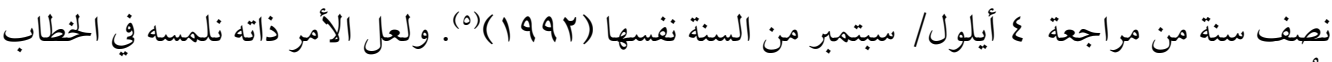

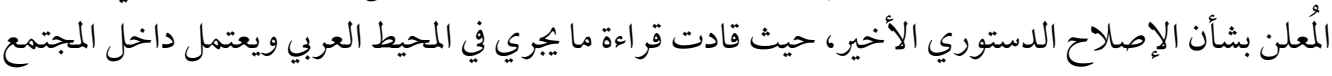
المغربي إلى الاستباق إلى إعلان وضع دستور جديد يروم التغيير ضمن الإستوري الاستمر ارية.

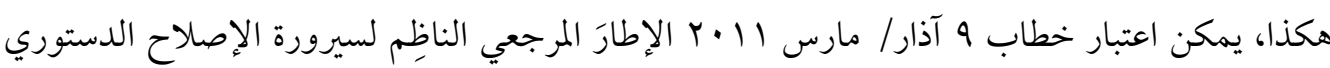

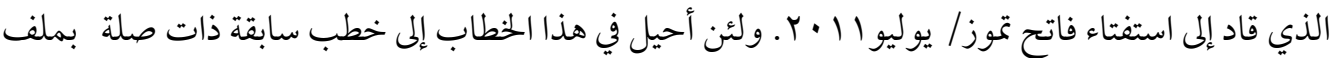

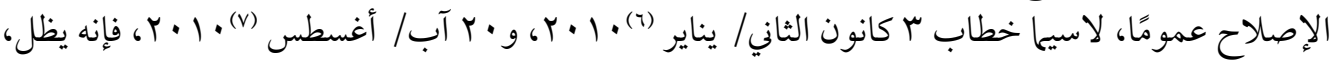

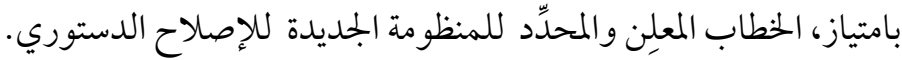
ورد الخطاب الملككي مكثفًا وختصرًا على مستوى صو غه، كما جاء و اضحًا في رؤيته لطبيعة الإصلاح، ومضامينه،

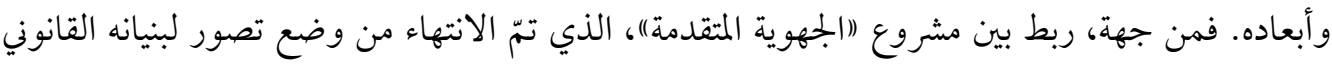

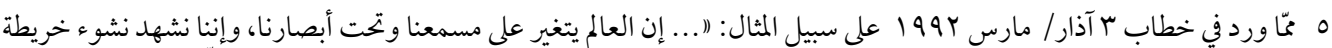

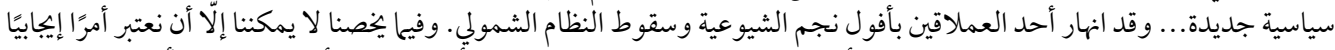

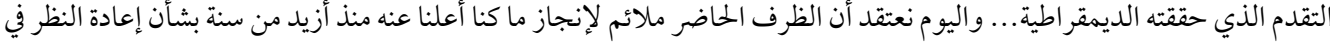

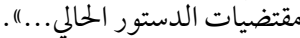

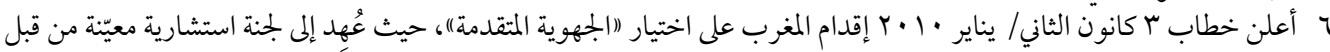

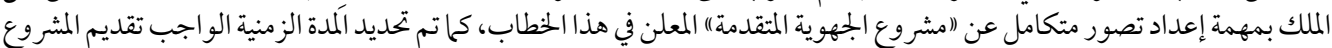

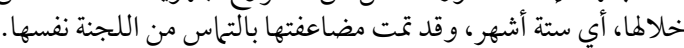

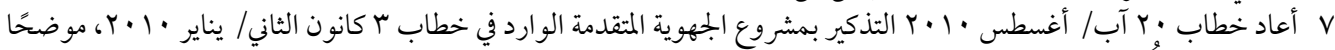

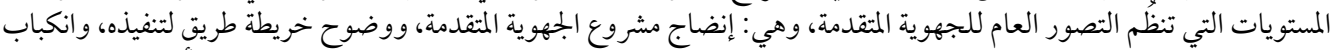

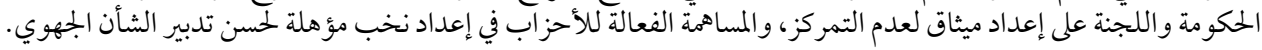




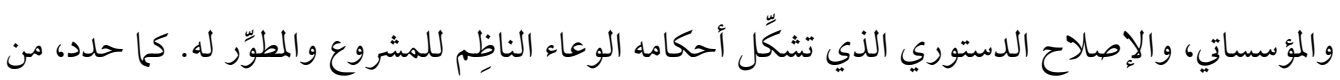

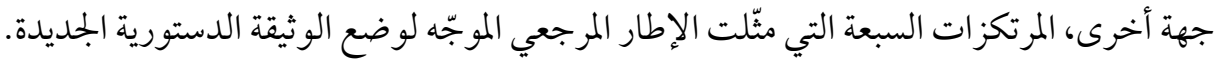

\section{الجهوية المتقدمة مدخل للإصلاح}

يُعتبر مشروع ((الجهوية المتقدمة)، ، المُعلَن في خطاب التنصيب في ب كانون الثاني/ يناير • 1 • ب، أحد المحاور الأساسية

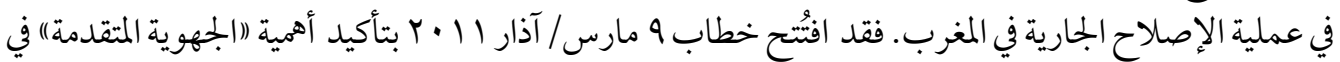

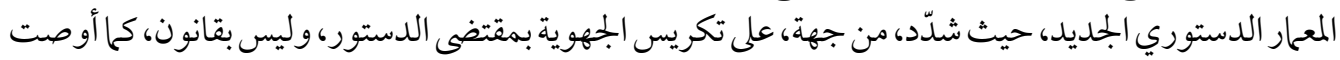

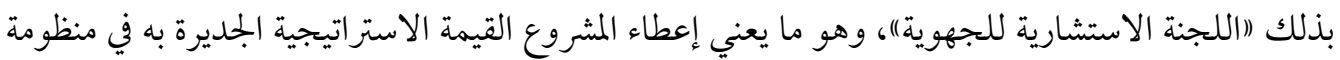

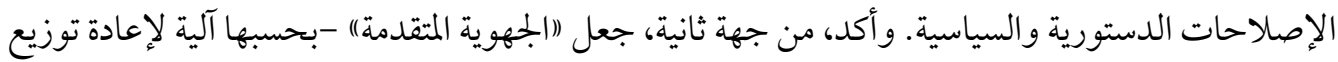

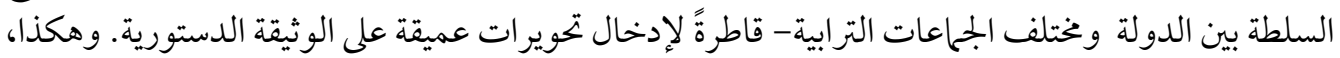

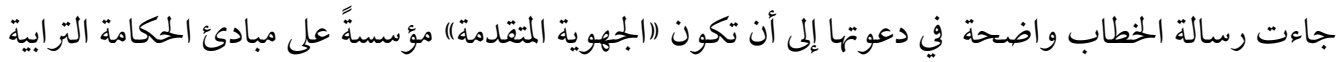

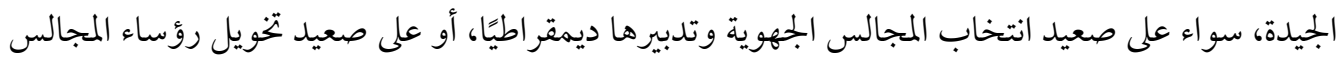

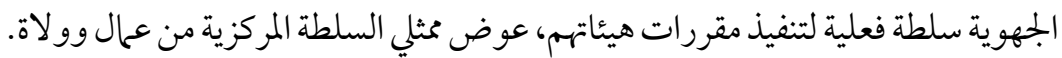

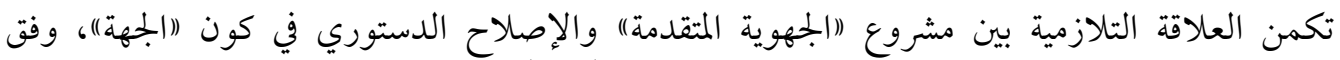

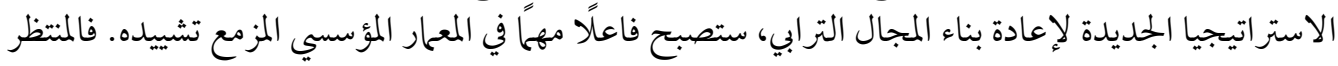

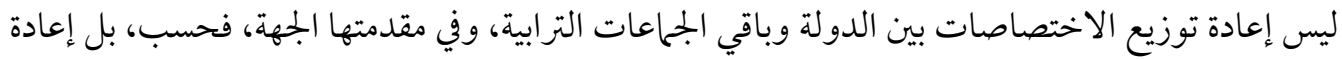

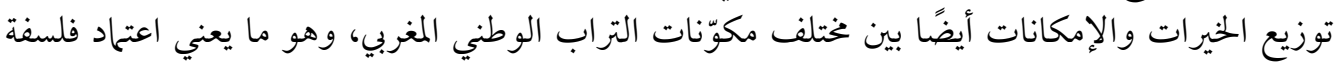

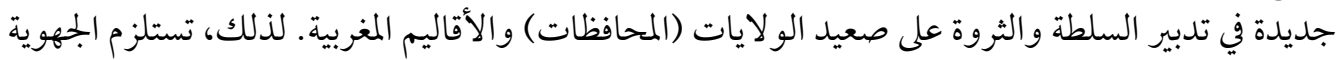

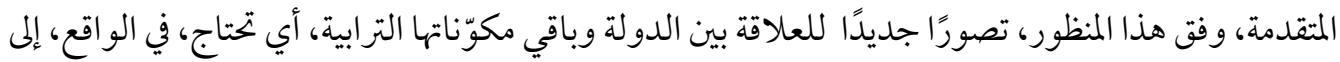

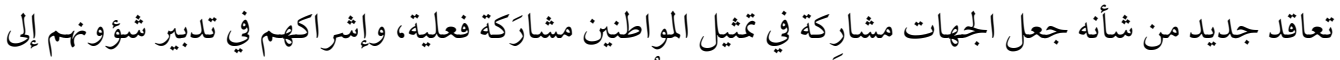

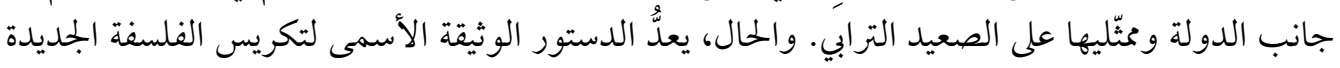
لعلاقة الدولة بباقي مكوّناتها الترابية.

\section{مرتكزات الإصلاح}

تضمَّن خطاب 9 مارس/ آذار 1 | • ب المرتكز ات المرجعية الناظِمة للدستور الجمديد، التي حددها في سبعة، وهي

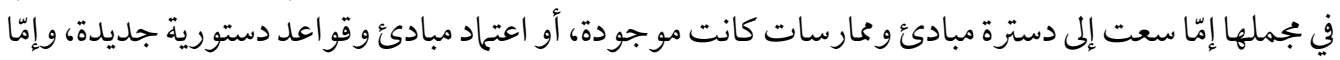

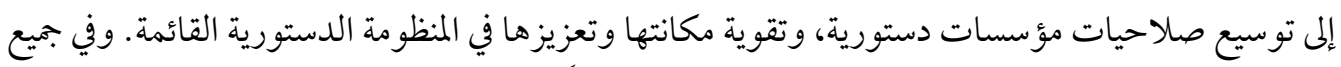

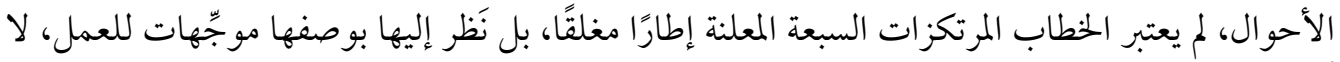

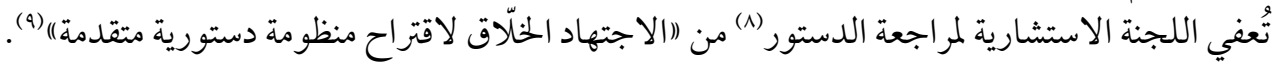

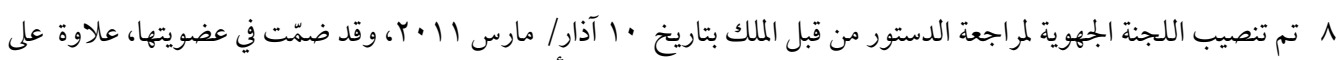

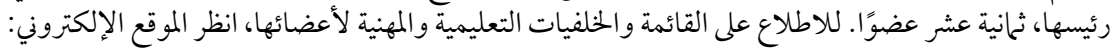
$<$ http://www.diplomatie.ma/arab/larevisondelaconstitution/commissionconsultativederevision/tabid/1773/language- us/ default.aspx $>$ (accessed on 2/2/2013).

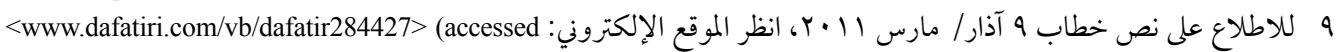




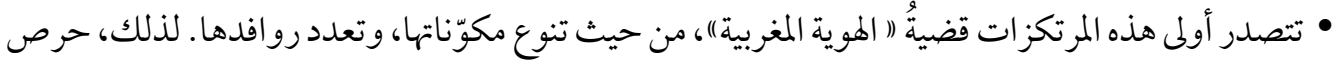

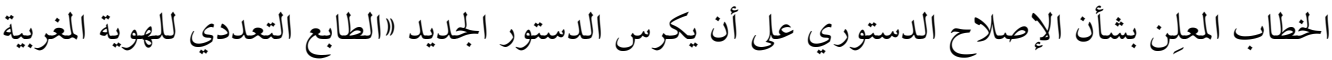

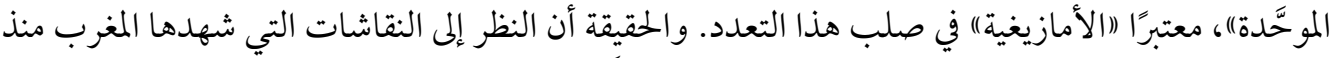

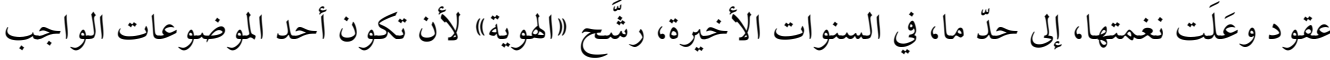

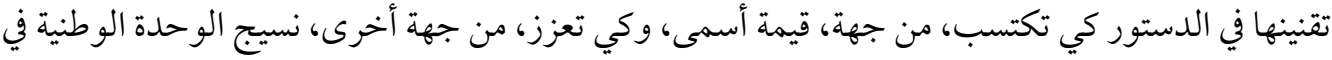

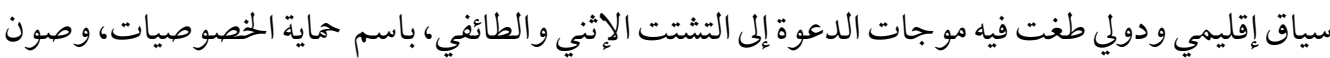
التمايزات العِرقية واللغوية و الثقافية.

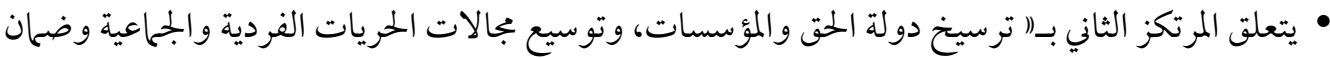

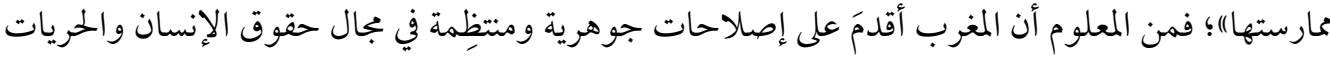

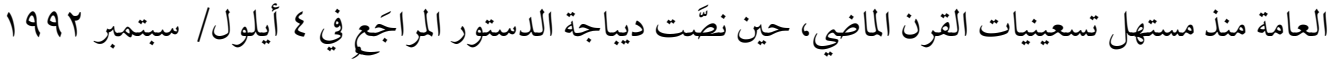

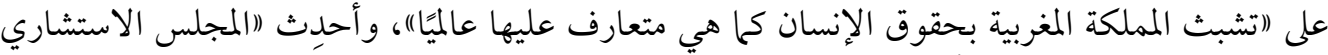

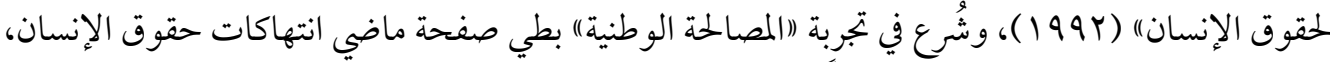

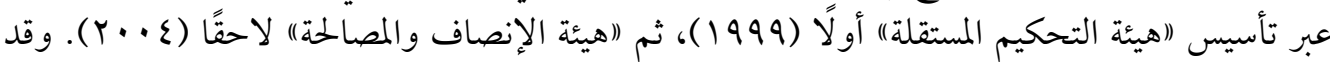

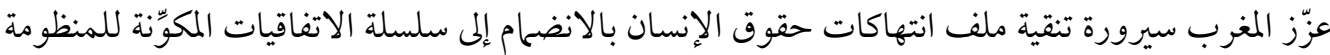

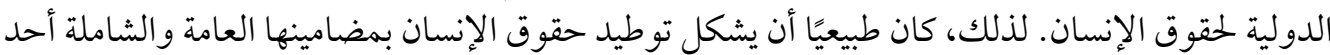

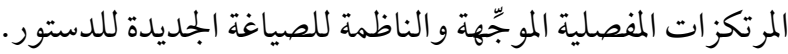
• يخص المرتكزُ الثالث تأكيد استقلال القضاء، وتوطيد سمو الدستور، والمساواة أمام القانون، وهي مبادئ

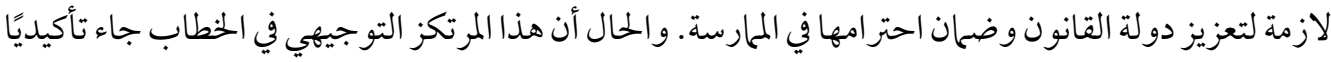

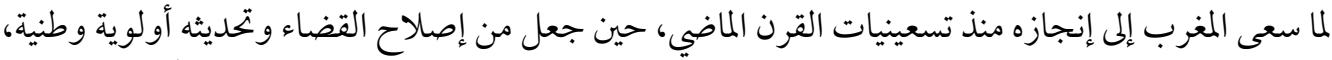

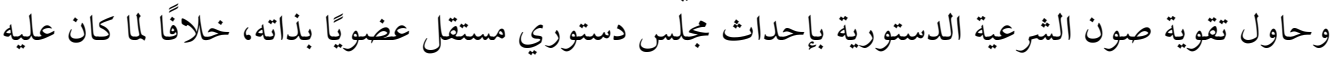

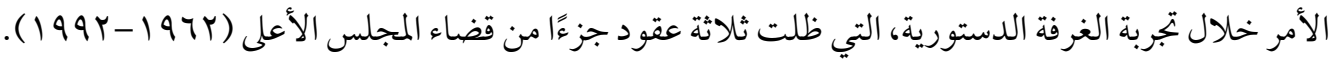

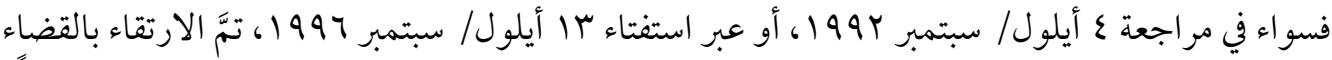

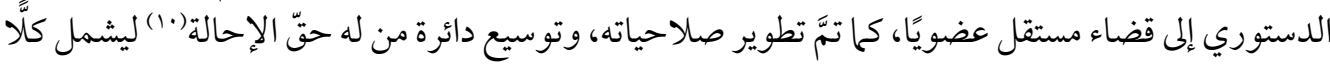

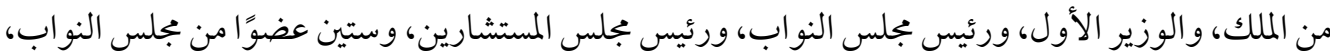

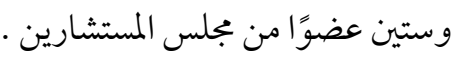

• يتبوأ المرتكز الرابع مكانة خاصة في نص الخطاب، لصلته بأحد أهم المبادئ الدستورية دقة وحساسية،

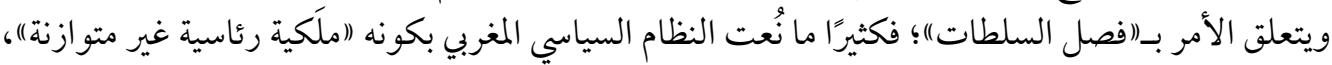

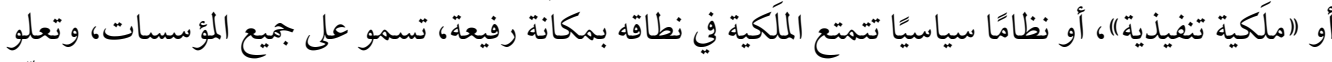

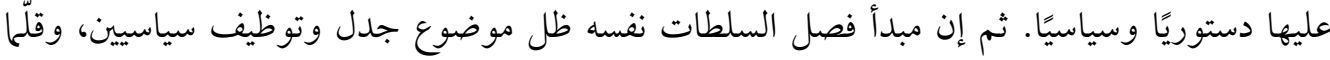
حظي بالتحديد والتوضيح والتقعيد، سواء على مستوى الفقه الدستوري، أو أو على مستوى الخطاب إنساب السياسي.

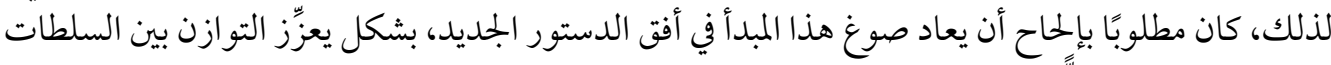

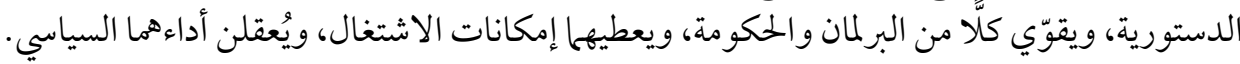

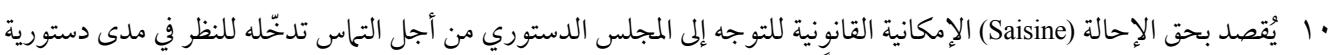

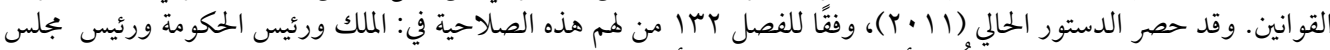

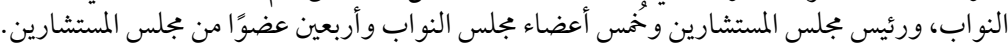


• أولى المرتكز الخامس أهمية خاصة لثقوية دور الأحزاب السياسية، عبر تعميق دمقرطتها، وعقلنة أدائها،

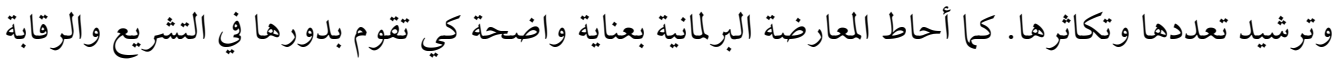

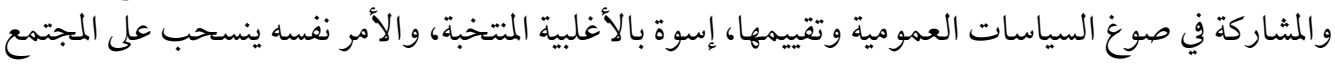
المدني الذي سيصبح بُعدًا له مكانته في أحكام الوثيقة الدستورية الجديدة المبدة.

• يرتبط المرتكز السادس بـ (تخليق الحياة العامة)، و إقامة مبدأ المسؤولية وقاعدة المحاسبة على صعيد ممارسة

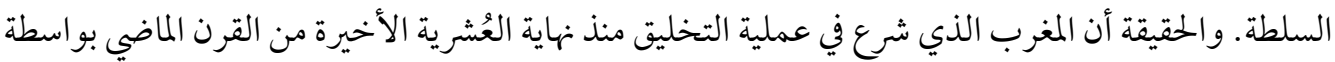

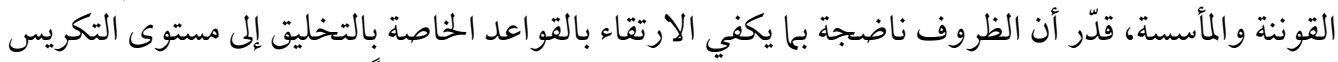

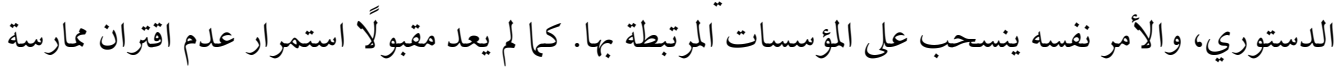
السلطة بالمسؤولية، أو الإفلات من المحاسبة.

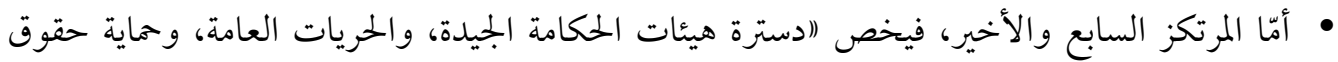

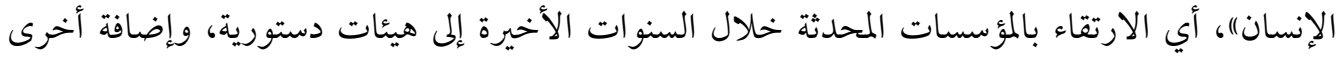

$$
\text { اكتملت ضرورات إنشائها. }
$$

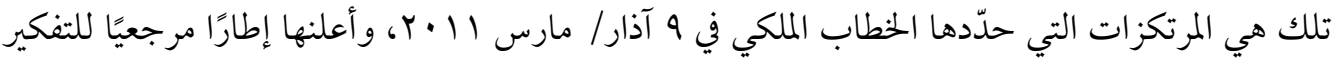

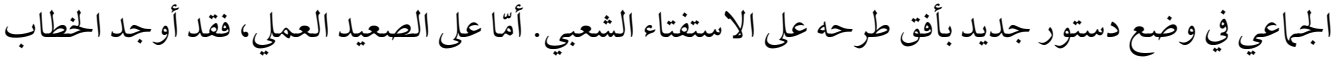

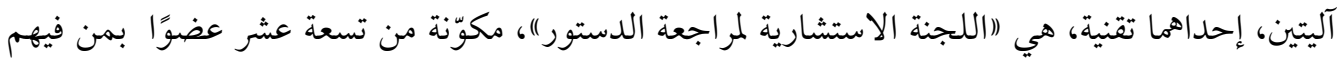

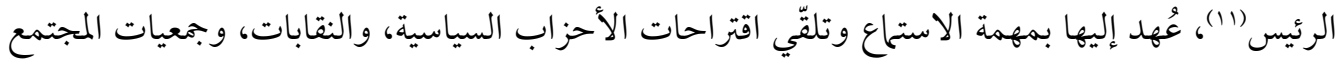

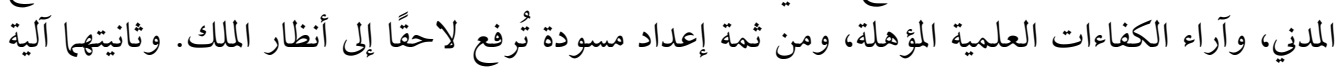

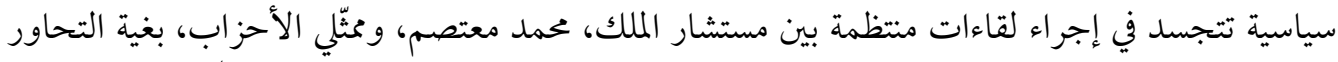

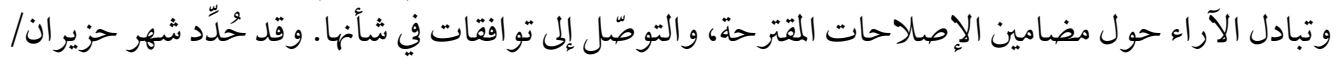

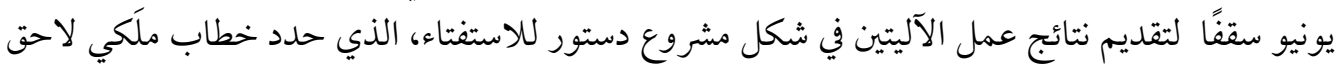

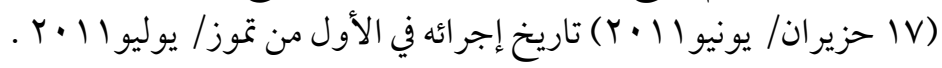

\section{الهندسة الدستورية الجديدة}

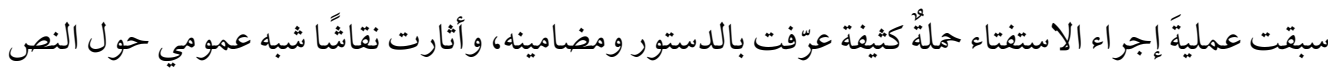

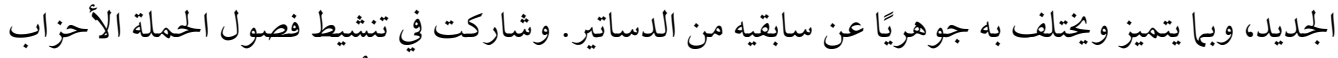

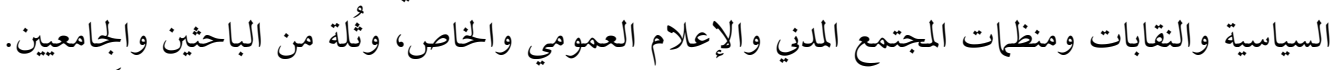

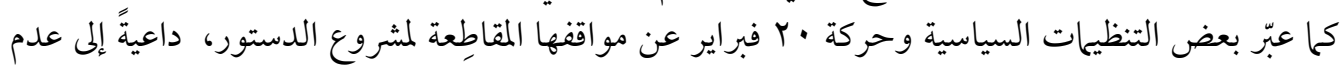

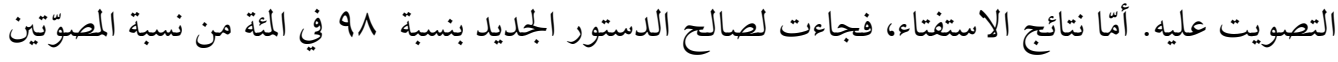

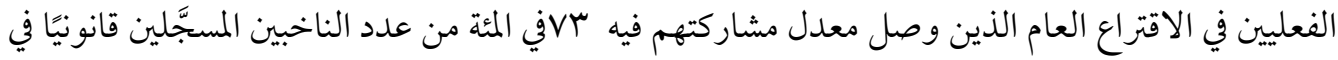

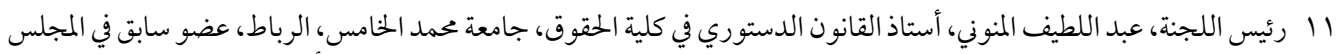

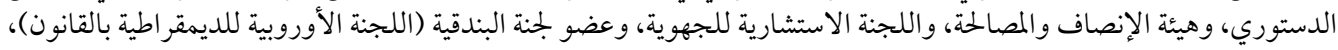

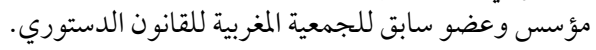


القوائم الانتخابية(rا). فهل نحن أمام هندسة دستورية جديدة، تعكس فلسفة دستورية خختلفة جوهريًا عن

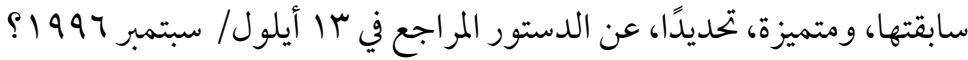
ليست الهندسة الدستورية مجرد تنظيم تقني لأبو اب الدستور، وترتيب فني لمو اده وفصوله، بل هي أكثر من هذا

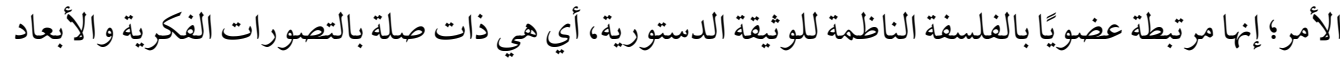

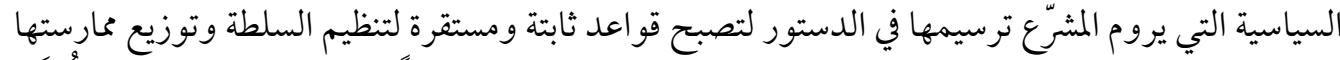

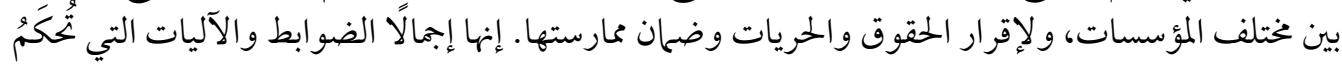

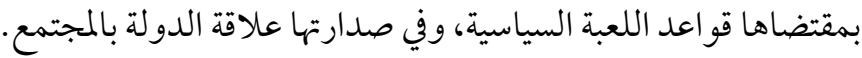

تسمح القراءة الفاحصة للدستور المغربي الجميد، في ضوء التحديد أعلاه، بالقول إنه وُضِع في مبناه ومعناه

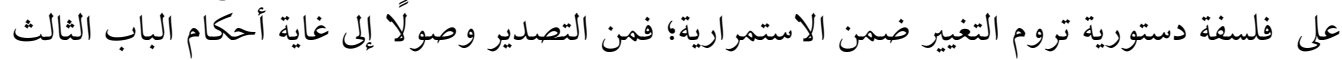

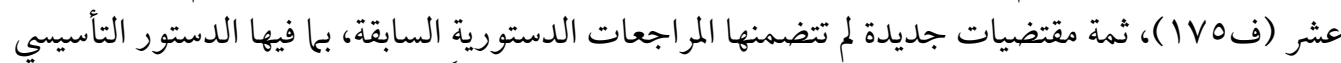

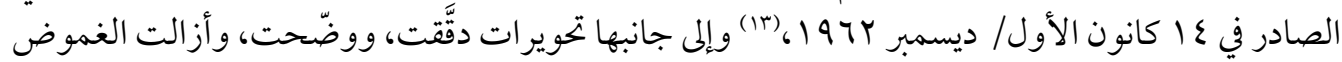

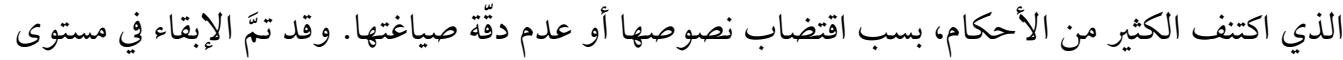

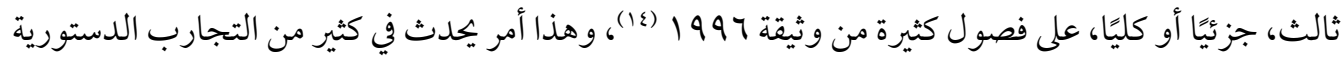

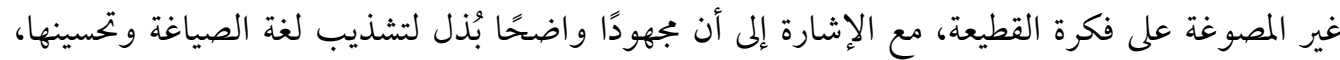

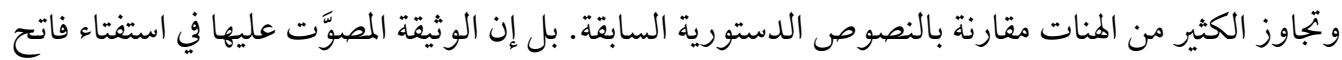

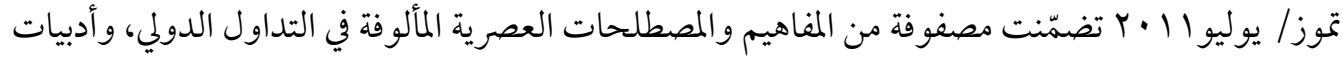

المنظلمات الدولية.

يمكن ملامسة فلسفة التغيير ضمن الاستمرارية في طبيعة التوزيع (الجديد)" للسلطة ضمن هندسة الوثيقة

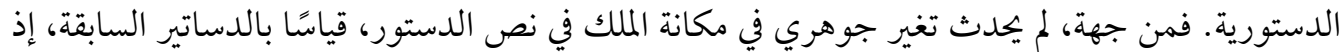

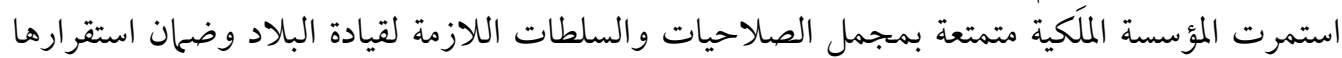

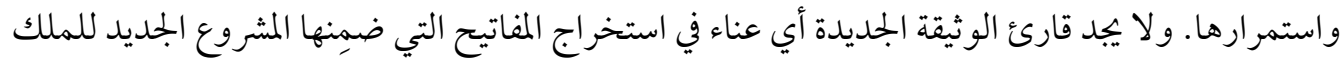

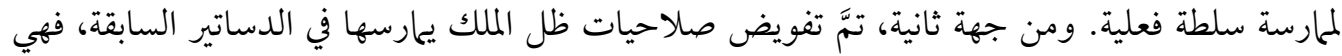

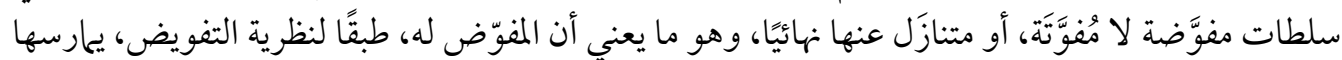

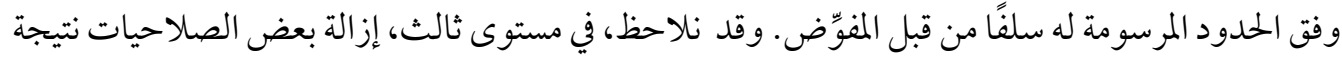

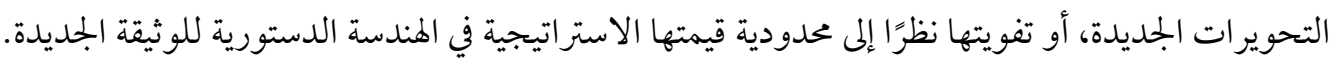

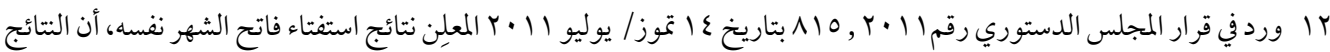

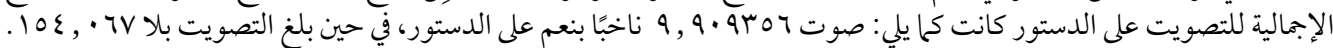

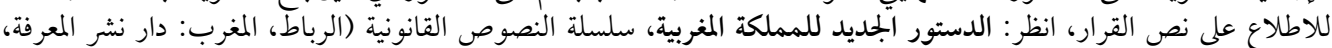

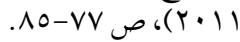

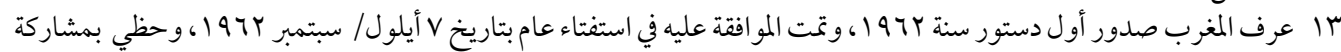

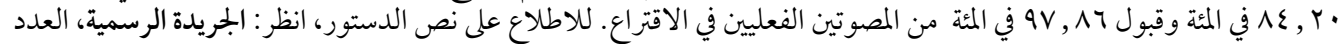

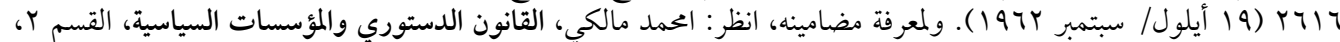

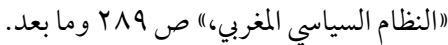

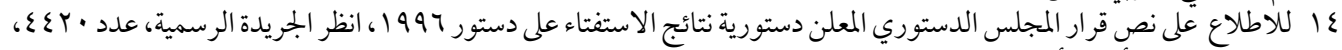

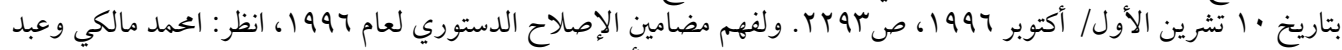

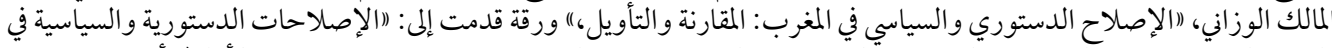

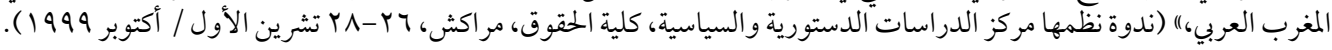




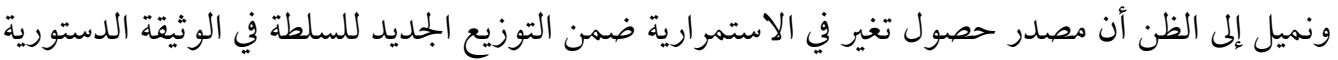

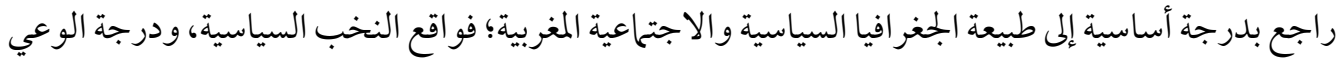

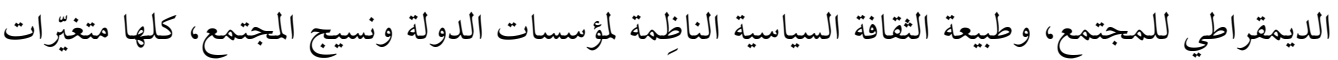

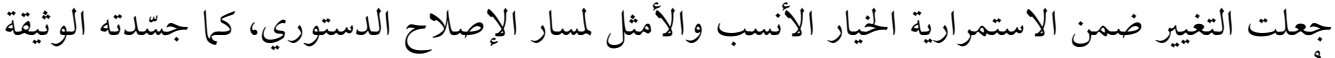

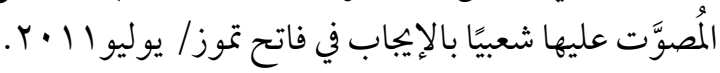

\section{عن مكانة الملَكية}

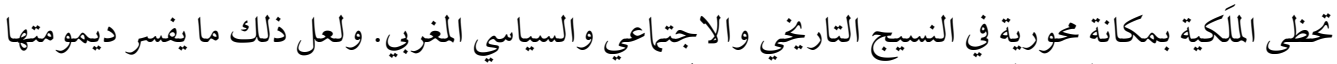

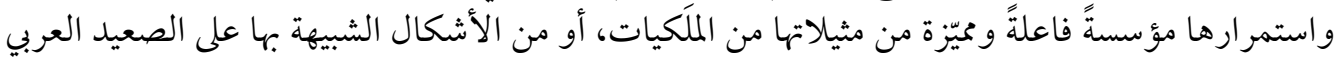

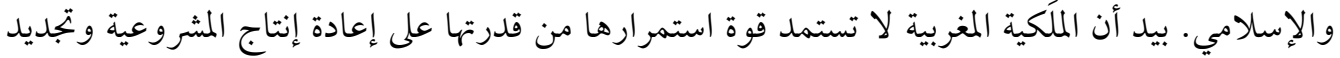

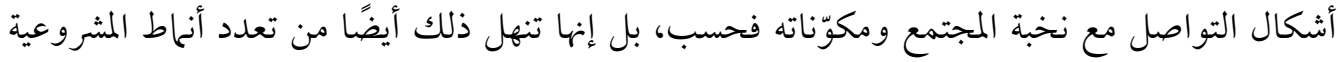

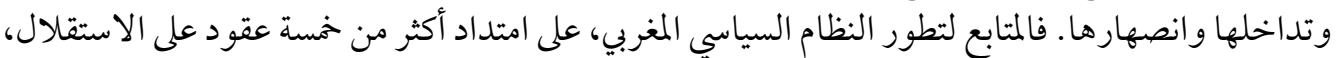

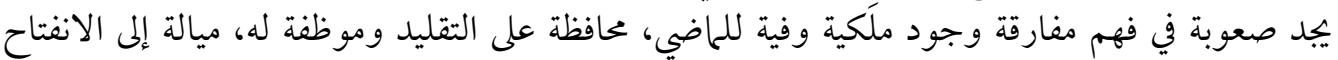

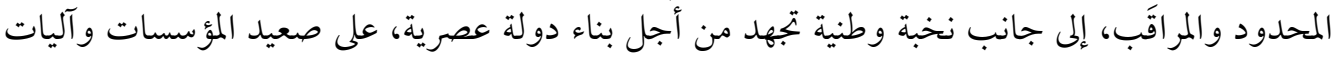

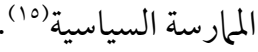

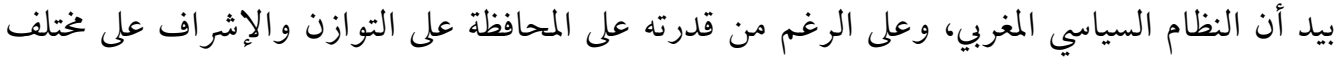

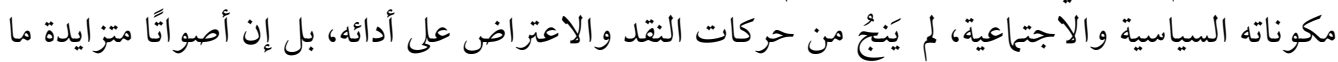

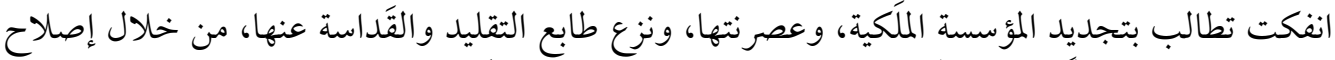

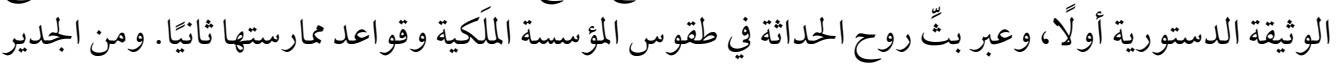

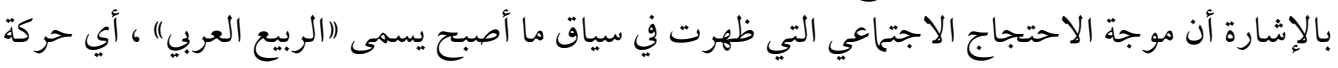

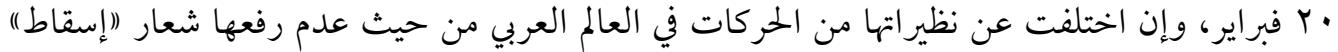

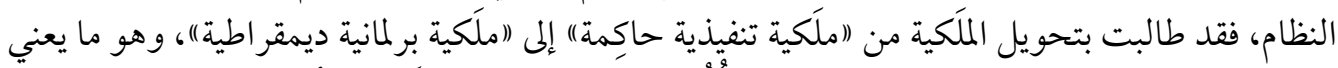

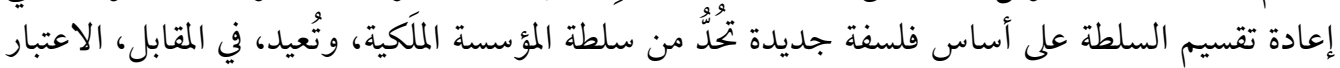

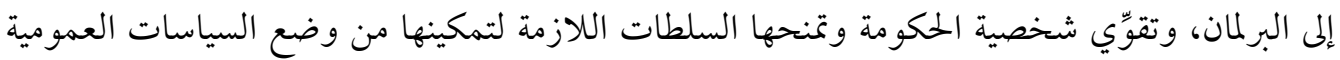
وتنفيذها وتحمّل مسؤولية نتائجها.

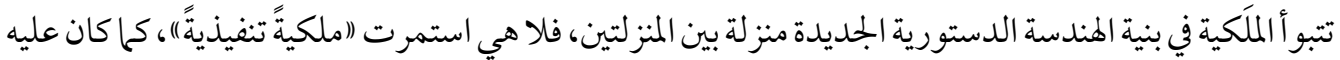

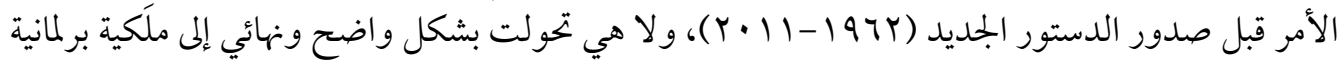

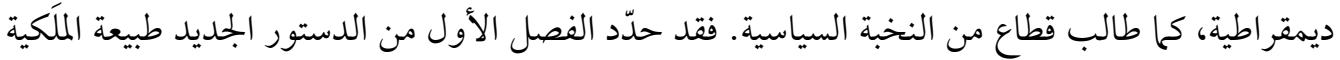

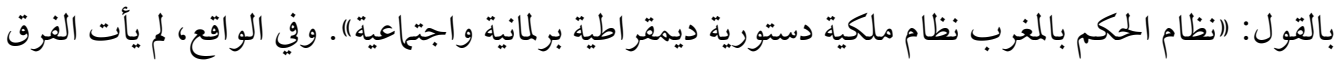

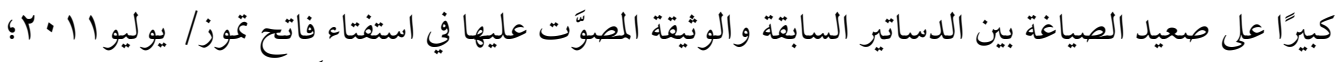

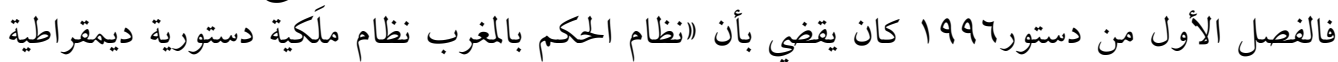

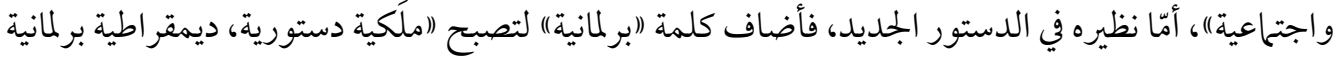

15 Mohamed Tozy, Monarchie et islam politique au Maroc, références académiques, $2^{\mathrm{ème}}$ éd. (Paris : Presses de Sciences po, 1999), p. 15. 
واجتحاعية) . فهل معنى ذلك أننا بصدد تغيّر جوهري في مفهوم الملكية، ومكانتها، وطبيعة علاقتها بالمؤسسات

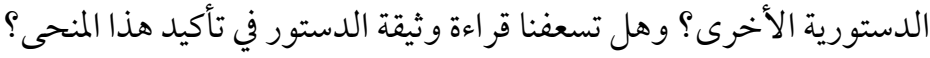
من الجدير بالإشارة أن ثمة فهمًا خاصًا للملَكية في المغرب، يبتعد في معناه ومبناه عن التصورات التي آلت إليها

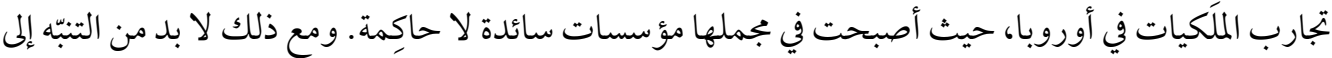

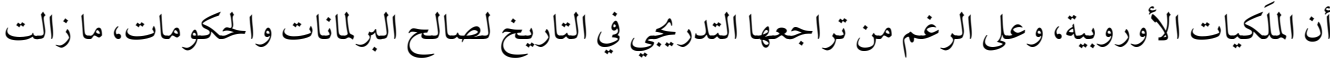

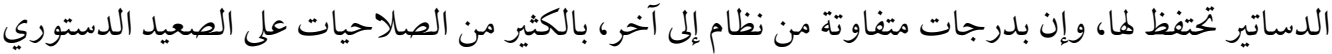

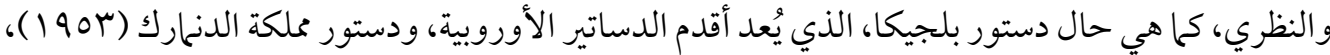

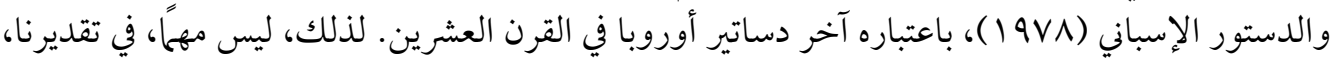

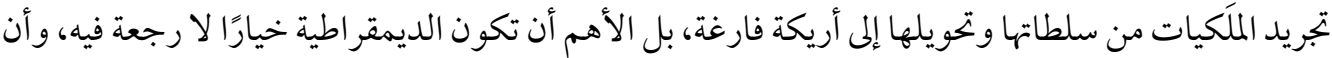

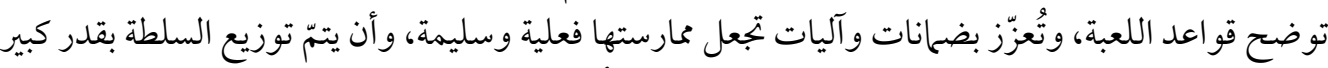

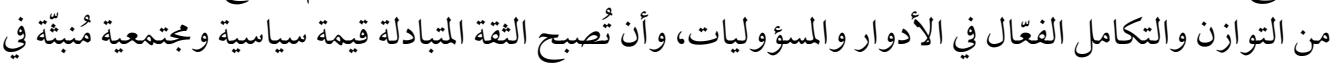

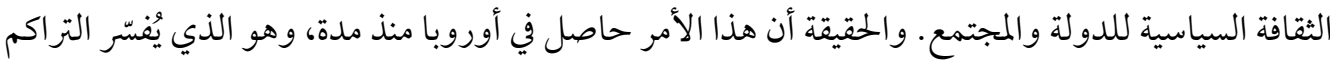
الهائل في فعالية النظم السياسية ونجاعة أداء مؤسساتها الدستورية. استمرت الملككية في المغرب، خلافًا لما تمَّ توضيحه أعلاه، مؤسسة حاكمة، وحاضرة بقوة في المجال السياسي.

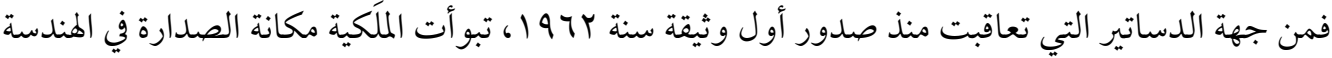

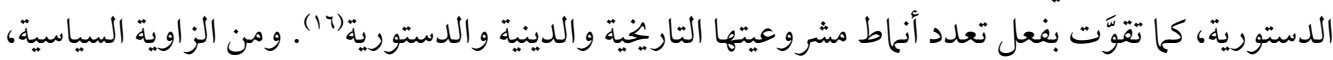

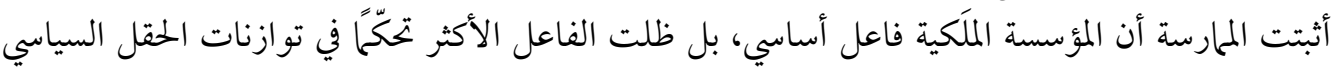

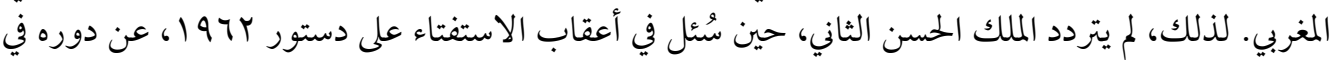

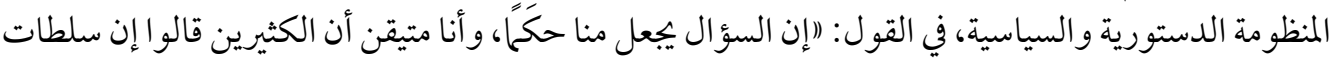

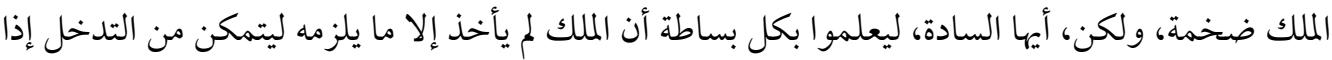

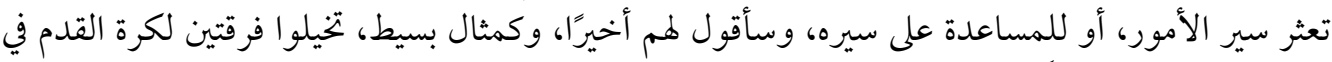

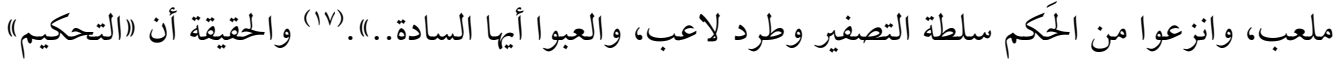
(Arbitrage)

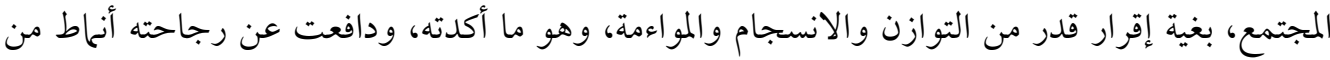

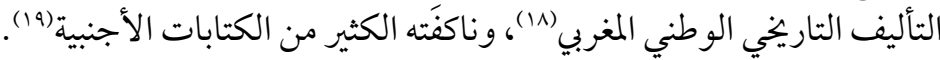

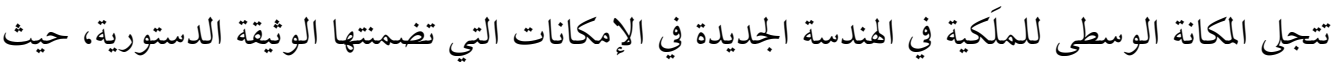

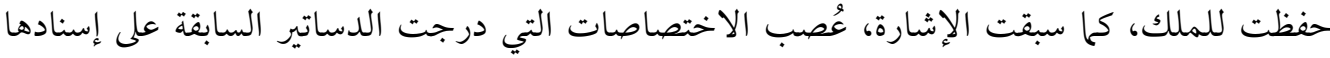
إليه، و أقرّت في الوقت ذاته مبادئ وقواعد جديدة من شأنها تقوية السلطة التشريعية، وتعزيز دور الحكومة الإنة

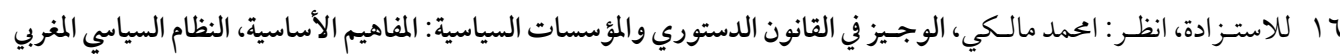

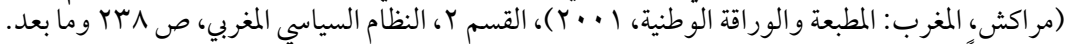

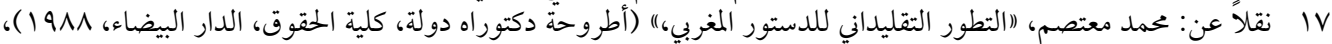
. YAV ص صن

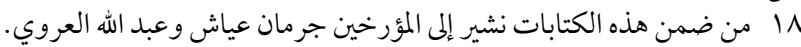

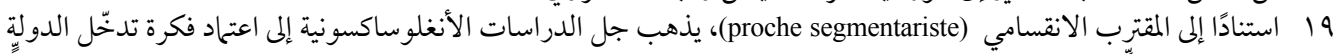

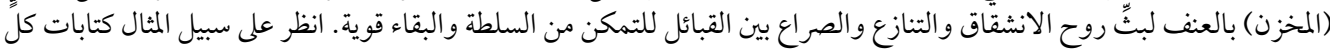




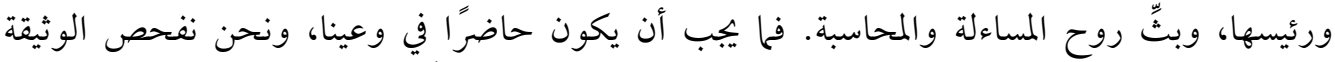

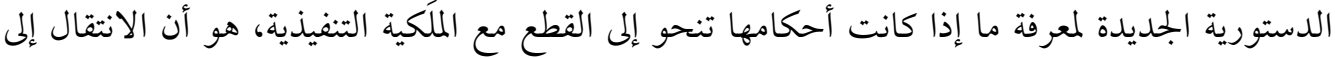

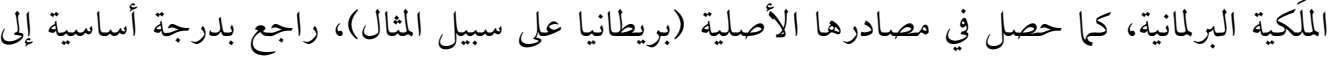

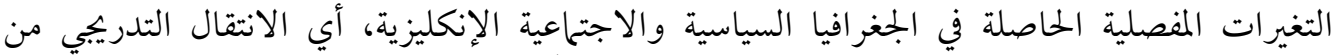

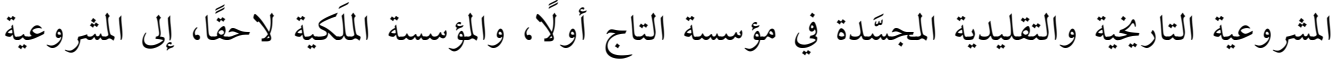

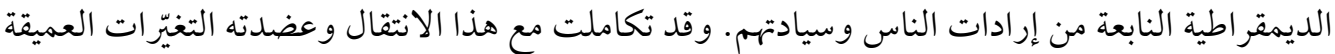

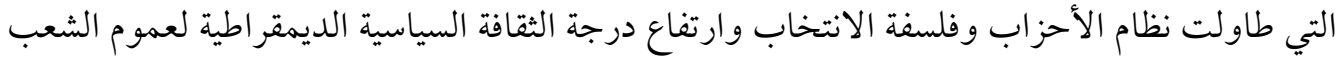

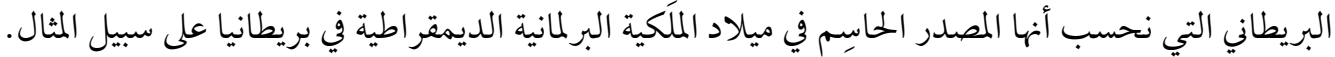

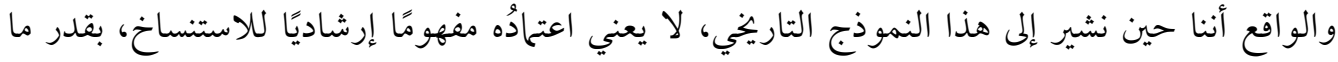

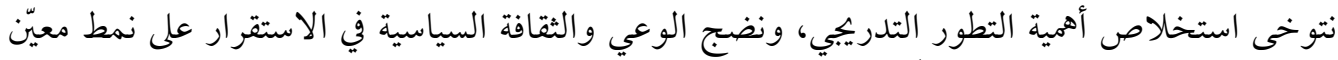

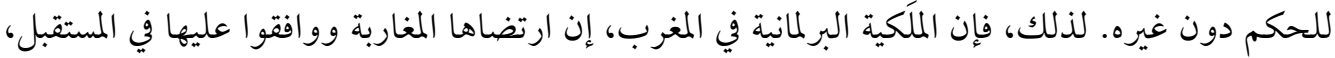

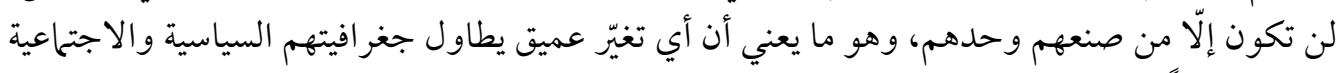

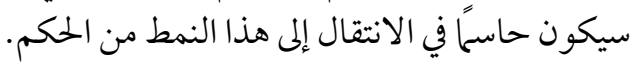

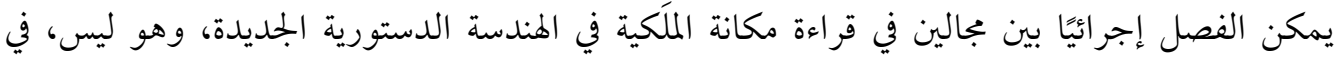

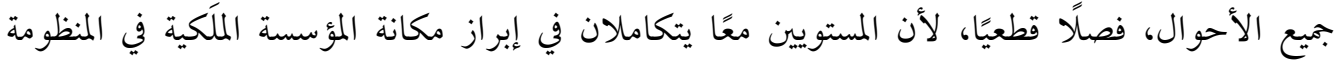

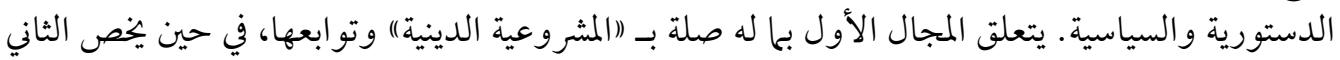

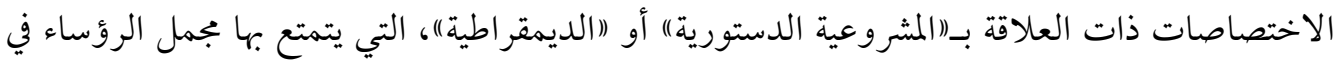
النظم السياسية المعاصرة.

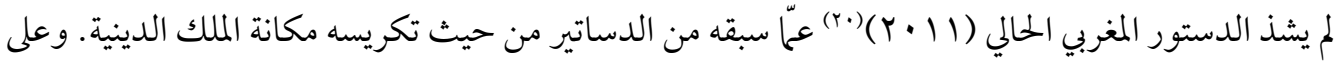

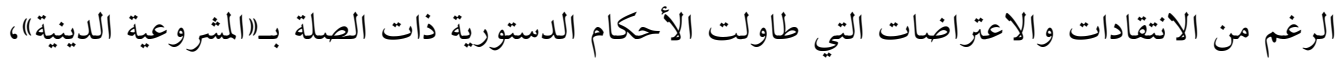

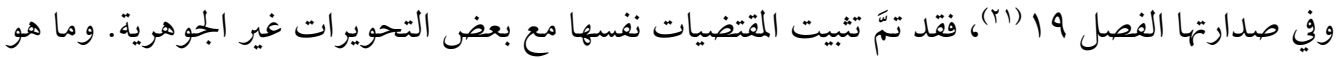

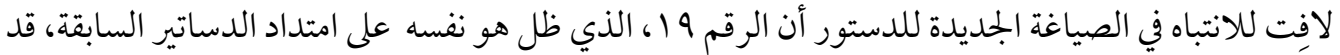

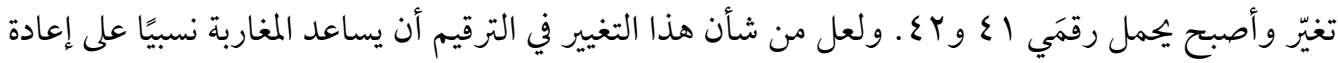

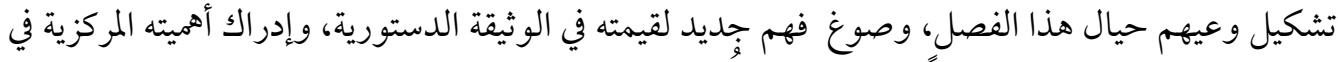

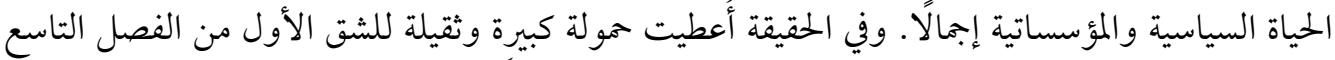

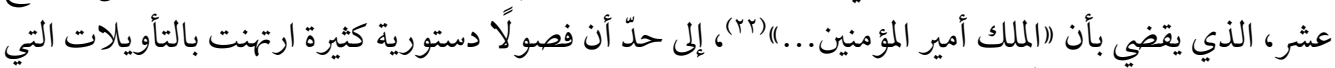

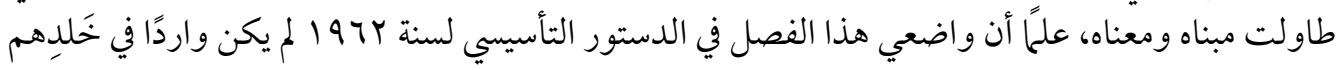

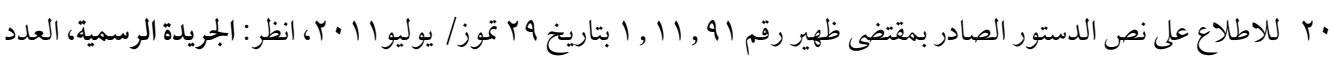

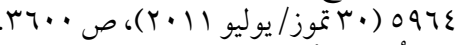

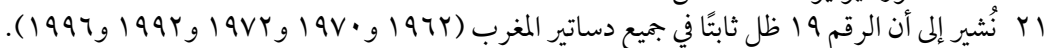

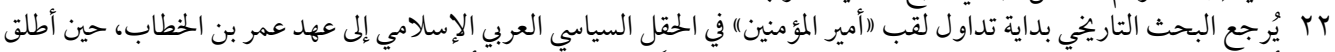

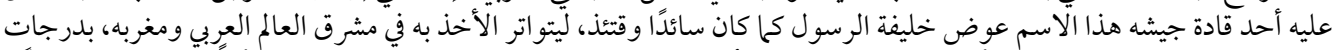

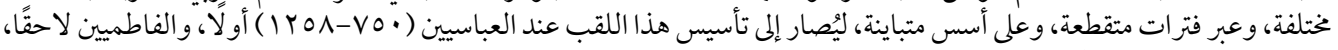

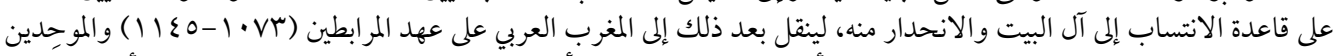

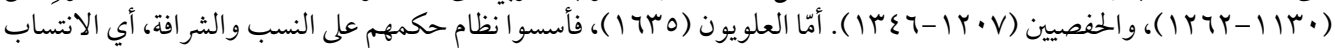




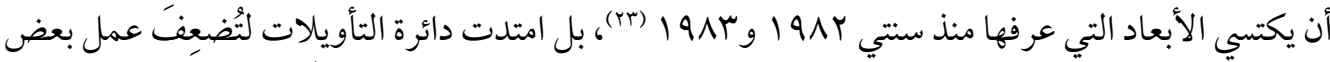

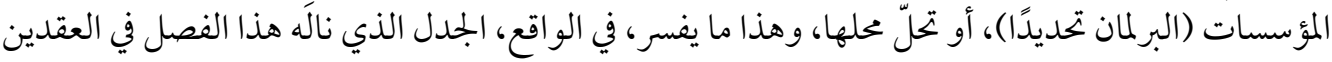

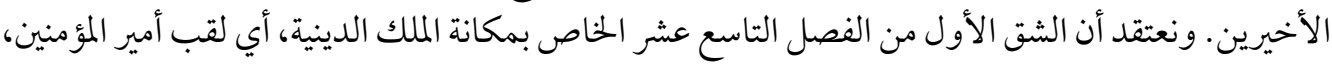

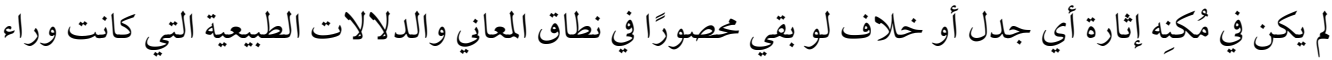

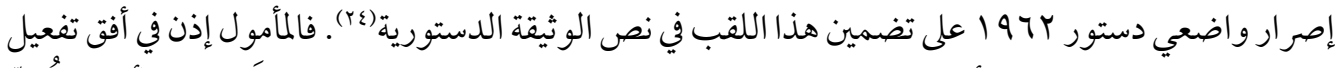

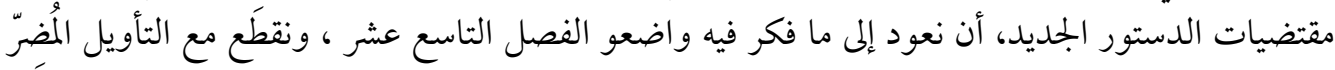

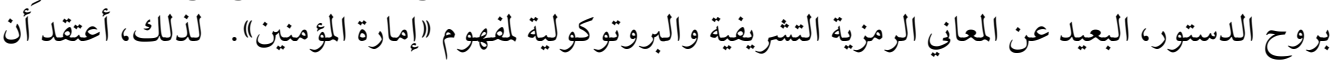

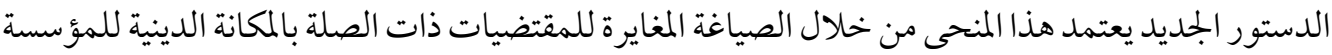

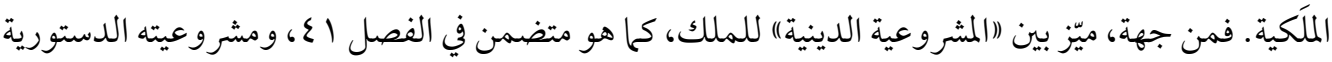

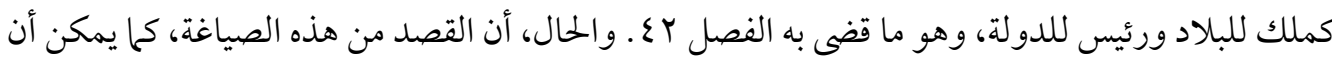

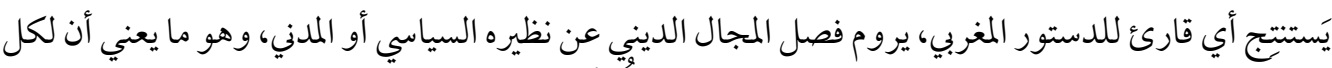

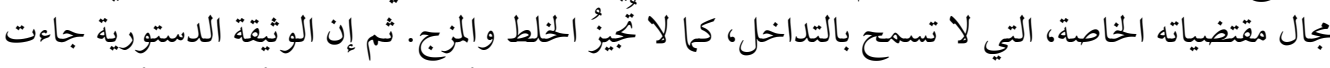

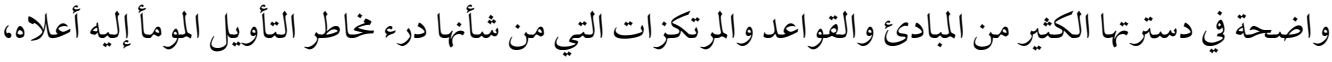

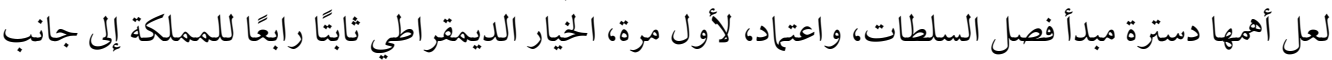

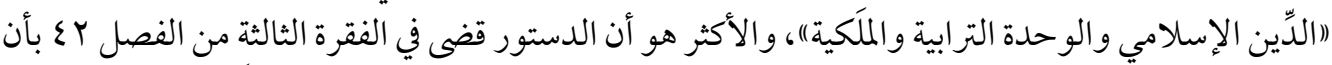

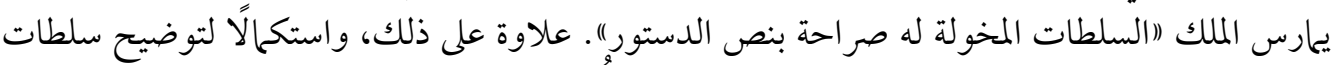

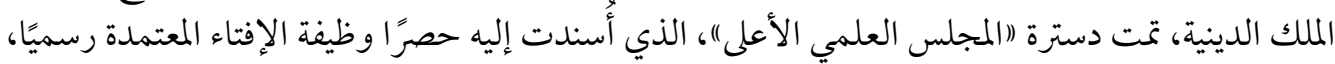

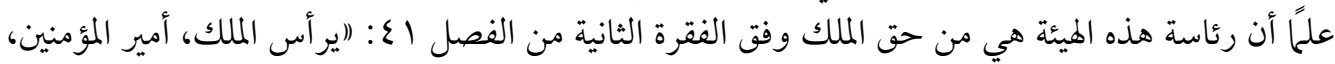

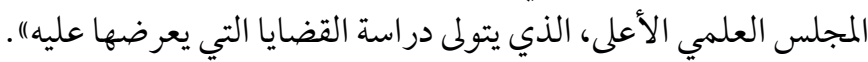

إلى جانب (إمارة المؤمنين)، وما ترتّب عن توظيفها من إشكاليات دستورية وسياسية، وفي صدارتها تأويل

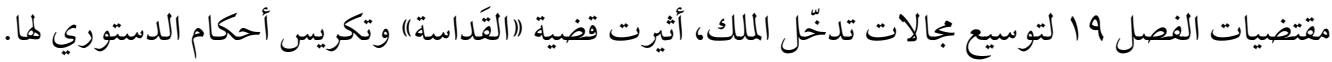

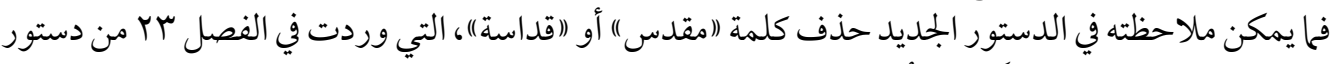

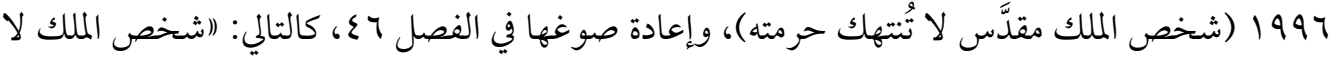

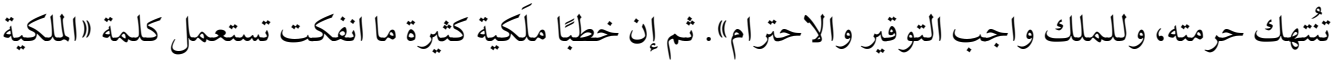

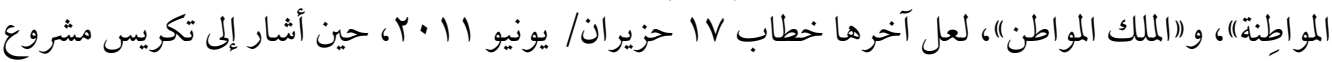

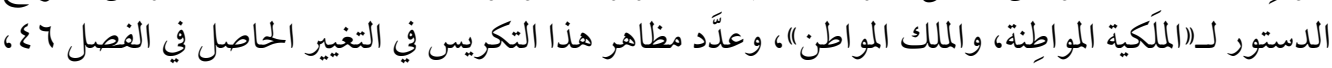

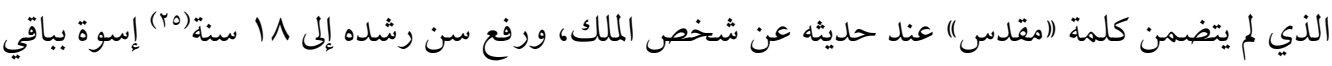

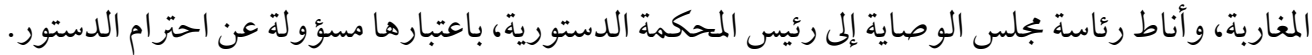

23 Rkia El Mossadeq, Acteurs politiques dans l'espace constitutionnel (Casablanca: Imprimerie Najah Al Jadida, 2011), p. 143.

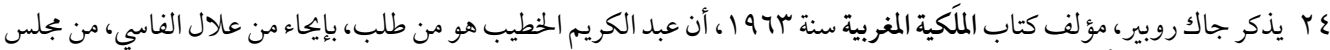

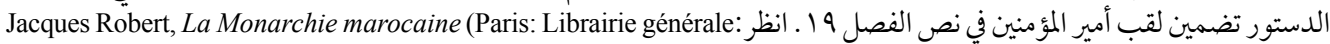
de droit et de jurisprudence, 1963).

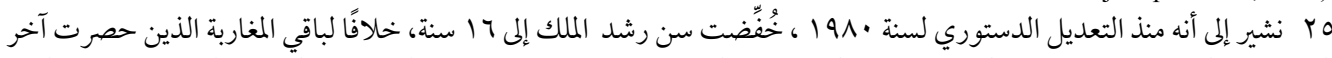

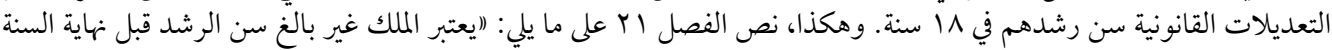


تضمّنت الهندسة الدستورية الجديدة، إلى جانب الأحكام الخاصة بمكانة الملك الدينية، جملة من الصلاحيات،

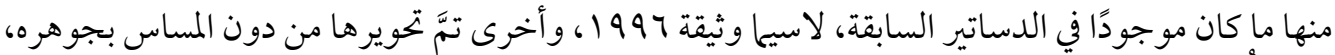

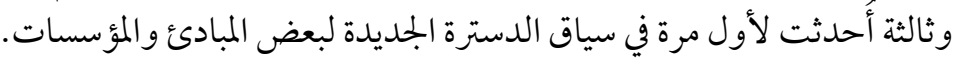

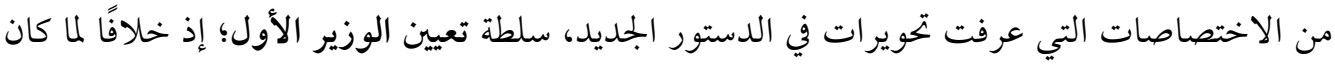

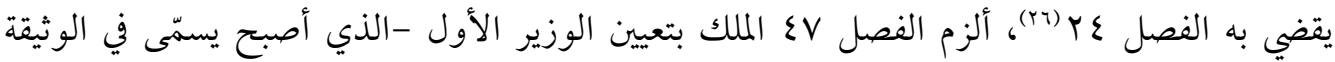

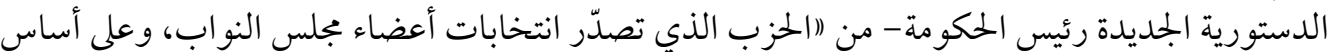

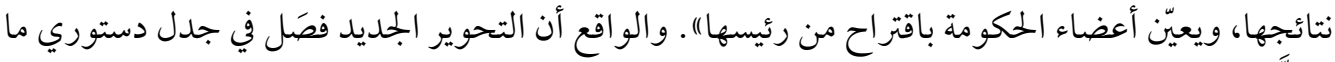

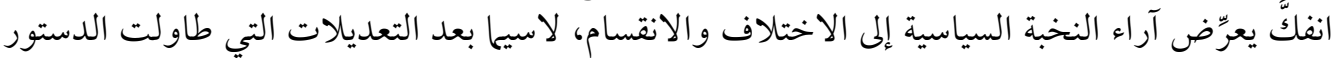

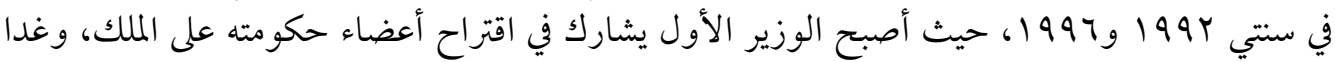

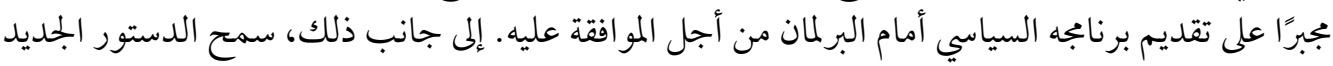

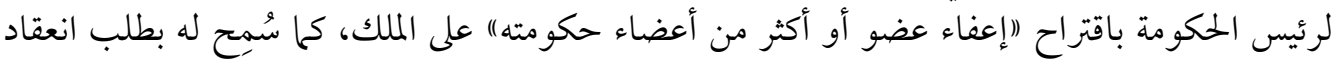

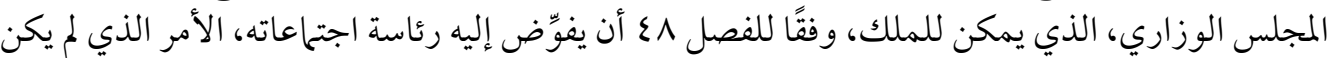

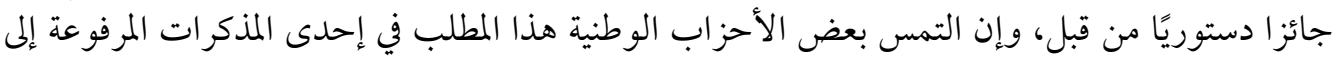

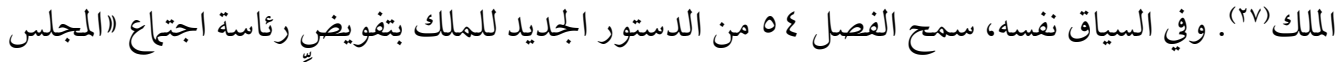

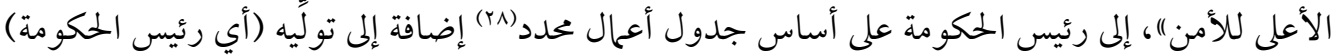

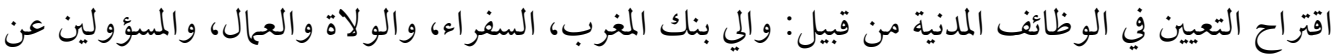

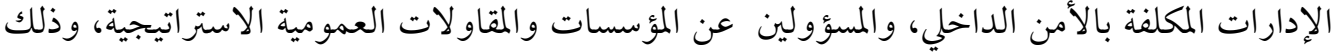
بمبادرة من الوزراء المعنيين.

علاوة على الاختصاصات التي أصبحت مُفوضة من الملك لرئيس الحكومة، استمر الملك، وفقًا للمهندسة الدستورية الجلديدة، في ممارسة بجموعة من الصلاحيات الحاتيات الخاصة به كرئيس للدولة، ومنها: رئاسته

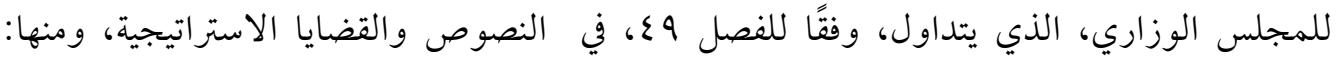

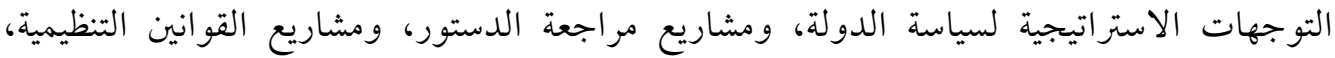

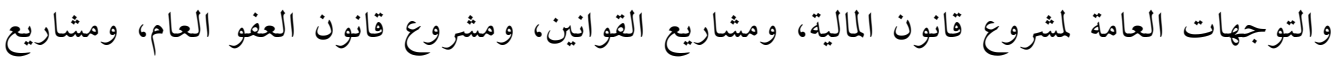

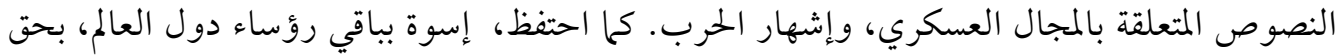

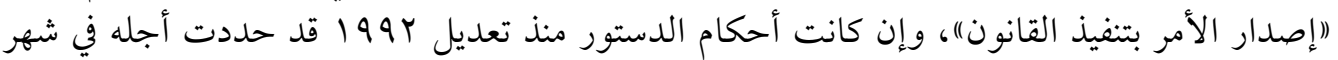

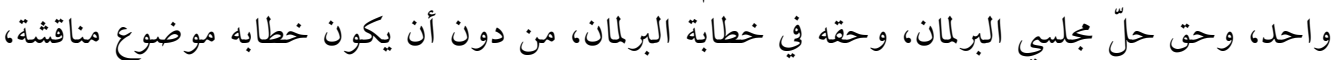

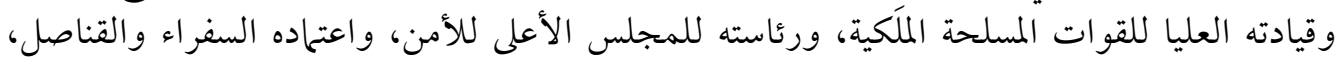

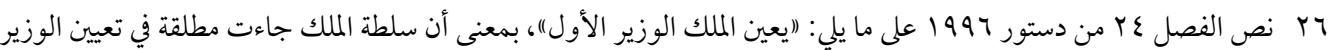

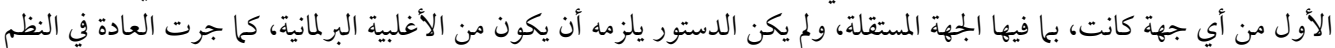

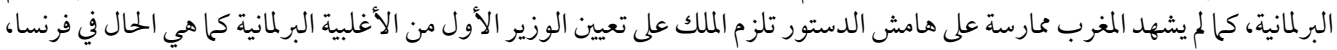

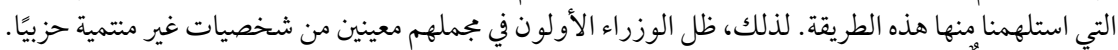

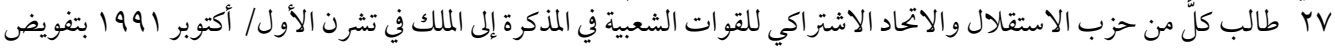

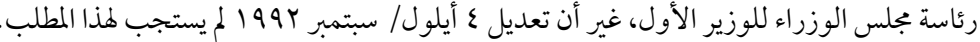

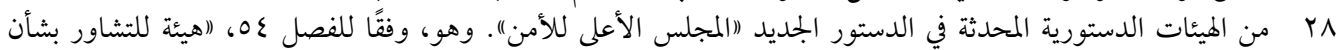

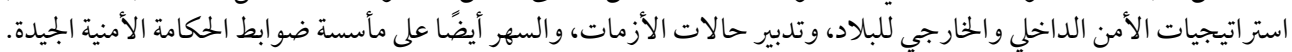


ورئاسته المجلس الأعلى للسلطة القضائية، وممارسة حق العفو، ناهيك عن حقه في إعلان حالة الاستثناء،

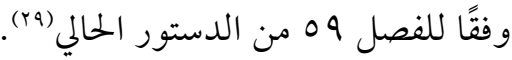

\section{عن موقع البرلمان والحكومة}

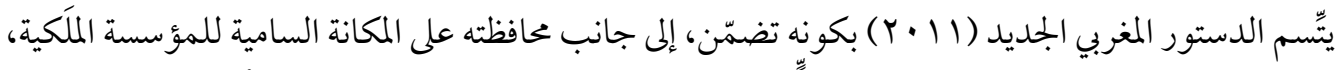

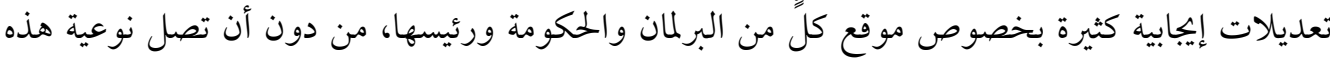

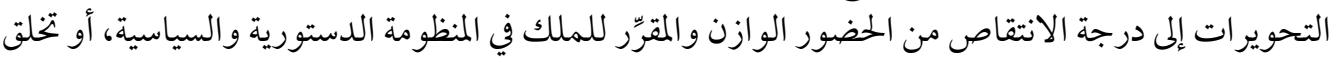

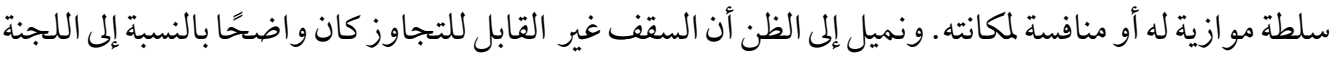

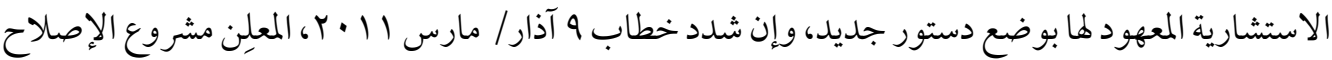

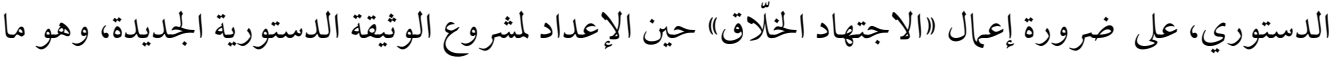

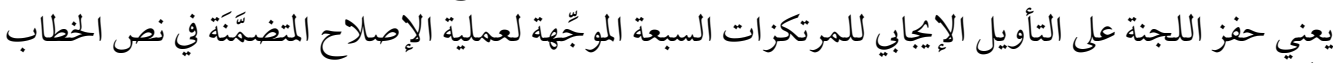

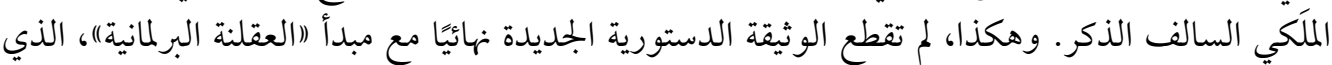

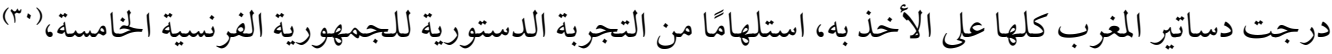

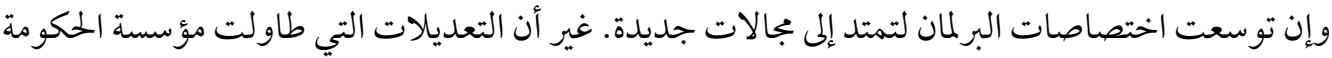

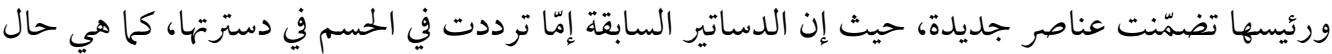

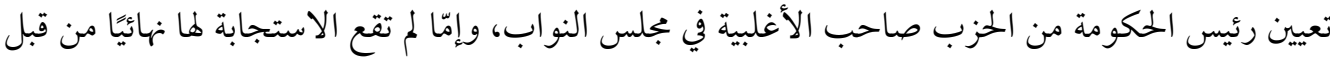
الإصلاحات الدستورية السابقة.

\section{برلمان متأرجح بين العقلنة والتطوير}

تأرجحت الوثيقة الدستورية المغربية الجديدة بين الاستجابة نسبيًا للدعوات المطالبة بإقرار (الملكية

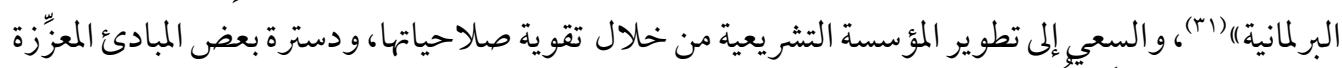

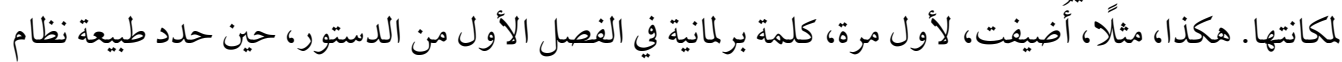

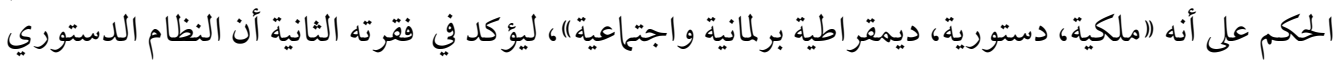

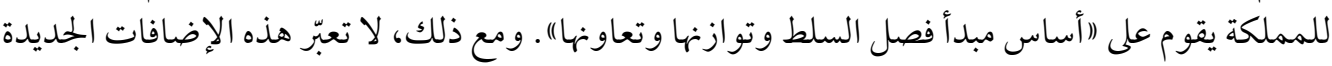

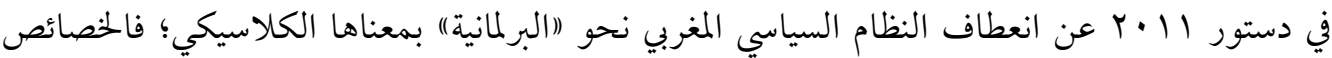

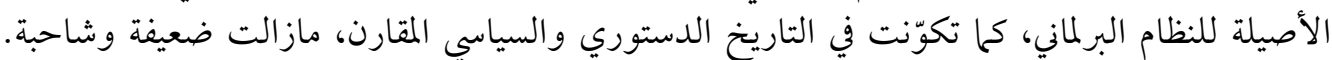

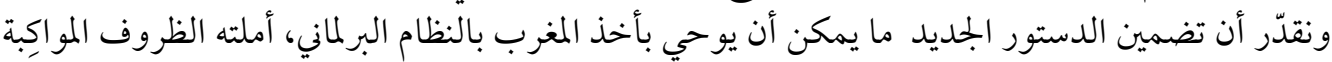

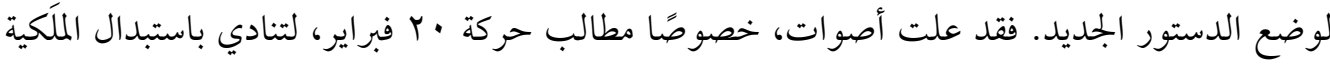
هو تجدر الإشارة إلى أن المغرب عاش حالة الاستثناء مرة واحدة بين سنتي 1970 و • 19V 1 ، حين لجأ الملك الحسن الثاني إلى إعمال

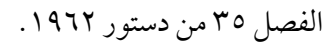

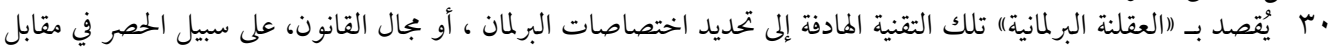

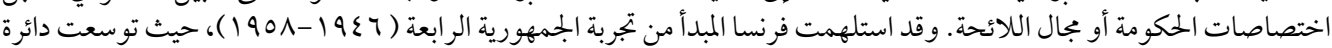

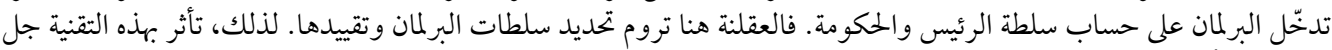

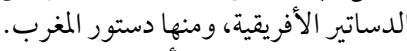

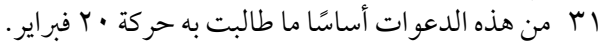


التنفيذية، السائدة لعقود، بملَكية بر لمانية، يكون الحكى فيها للمؤسسات المتتخبة. أمّا الملكية، فيقتصر دورها

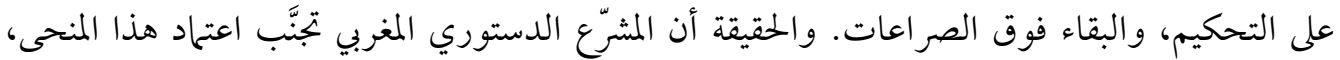

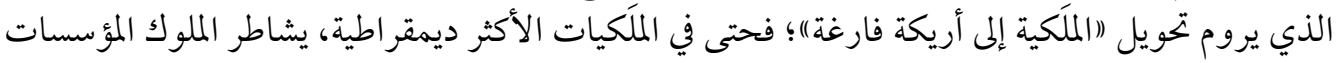

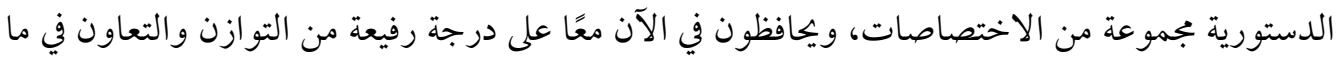

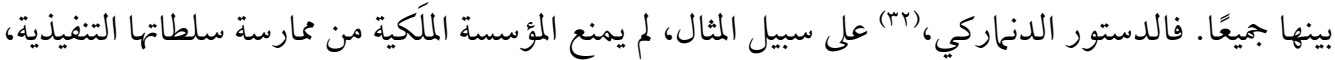

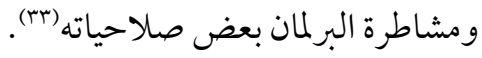

تسمح القراءة الفاحصة لدستور 11 • ب، لاسيا الأحكام ذات الصلة بالبرلمان، وبالملكية إلى حد ما، في علاقتها بباقي المؤسسات، باستنتاج مفاده حرص المشرّع الدستوري على التوفيق بين تقوية الطابع البرلماني للنظام

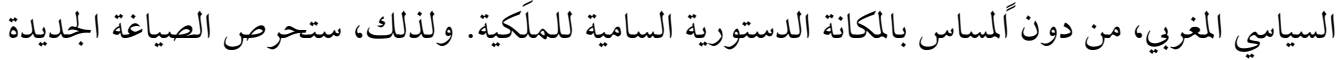

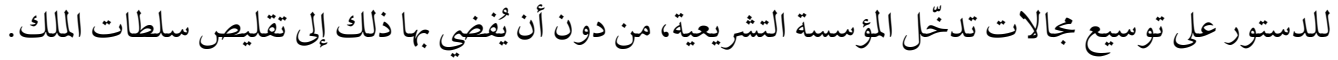

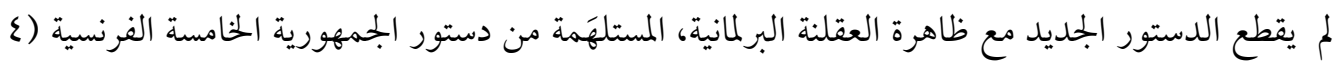

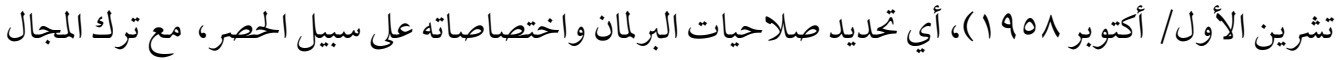

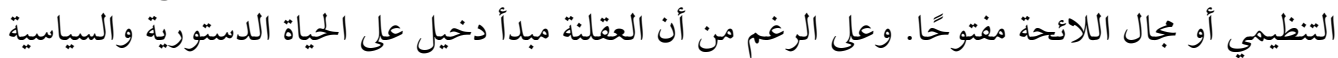

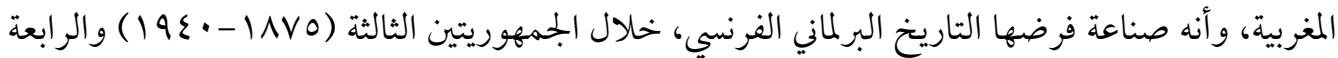

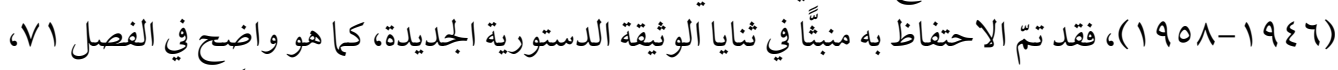

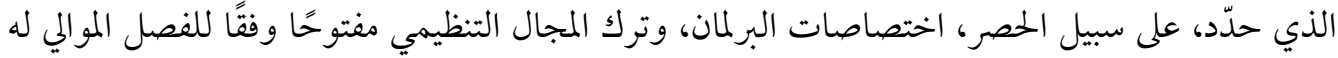

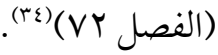

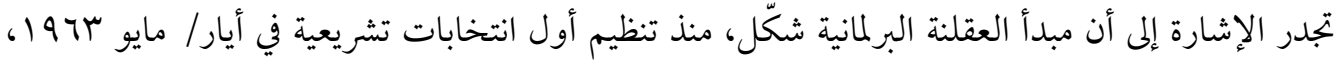

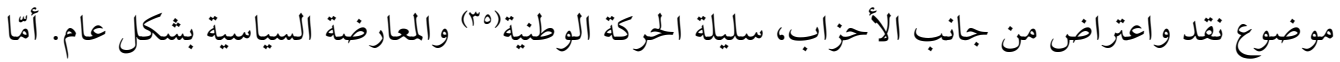

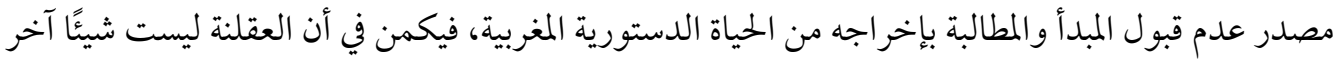

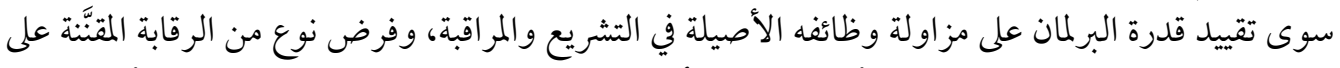

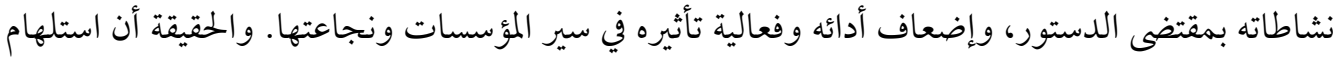

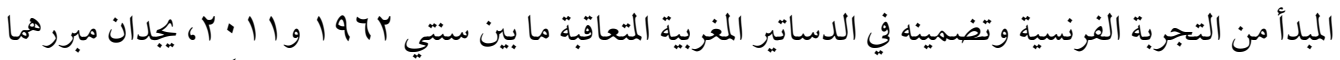

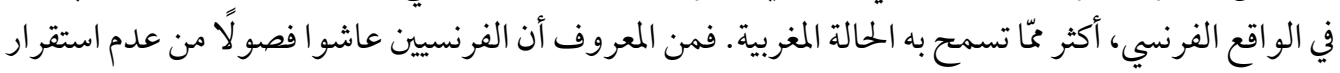

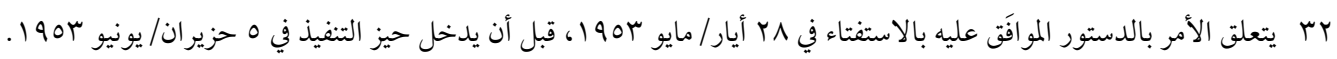
للاطلاع على نص الدستور، انظر: Recueil des constitutions européennes, publ. par Francis Delpérée, Marc Verdussen et

Karine Biver (Bruxelles: Bruylant, 1994), pp. 95-140.

33 Abderrahim El Maslouhi, «séparation des pouvoirs et regime Parlementaire dans la nouvelle constitution Marocaine,» dans : La Constitution marocaine de 2011: Lectures croisées: Actes des colloques, organisés par le Centre Maurice Hauriou de la Faculté de droit de l'Université Paris Descartes; l'Observatoire d'études géopolitiques et la Revue marocaine d'administration locale et de développement à l'École nationale d'administration à Rabat, le 22 juin 2011 et à l'École nationale d'administration à Paris, le 30 juin 2011; [sous la direction de Ahmed Bouachik, Michel Degoffe et Charles Saint-Prot], Thèmes actuels; 77 (Rabat: Publications de la «Revue marocaine d'administration locale et de développement», 2012), pp. 85 - 112.

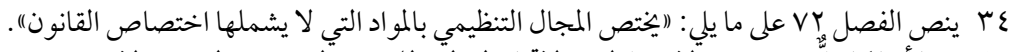

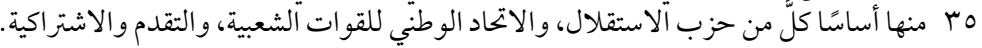




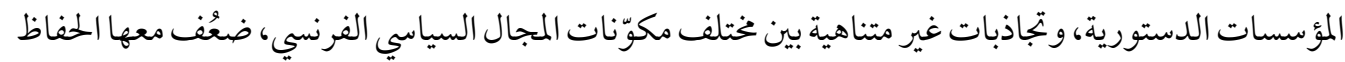

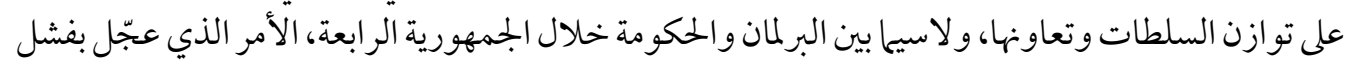

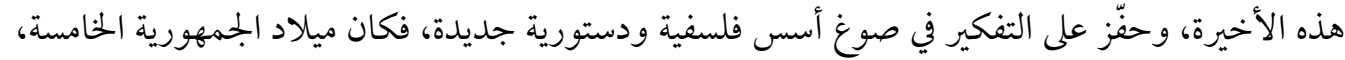

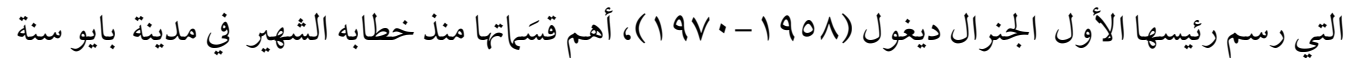

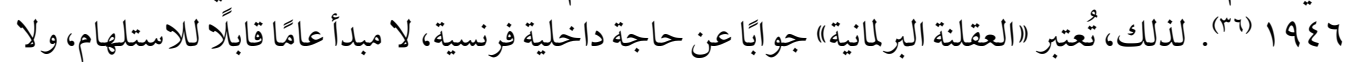

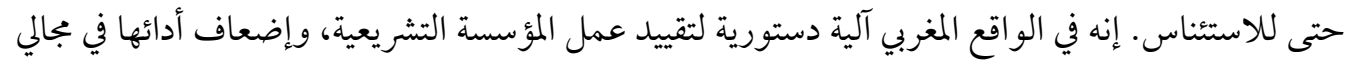

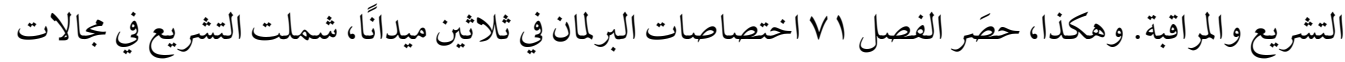

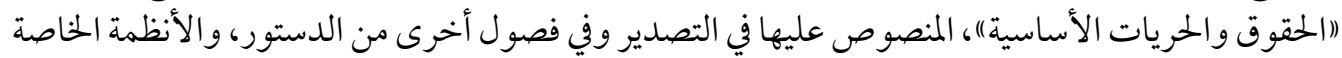

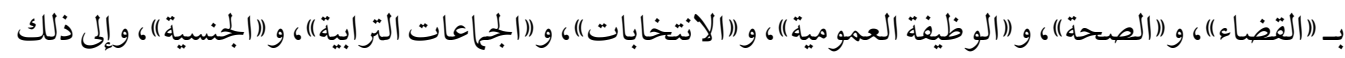

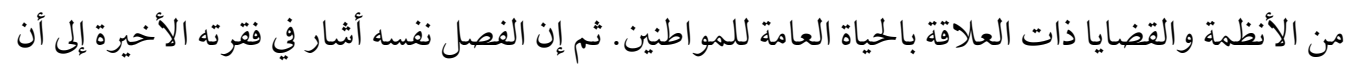

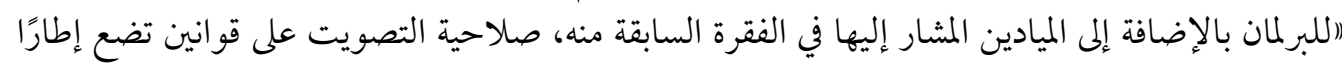

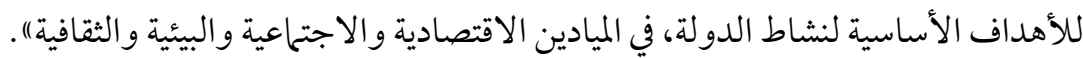

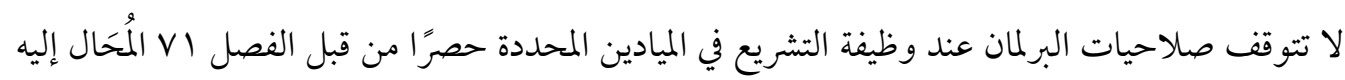

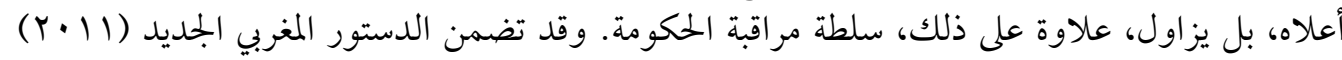

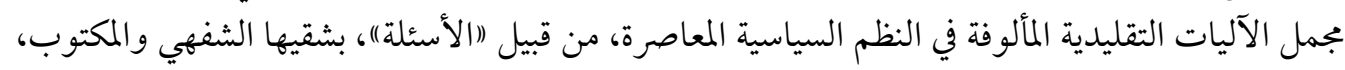

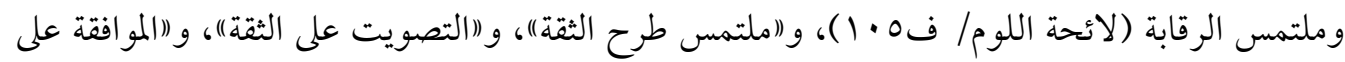

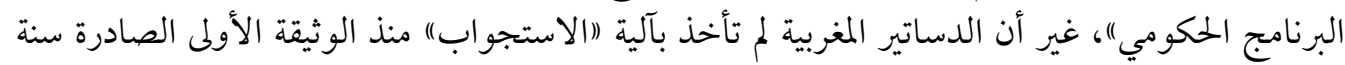

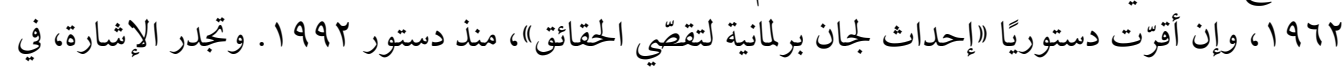

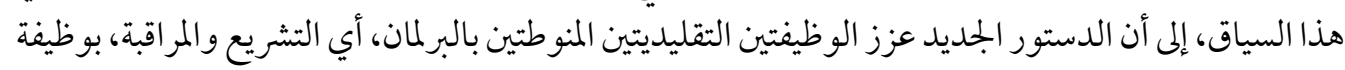

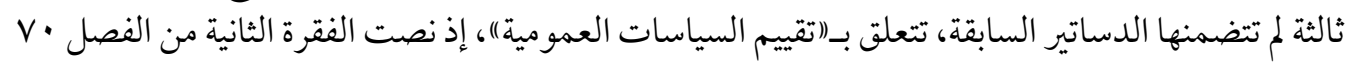

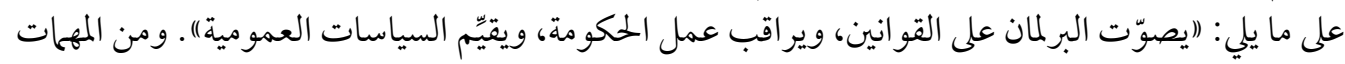

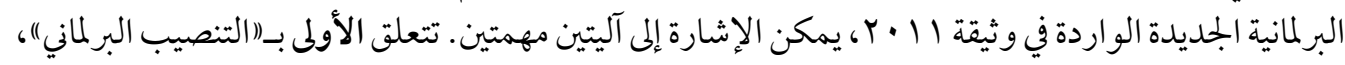

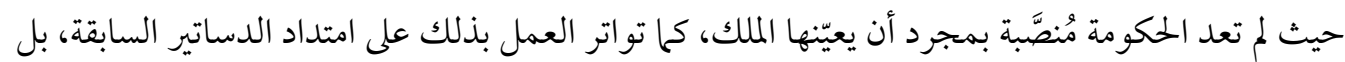

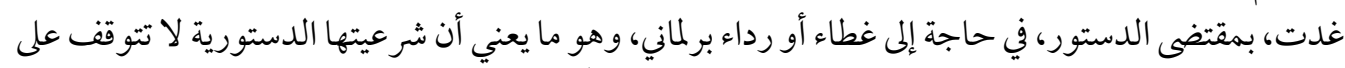

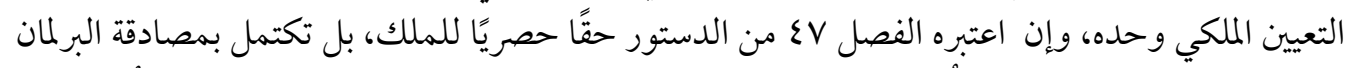

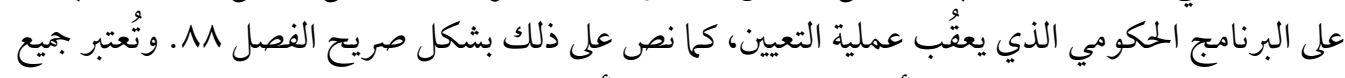

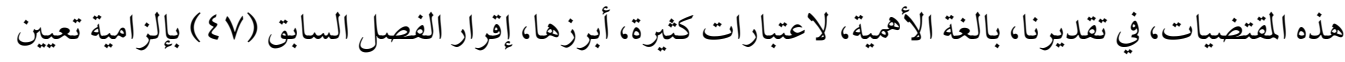

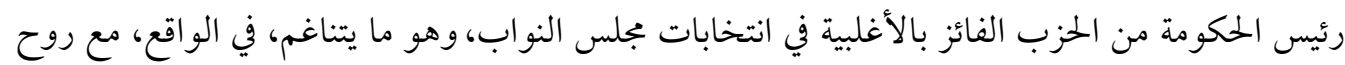

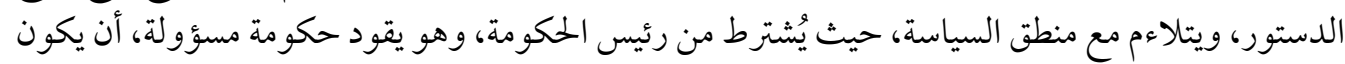

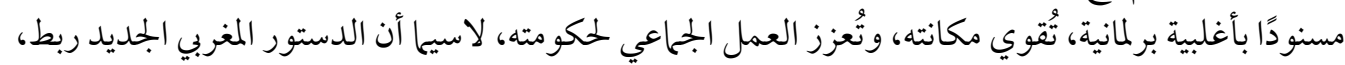

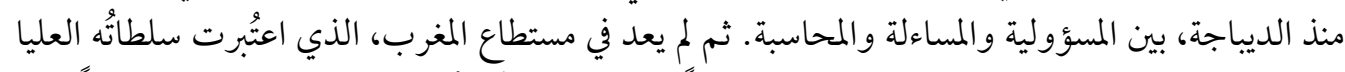

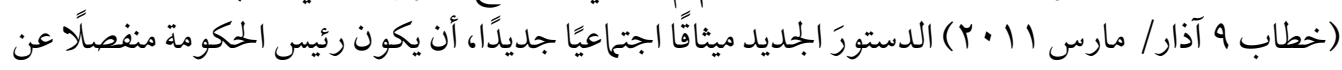

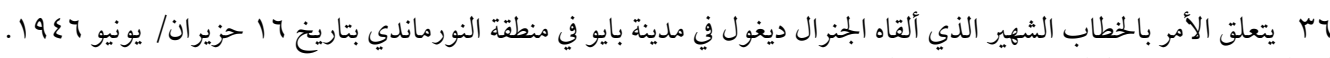
للاطلاع على سياق الخطاب ومضمونه، انظر:Jean-Louis Quermonne et Dominique Chagnollaud, Le Gouvernement de la

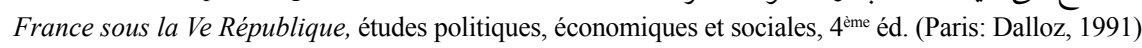


جسدها، أي غير منتسب إلى أغلبيتها، كما كان عليه الأمر في السابق. أما الآلية الثانية، فتتعلق بها ورد في الفصل

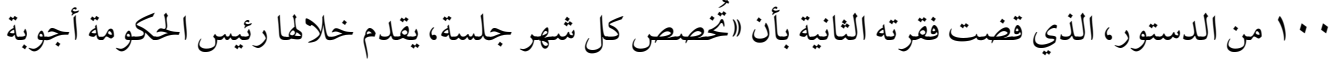

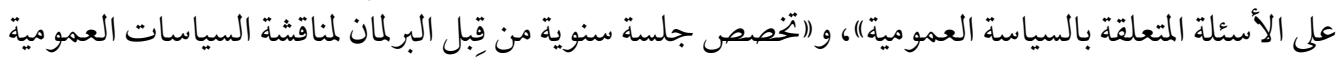

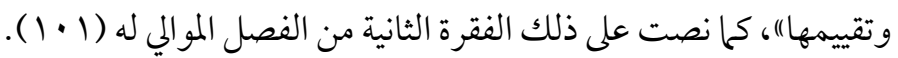

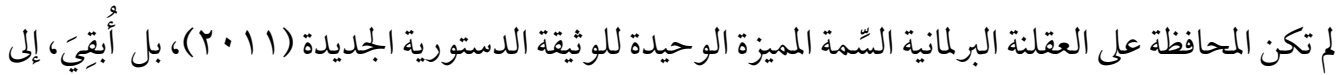

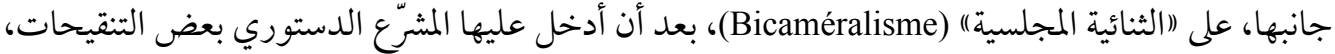

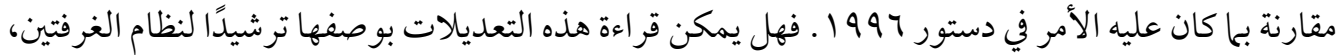

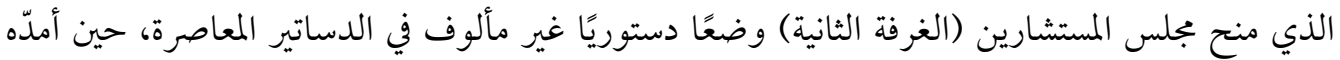

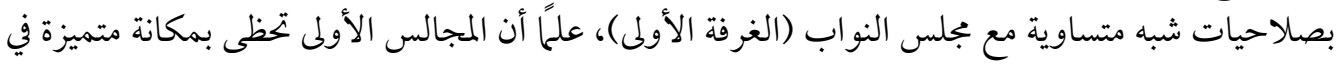

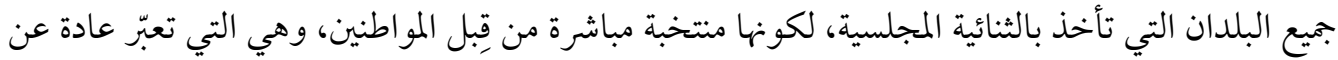

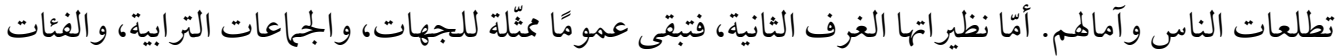

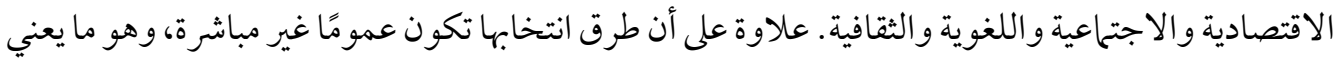

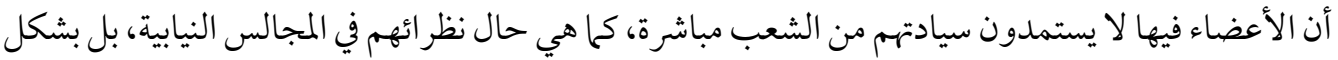

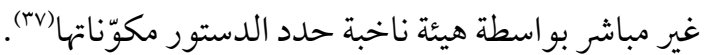

\section{حكومة بصلاحيات تنفيذية}

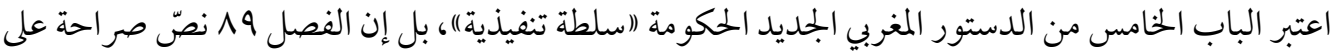

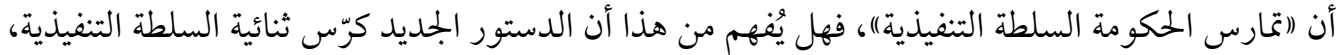

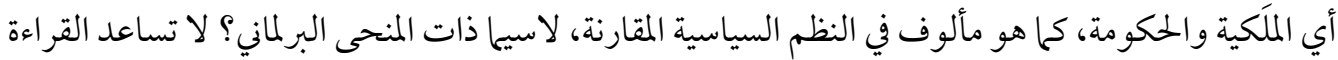

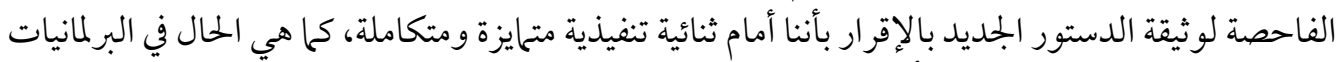

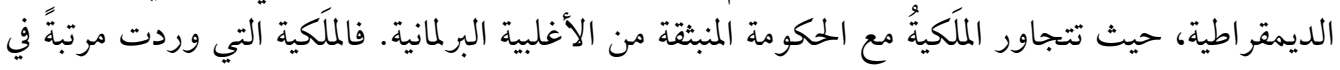

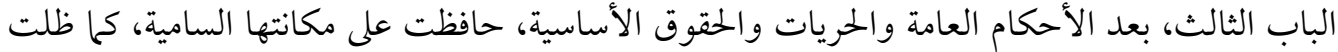
خارج التقسيم الأفقي للسلطات الدستورية الثلاث. ويؤكد هذا الاستتاج استمرار التأويل السائد لمبدأ

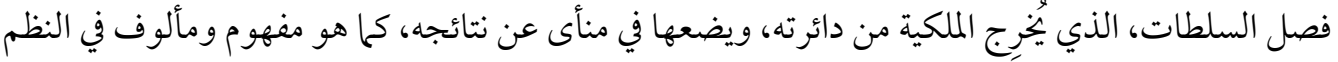

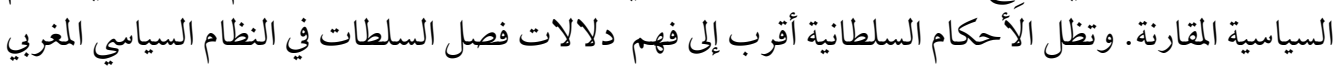

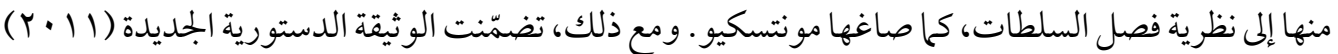

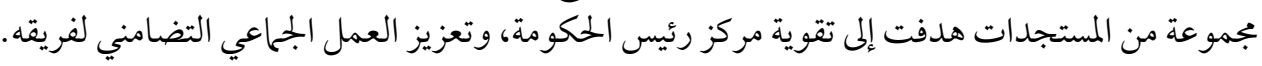

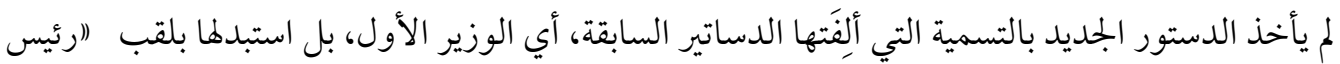

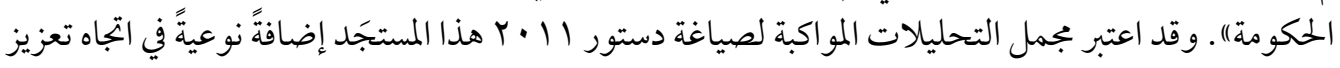

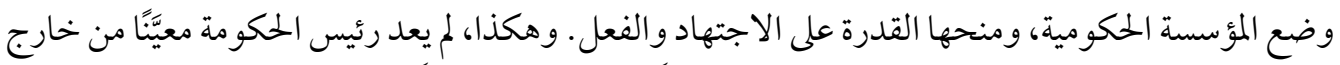

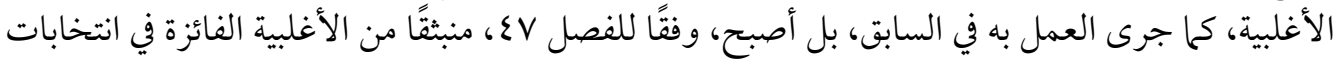

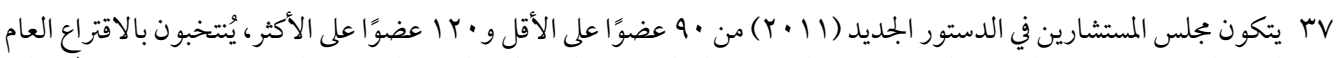

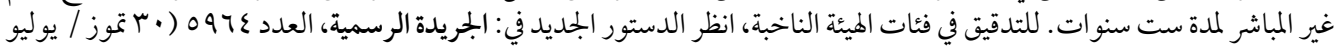




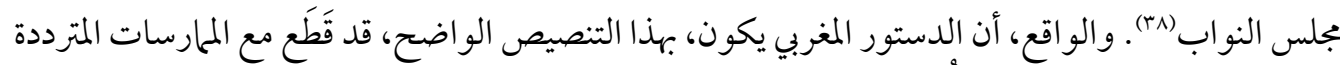

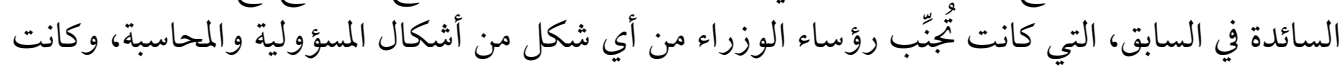

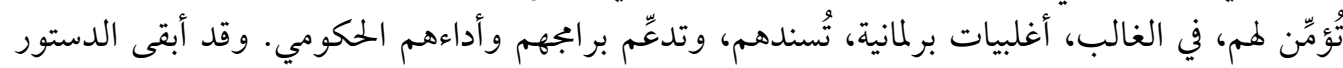

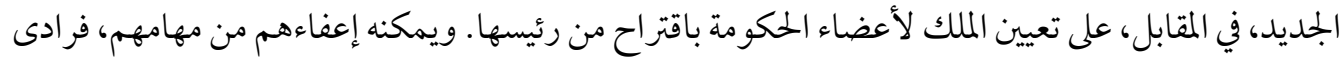

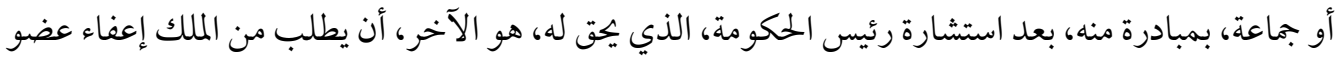

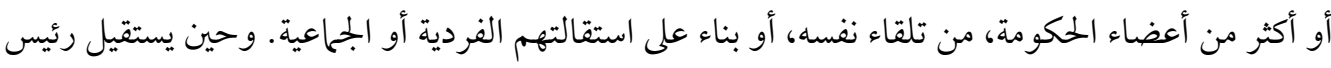

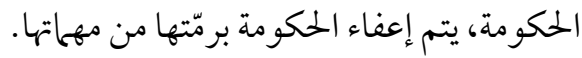

يمكن أن نُضيف، إلى جانب مستجد استبدال تسمية رئيس الوزراء باسم رئيس الحكومة، قاعدة قاعدة جديدة،

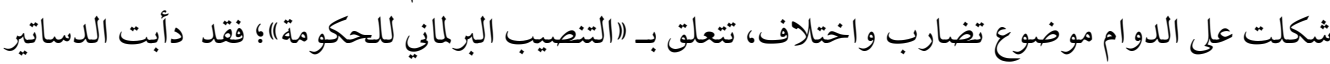

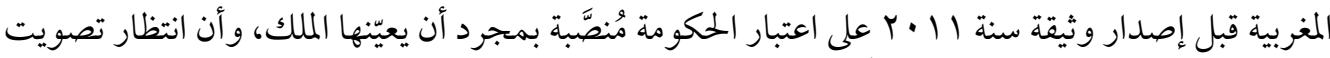

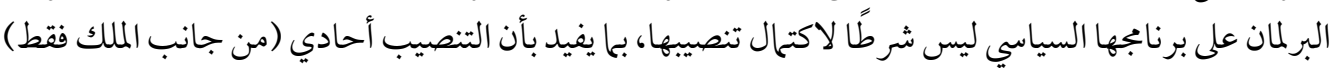

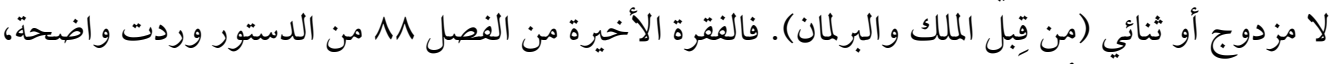

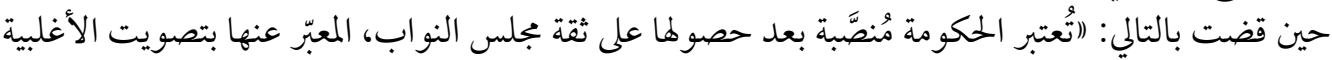

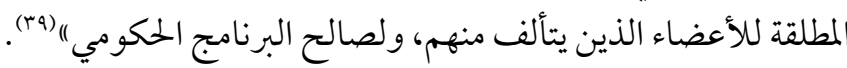

تجدر الإشارة إلى أن المقتضيات الواردة في الفصل الثامن والثمانين، لاسيها في فقرته الأخيرة، وإن حسمت بشكل

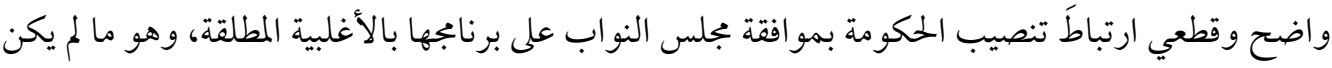

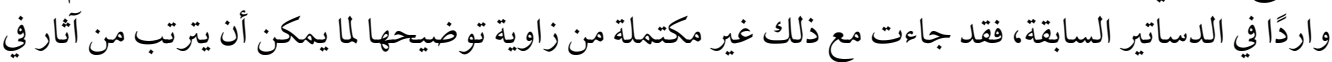

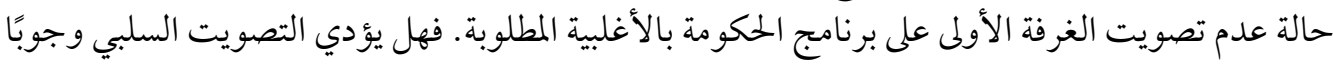

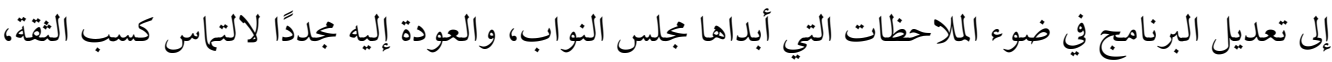

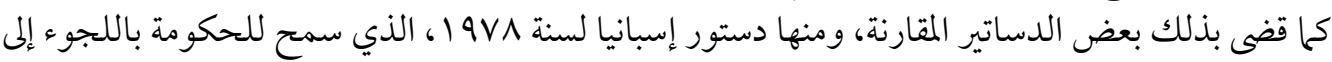

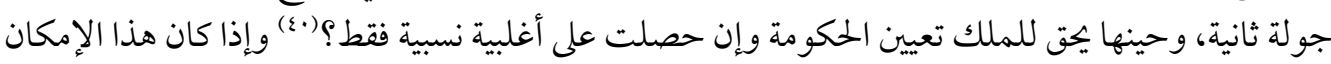

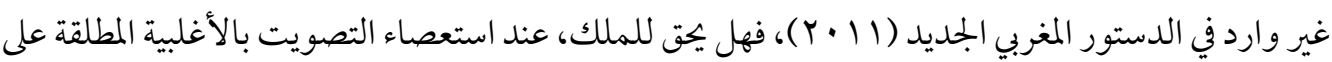

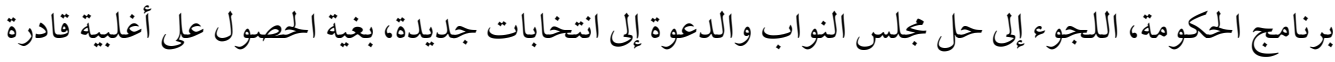

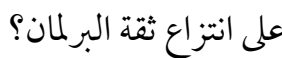

ستكون الإجابة بالنفي، ما دام الفصل ا 0، الذي سمح للملك بحل بجلسي البرلمان أو أحدهما، قد استلزم، إنهاء

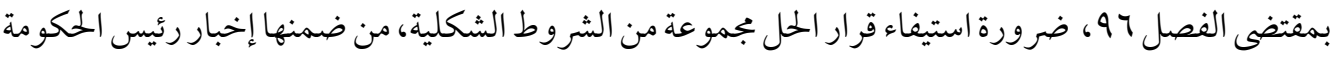

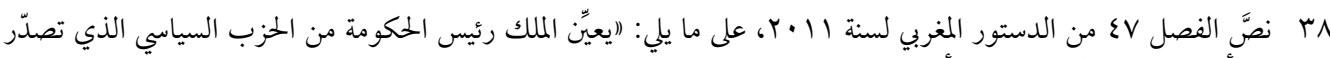

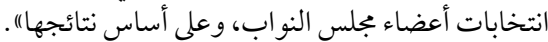

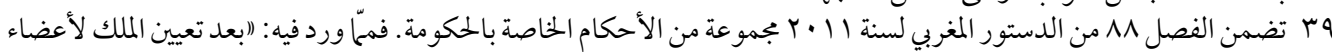

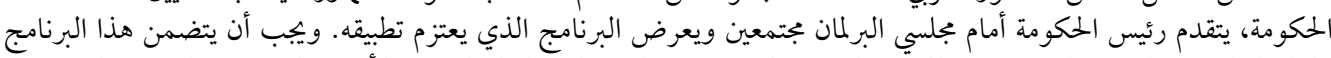

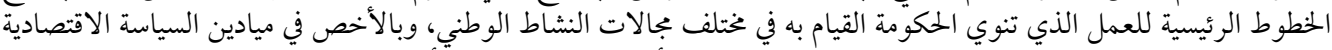

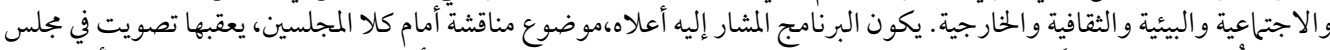

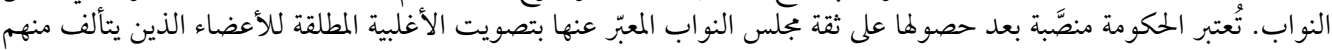

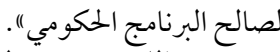

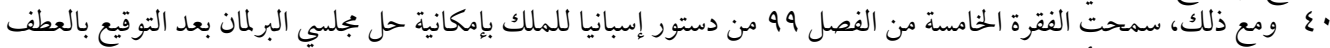

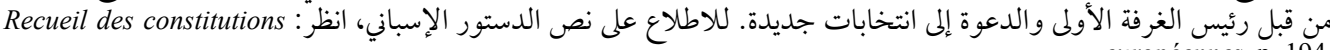




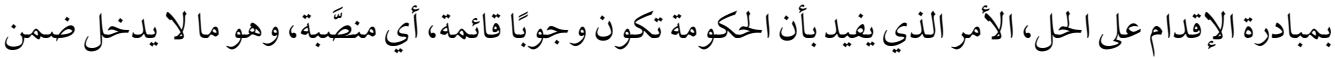

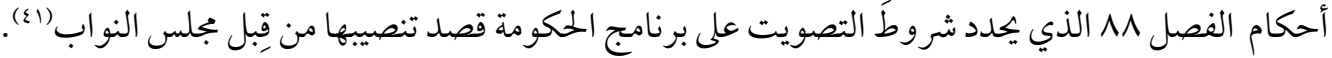
تجدر الإشارة، في هذا السياق، إلى أن دستور 997 إبط بين مو اصلة الحكو مة مهاتها وتصويت بجلس النواب

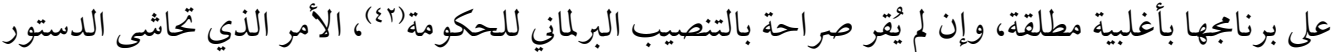

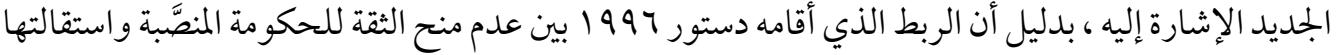

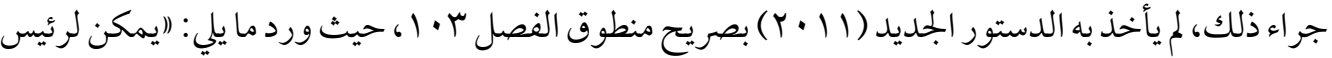

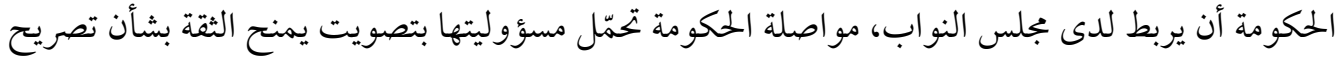

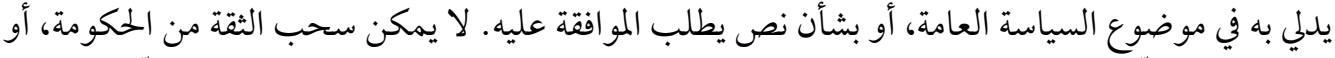

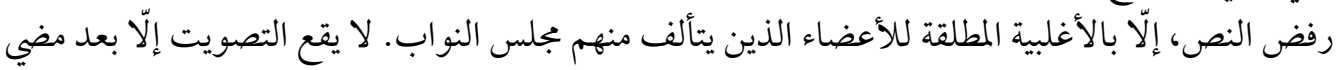
ثلاثة أيام كاملة على تاريخ طرح الثقة. يؤدي سحب الثقة إلى استقالة الحكومة استقالة جماعية)|(rاع).

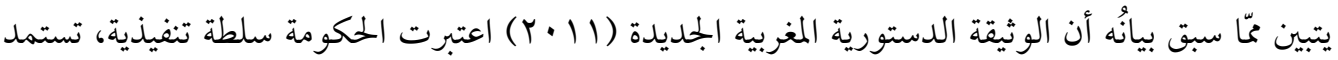

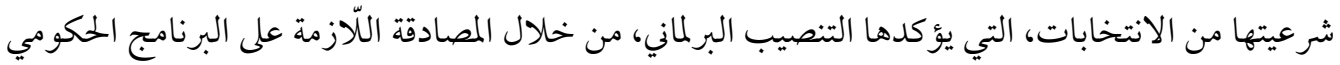

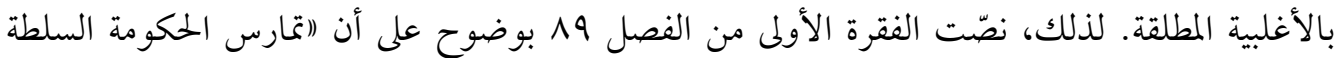

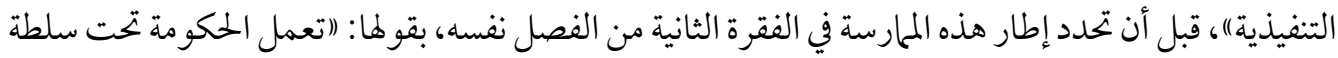

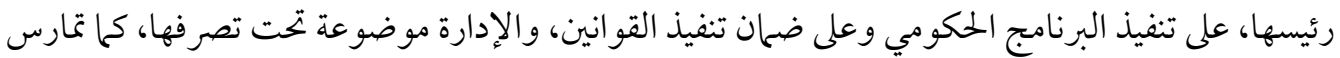

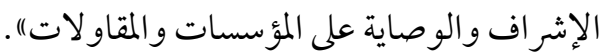

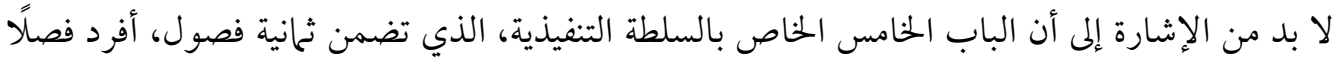

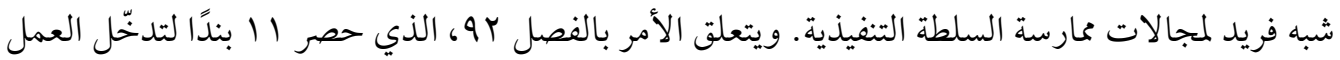

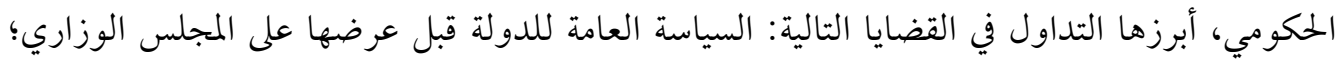

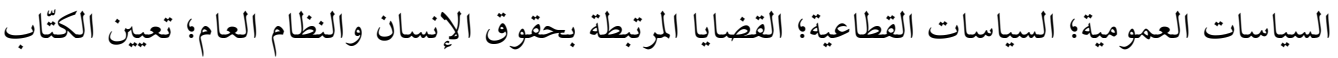

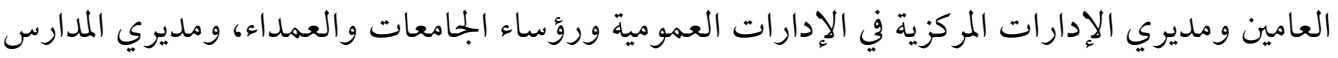

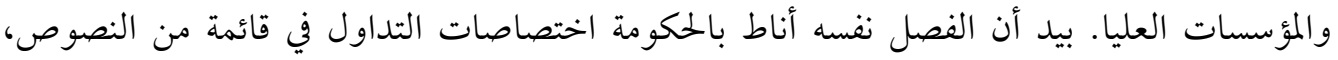

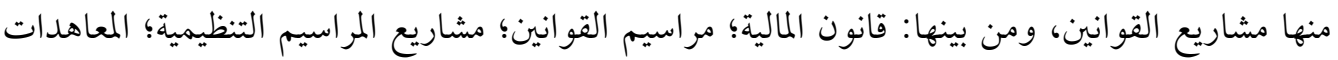

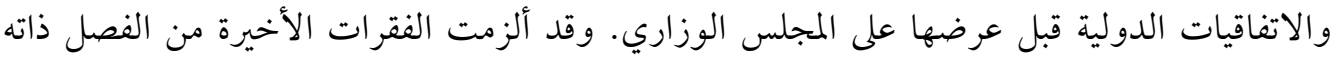

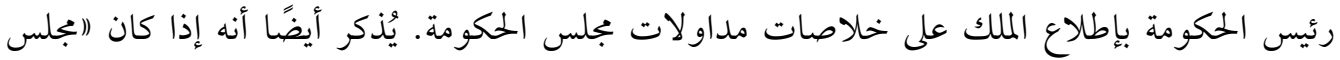

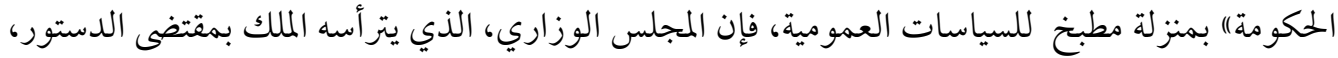

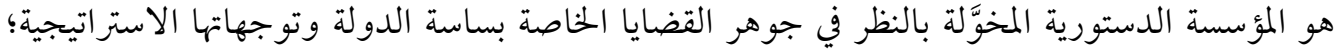

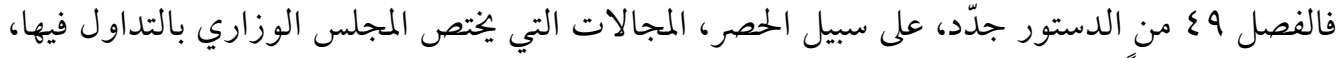

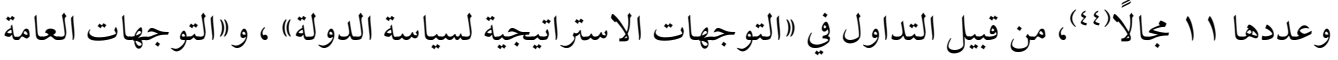

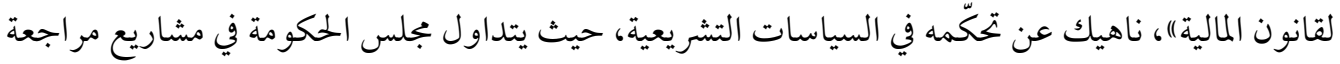

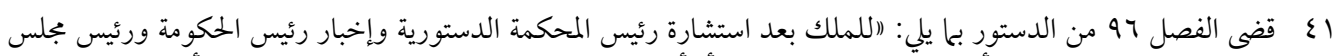

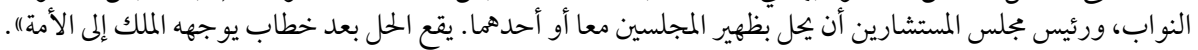

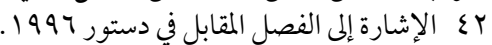

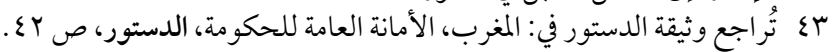

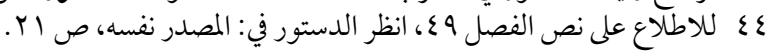




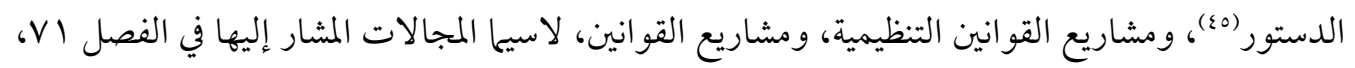

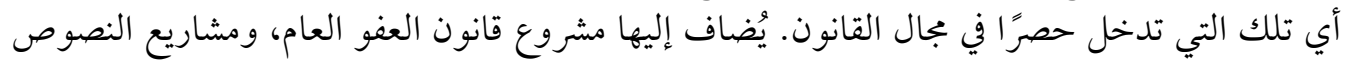

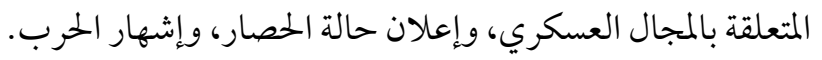

\section{دسترة استقلال القضاء}

أفردت الوثيقة الدستورية المغربية الجمديدة بابًِا مكوَّنًا من ا Y فصلًا (من الفصل V • ا إلى الفصل V V I ) للسلطة

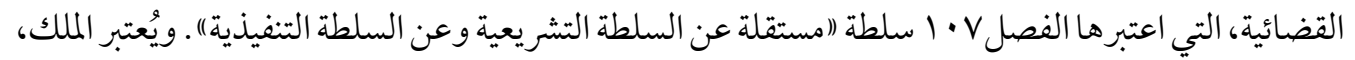

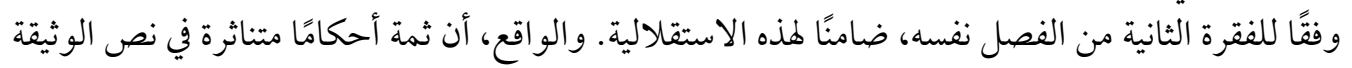

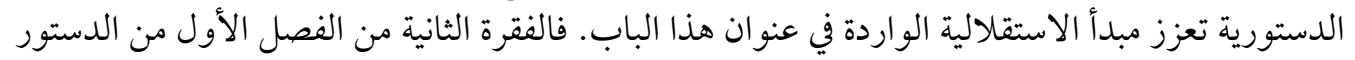

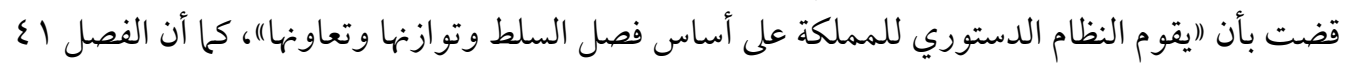

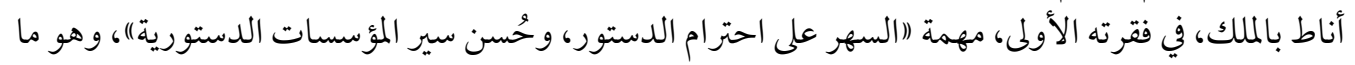

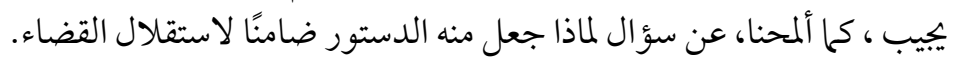

أولى الدستور الجديد أهمية واضحة لاستقلال القضاة من خلال أربعة فصول (من الفصل ^ • ا إلى الفصل

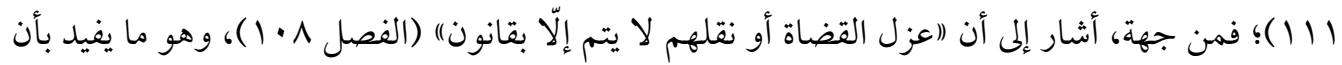

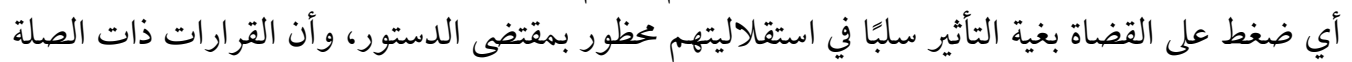

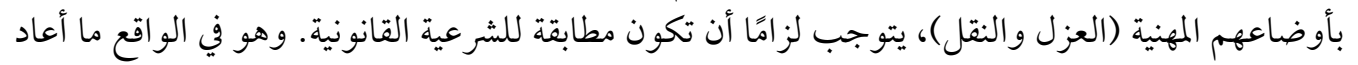

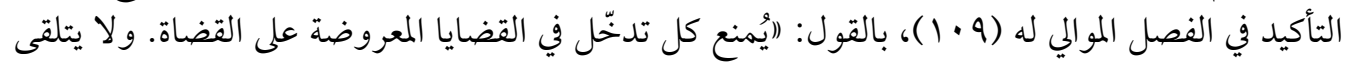

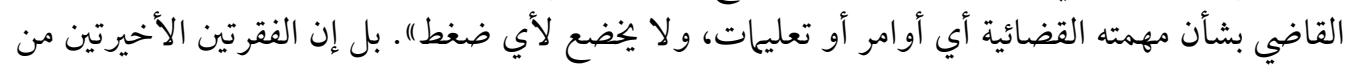

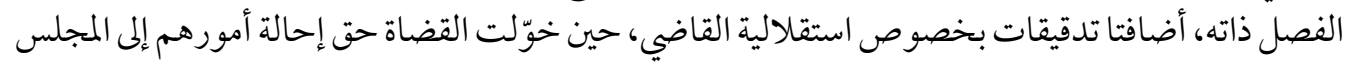

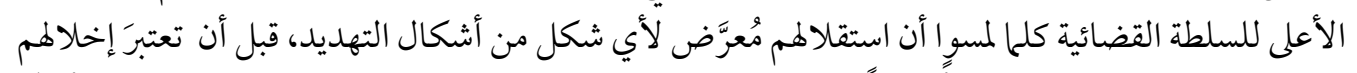

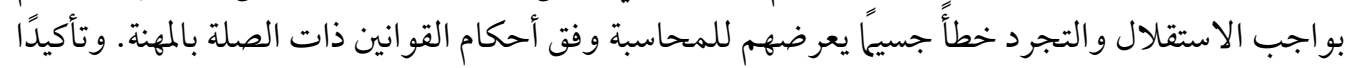

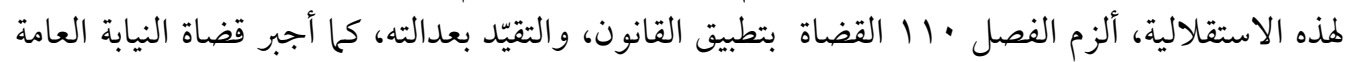

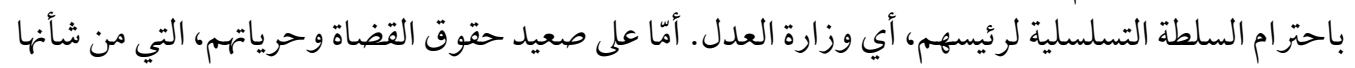
أن تعزز استقلالهم وتجرّدهم، فقد دققها الفصل ل1111، حين اعترف لهم بحرّية التعبير في الحدود التي تحترم

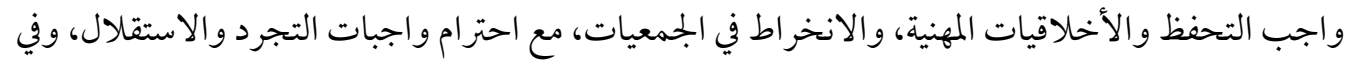
الآن معًا حظر عليهم الانتهاء إلى الأحزاب السياسية والمنظمات والات النقابية.

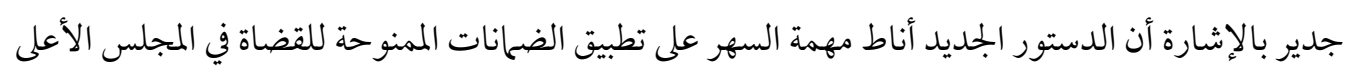

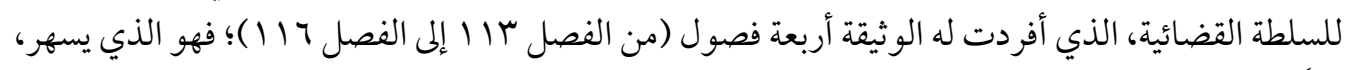

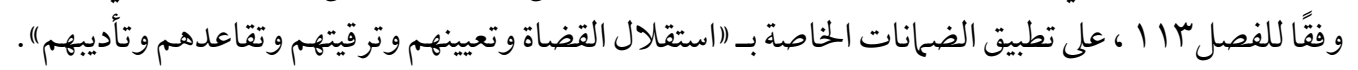

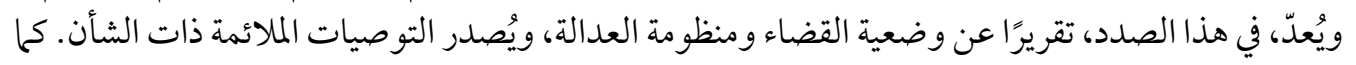

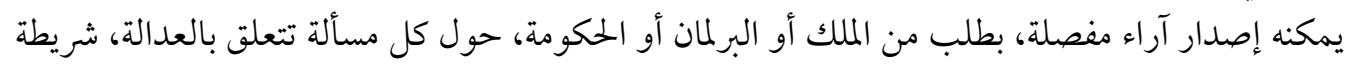
مراعاة مبدأ فصل السلطات.

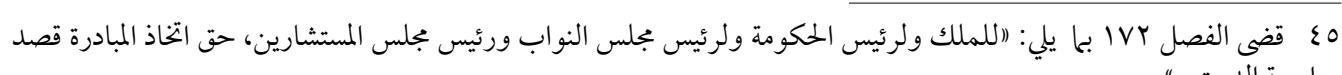




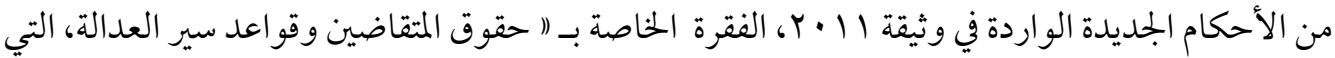

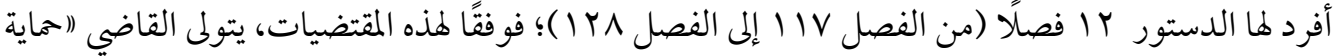

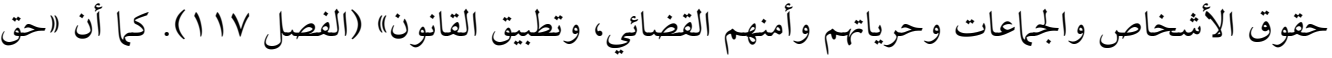

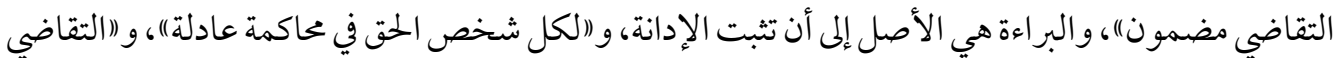

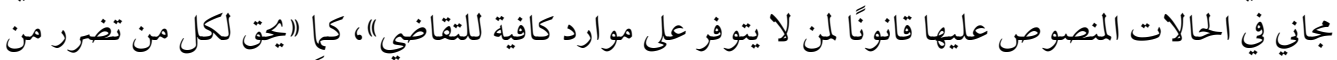

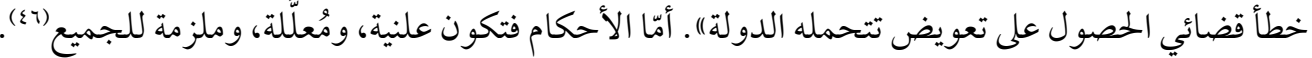

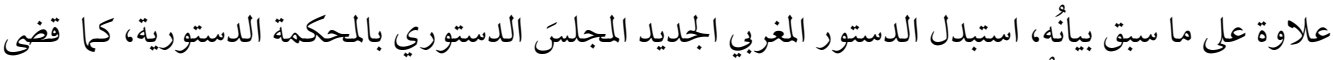

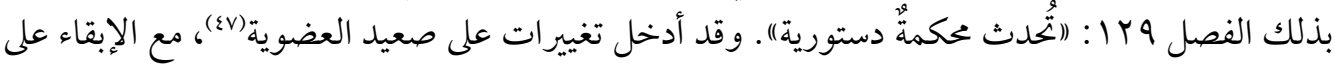

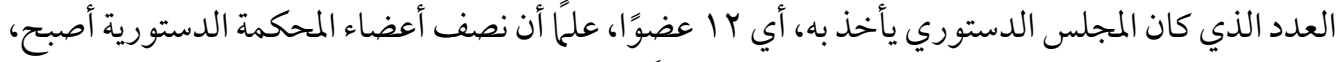

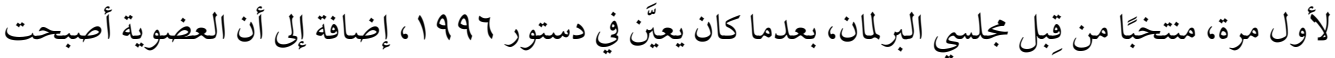

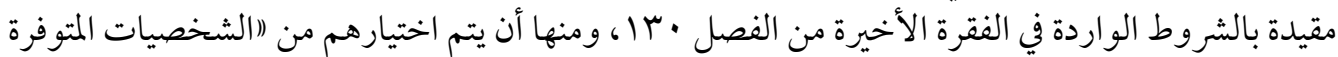

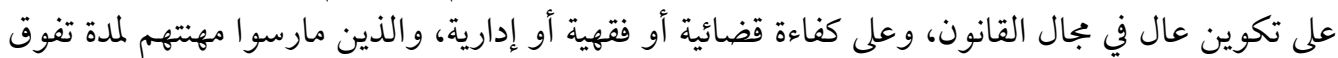

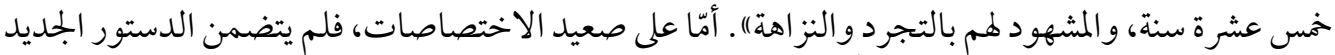

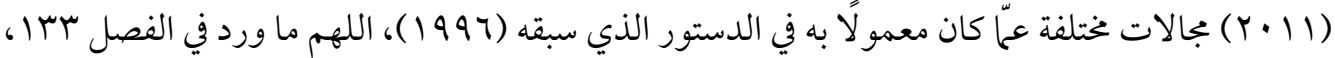

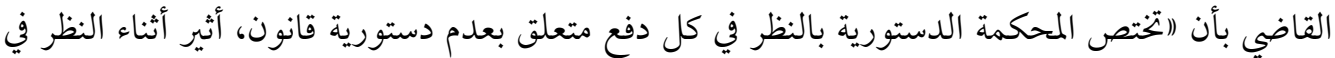

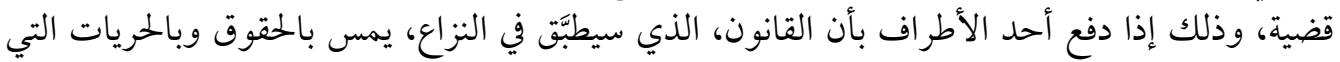

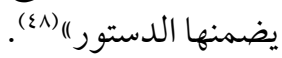

\section{مؤسسات حماية حقوق الإنسان والحكامة الجيدة}

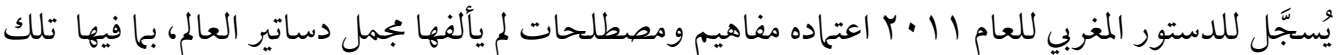

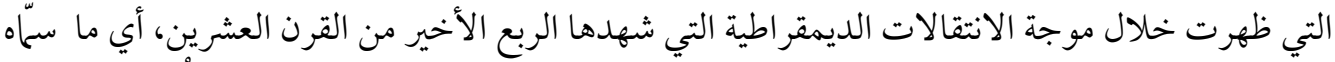

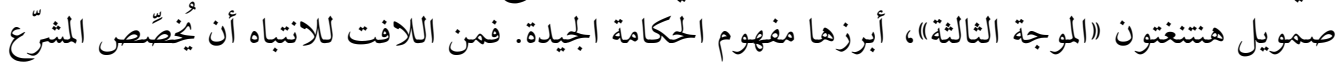

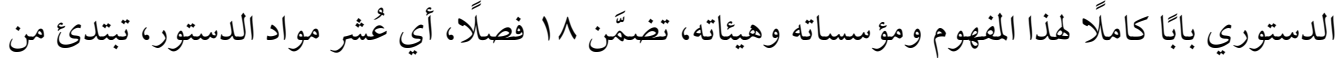

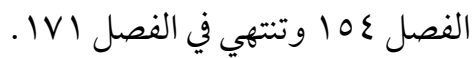

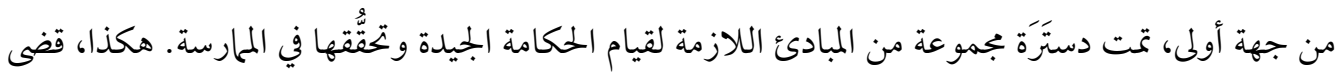

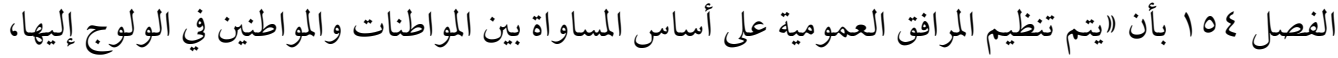

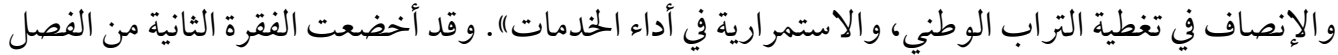

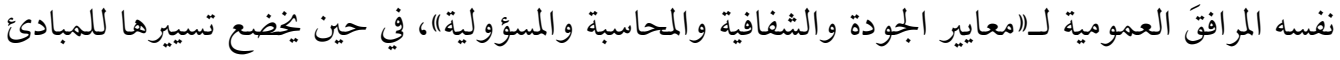

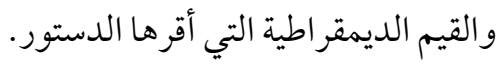

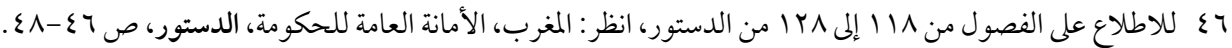

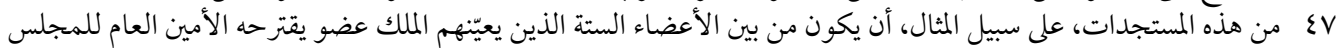

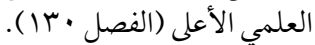

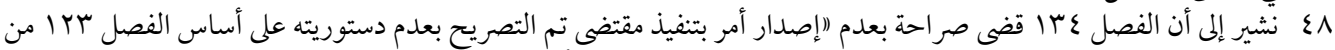

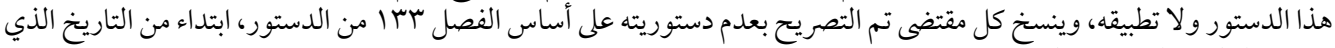




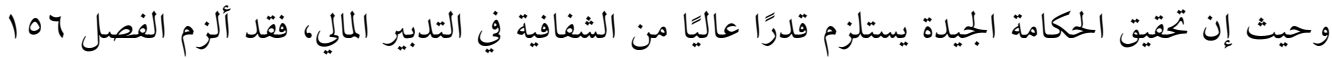

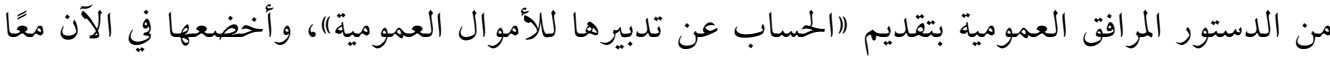

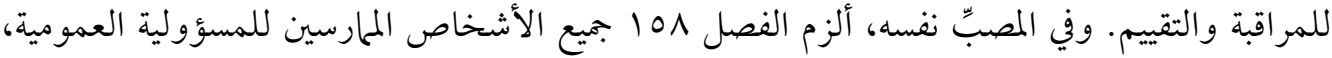

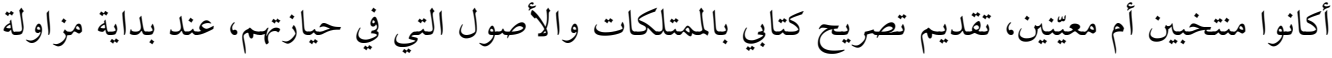
مهامه وفي نهايتها.

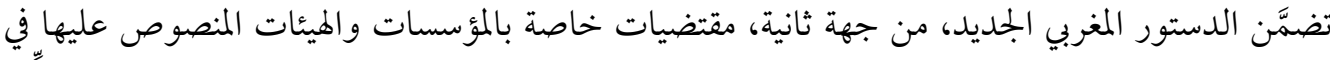

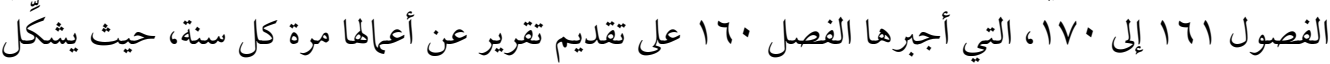

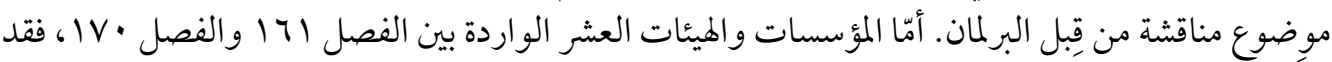

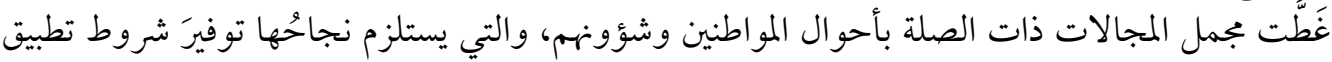

مبادئ الحكامة الجيدة.

يمكن التمييز، في نطاق المؤسسات والهيئات العشر التي تولّت الوثيقة الجديدة دَستَّتها، بين الهيئات الخاصة

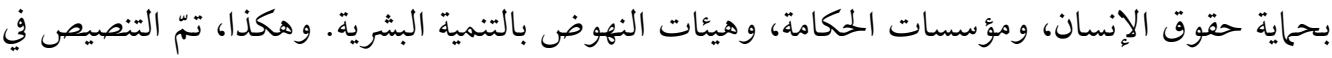

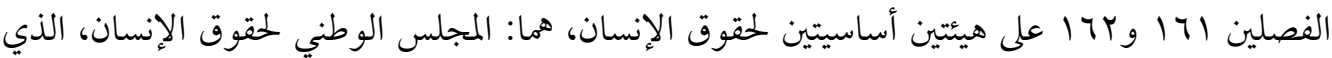

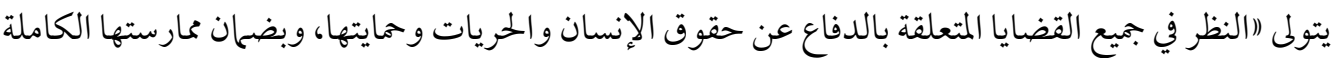

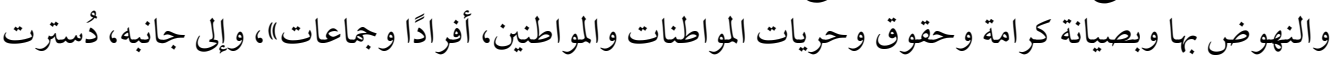

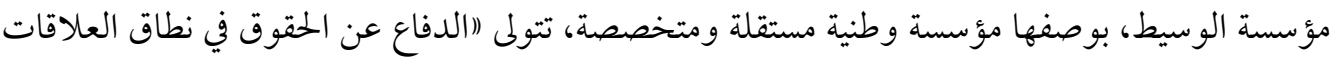

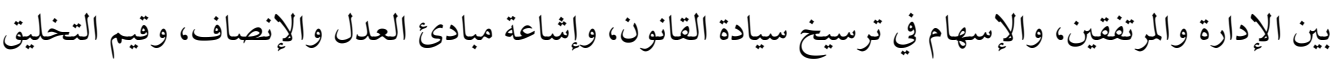

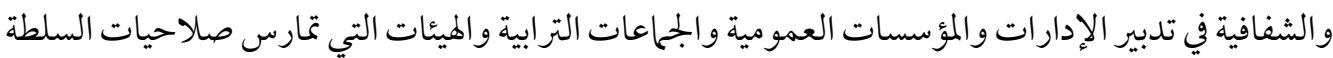

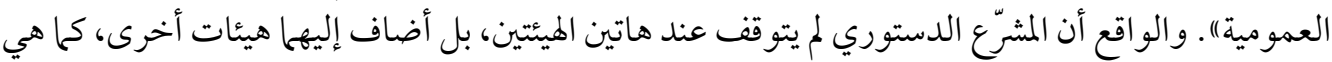

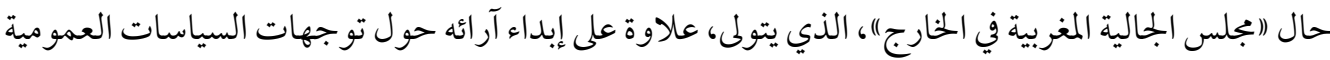

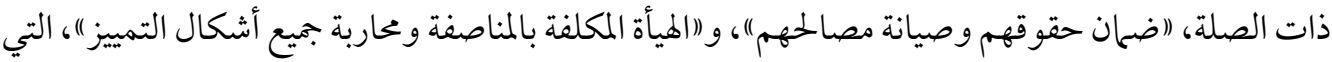

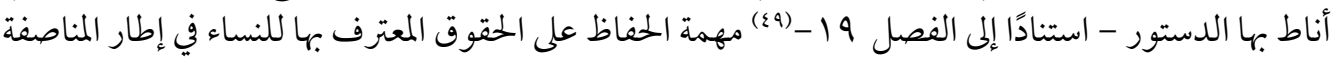

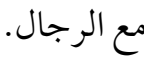

تضمَّن الدستور المغربي الجلديد ثلاث مؤسسات ذات علاقة بالحكامة الجيدة، هي على التوالي: (الهيئة العليا

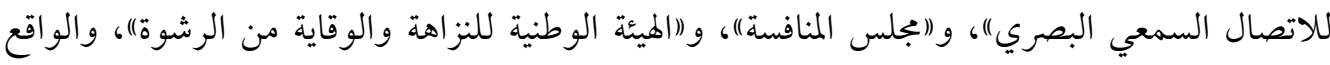
أن المؤسسات الثلاث، وإن كانت موجودة من قبل، أضفى عليها الدستور قيمة دستورية بالتنصيص علئه عليها

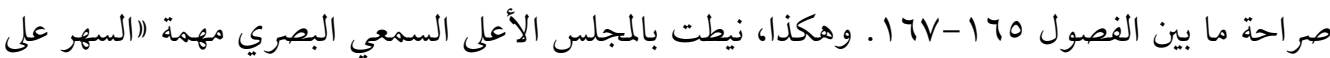

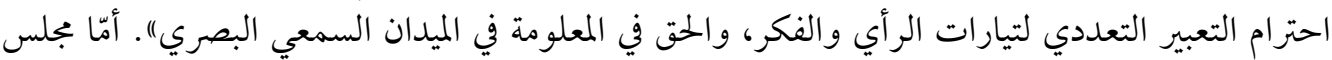

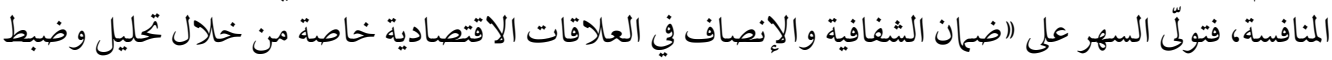

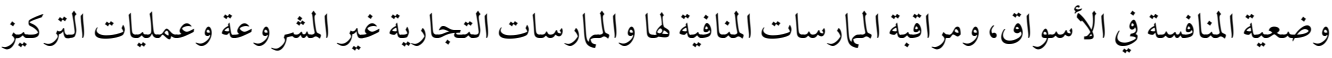

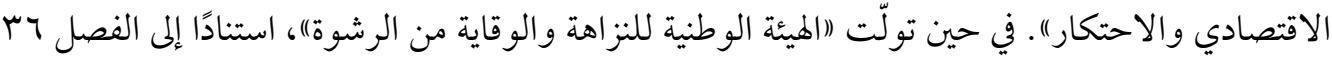




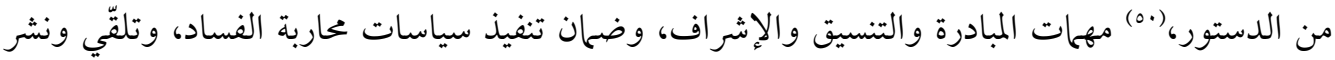

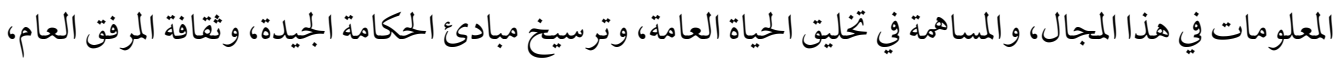

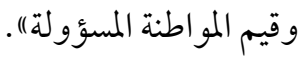

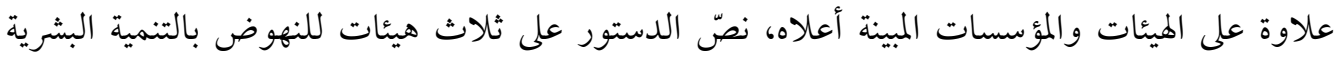

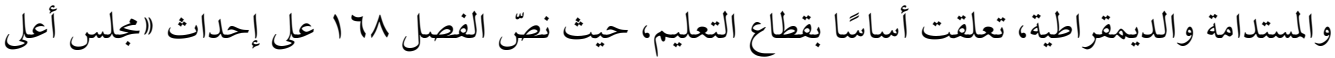

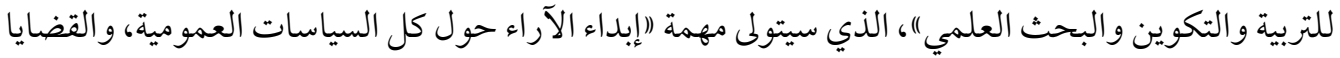

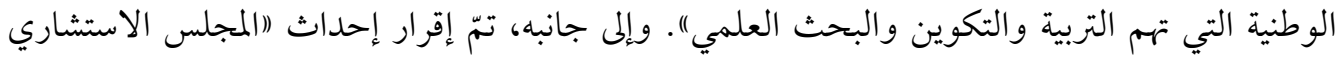

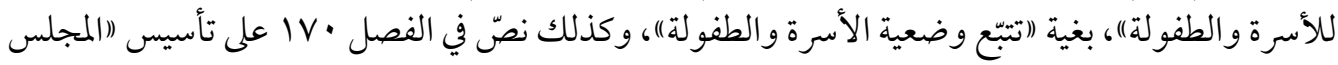

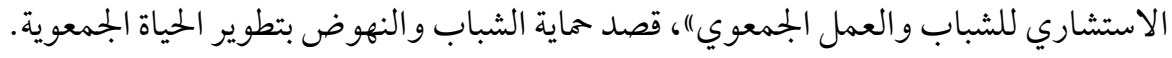

\section{خاتمة}

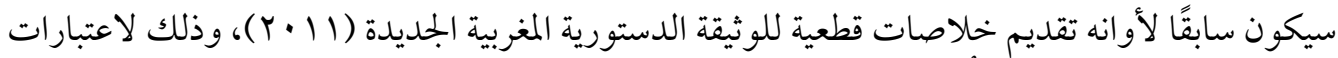

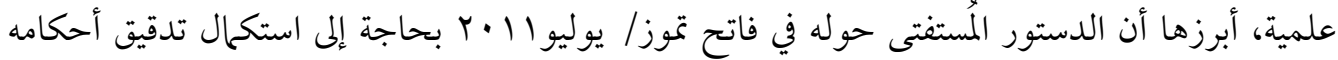

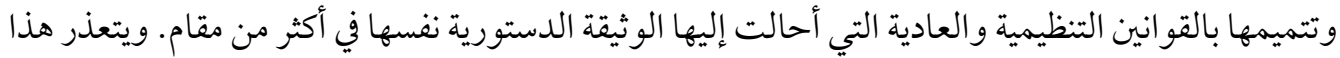

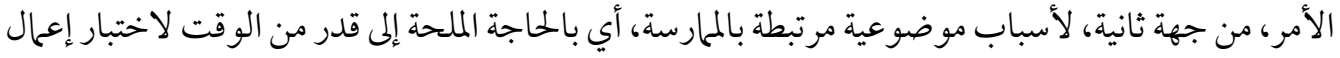

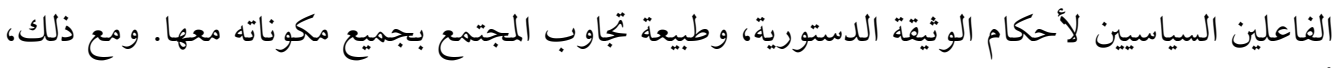

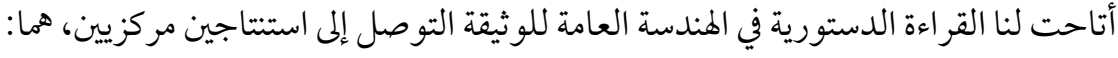

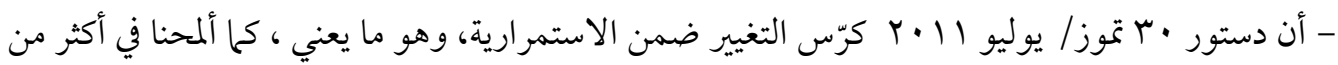

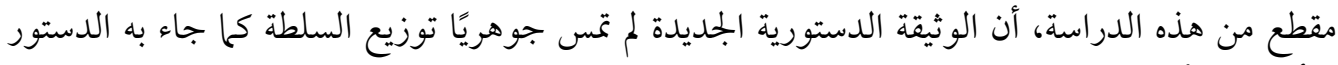

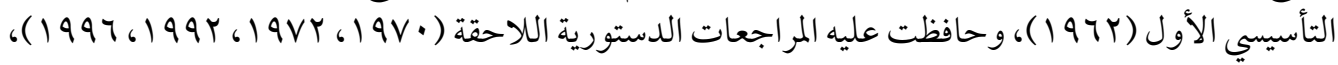

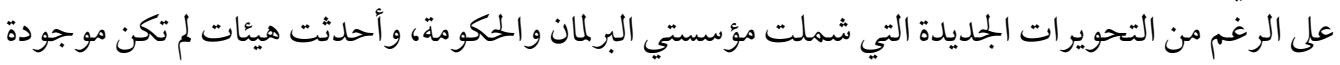

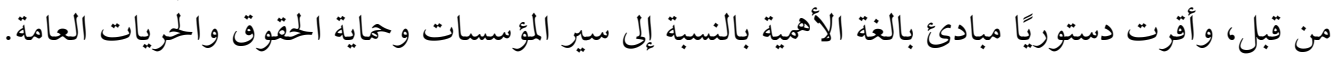

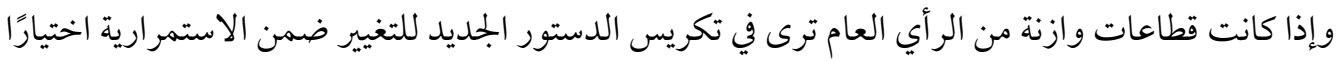

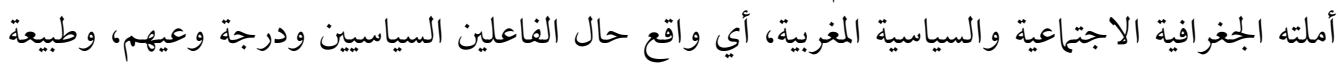

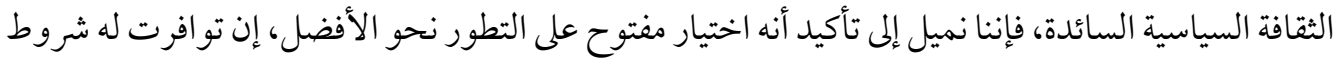

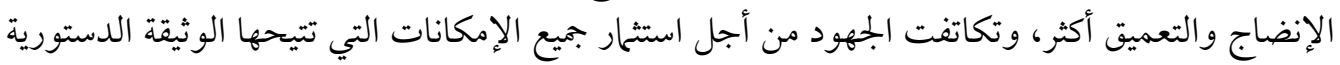

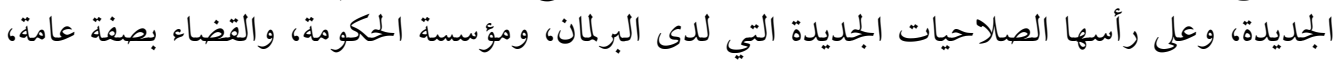
و القضاء الدستوري على وجه التحديد، وهيئات مماية حقوق الإنسان والحكامة الجانيات الجيدة.

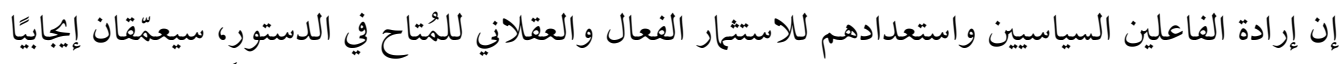

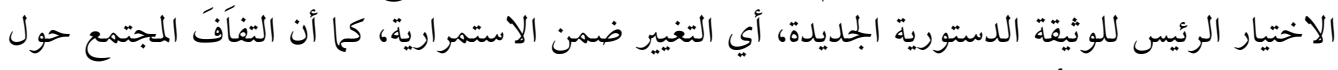

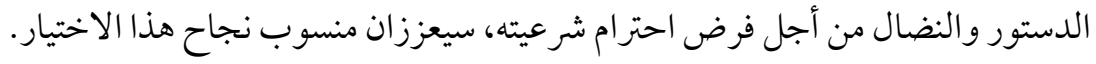


- أن جلّ المغاربة يتطلع إلى أن يكون الاستفتاء على الدستور و إقرارَه بنسبة مرتفعة عبر التصويت كخطوة أولى عالى

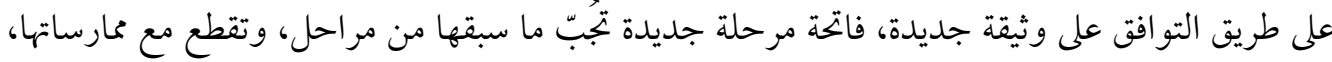

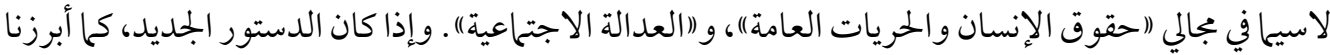

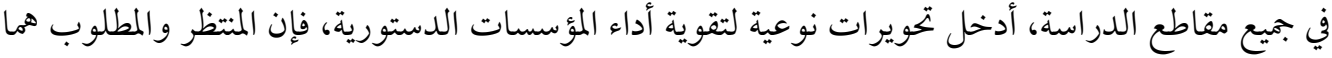

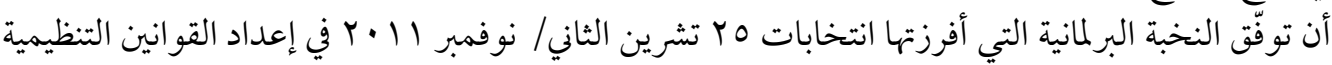

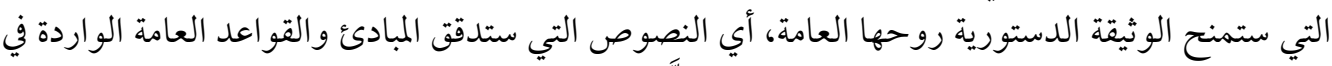

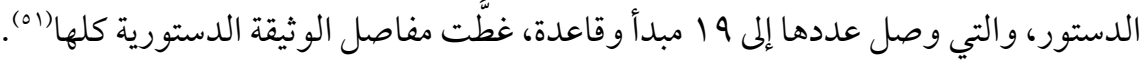

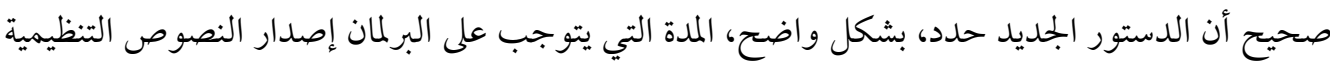

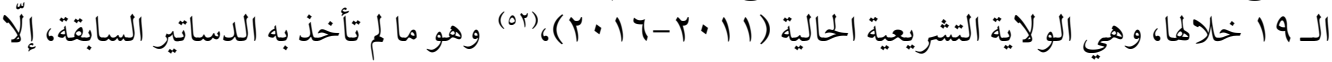

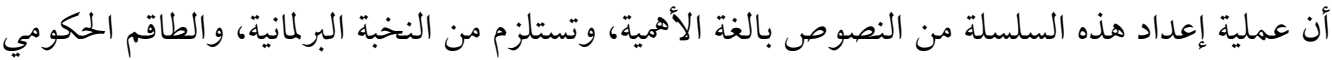

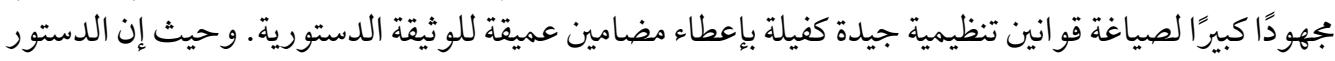

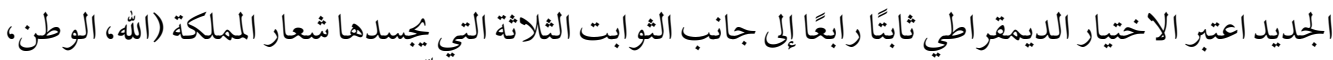

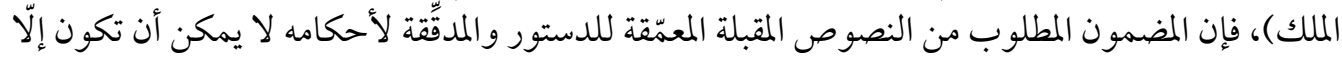

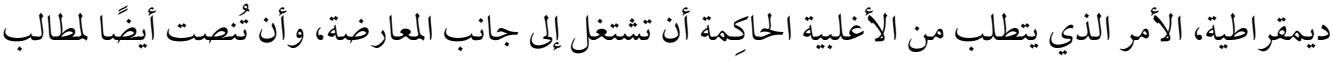

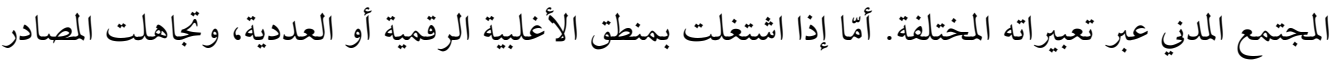

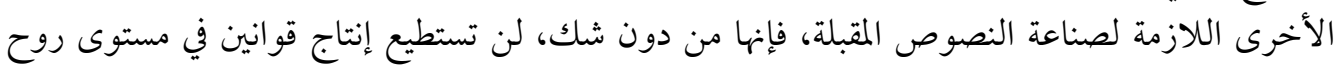

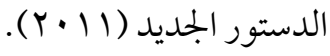

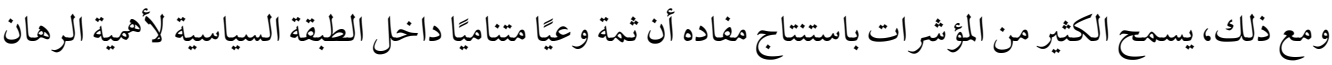

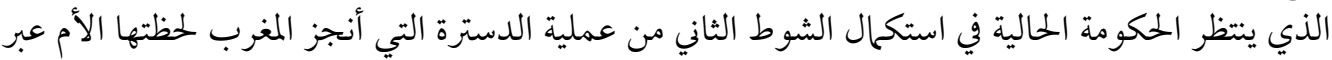

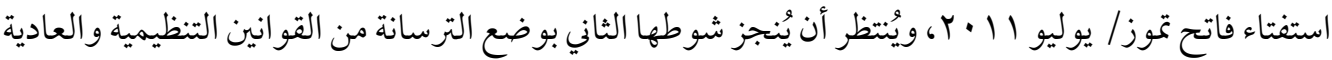

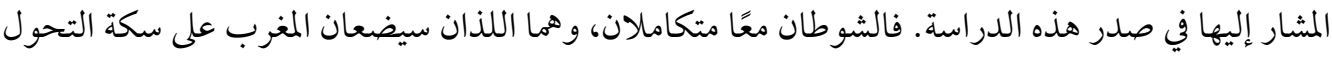

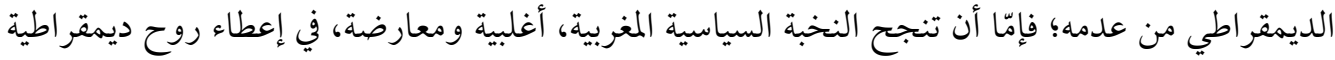

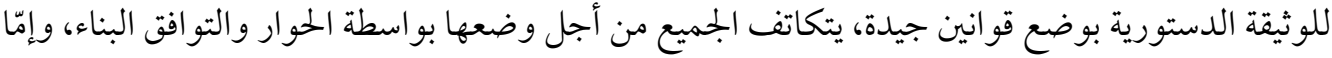

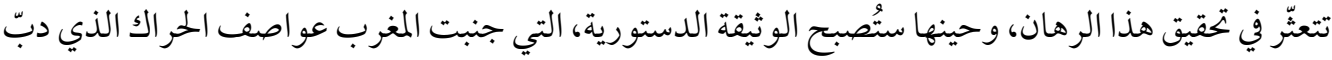

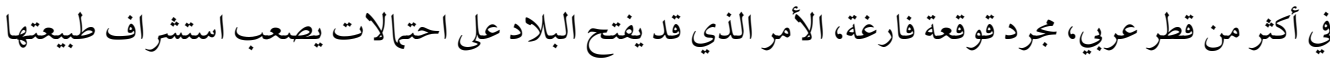
على وجه اليقين.

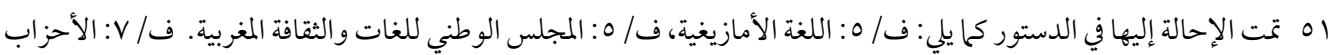

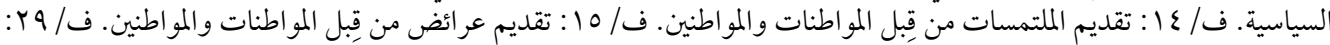

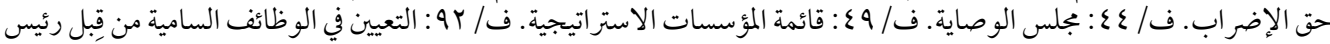

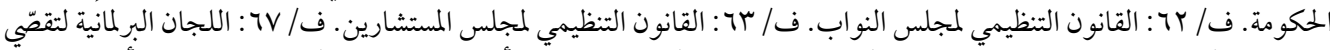

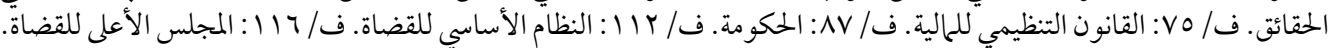

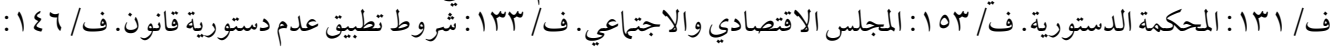
الجماعات الترابية.

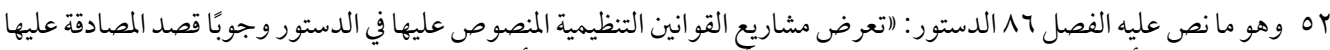

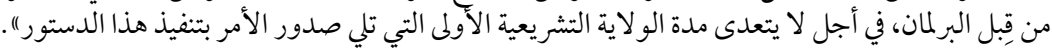




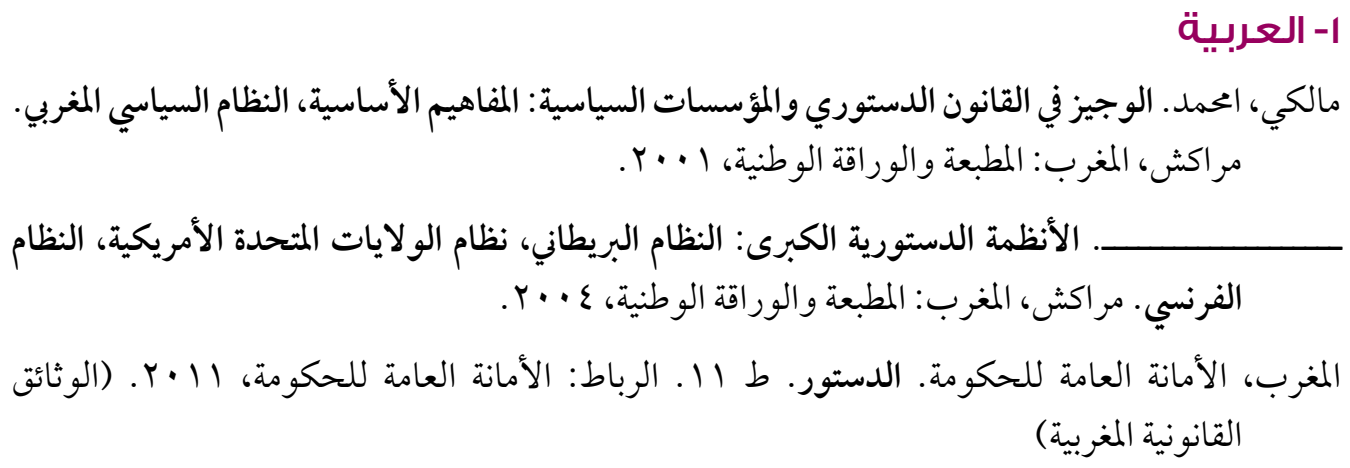

r- الأجنبية

Driss Basri [et al.]. Revision de la constitution marocaine, 1992. Rabat: [Imprimerie Royale], 1992. (Collection édification d'un état moderne)

El Mossadeq, Rkia. Acteurs politiques dans l'espace constitutionnel. Casablanca: Imprimerie Najah Al Jadida, 2011.

Hakou .Y et Elyahyaoui Y, Constitution Marocaine 2011 : nouveautés et perspectives, 225 p.

La Constitution marocaine de 2011: Analyses et commentaires. Sous la direction du Centre d'études internationales (CEI). Paris : LGDJ-Lextenso éd., 2012.

La Constitution marocaine de 2011: Lectures croisées: Actes des colloques. Organisés par le Centre Maurice Hauriou de la Faculté de droit de l'Université Paris Descartes; l'Observatoire d'études géopolitiques et la Revue marocaine d'administration locale et de développement à l'École nationale d'administration à Rabat, le 22 juin 2011 et à l'École nationale d'administration à Paris, le 30 juin 2011; [sous la direction de Ahmed Bouachik, Michel Degoffe et Charles Saint-Prot]. Rabat: Publications de la «Revue marocaine d'administration locale et de développement», 2012. (Thèmes actuels; 77)

Ruf, W. K. [et al.]. Introduction à l'Afrique du Nord contemporaine: Centre de recherches et d'études sur les sociétés méditerranéennes. Paris : Éditions du Centre national de la recherche scientifique, 1975.

Vedel, Georges, Michel Rousset et Driss Basri (dirs.).Trente années de vie constitutionnelle au Maroc. Paris: Librairie générale de droit et de jurisprudence, 1993. (Bibliothèque constitutionnelle et de science politique)

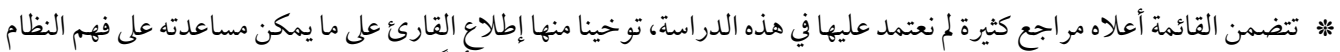

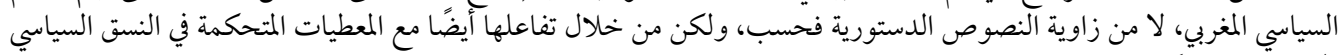
المغربي بجميع مككوناته. 